\title{
ONREL
}
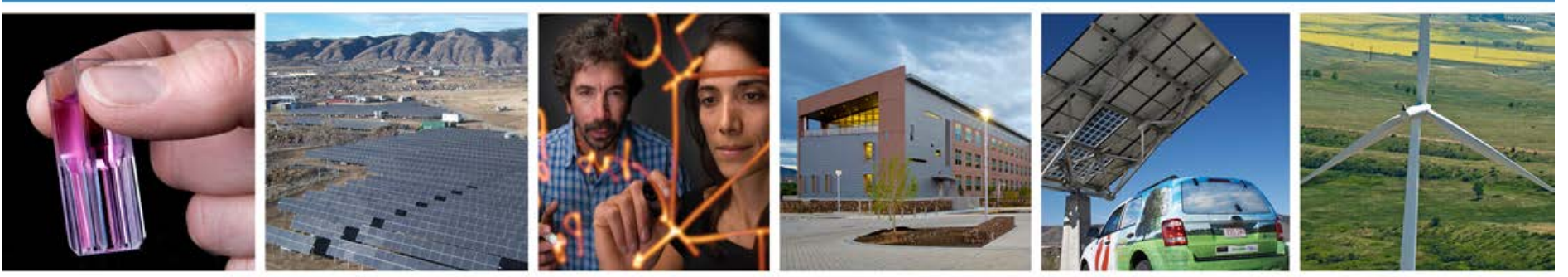

\section{Industry Research and Recommendations for New Commercial Buildings}

Bob Hendron, Matt Leach, Natalie Gregory, and Shanti Pless

National Renewable Energy Laboratory

Steve Selkowitz and Paul Matthew

Lawrence Berkeley National Laboratory

NREL is a national laboratory of the U.S. Department of Energy Office of Energy Efficiency \& Renewable Energy

Operated by the Alliance for Sustainable Energy, LLC

This report is available at no cost from the National Renewable Energy Laboratory (NREL) at www.nrel.gov/publications.

Technical Report

NREL/TP-5500-60390

May 2014

Contract No. DE-AC36-08GO28308 


\section{Industry Research and Recommendations for New Commercial Buildings}

Bob Hendron, Matt Leach, Natalie Gregory, and Shanti Pless

National Renewable Energy Laboratory

Steve Selkowitz and Paul Matthew

Lawrence Berkeley National Laboratory

Prepared under Task No. BEC8.1501

NREL is a national laboratory of the U.S. Department of Energy

Office of Energy Efficiency \& Renewable Energy

Operated by the Alliance for Sustainable Energy, LLC

This report is available at no cost from the National Renewable Energy Laboratory (NREL) at www.nrel.gov/publications.

National Renewable Energy Laboratory 15013 Denver West Parkway Golden, CO 80401

303-275-3000 • www.nrel.gov

\section{Technical Report}

NREL/TP-5500-60390

May 2014

Contract No. DE-AC36-08GO28308 


\section{NOTICE}

This report was prepared as an account of work sponsored by an agency of the United States government. Neither the United States government nor any agency thereof, nor any of their employees, makes any warranty, express or implied, or assumes any legal liability or responsibility for the accuracy, completeness, or usefulness of any information, apparatus, product, or process disclosed, or represents that its use would not infringe privately owned rights. Reference herein to any specific commercial product, process, or service by trade name, trademark, manufacturer, or otherwise does not necessarily constitute or imply its endorsement, recommendation, or favoring by the United States government or any agency thereof. The views and opinions of authors expressed herein do not necessarily state or reflect those of the United States government or any agency thereof.

This report is available at no cost from the National Renewable Energy Laboratory (NREL) at www.nrel.gov/publications.

Available electronically at http://www.osti.gov/scitech

Available for a processing fee to U.S. Department of Energy and its contractors, in paper, from:

U.S. Department of Energy

Office of Scientific and Technical Information

P.O. Box 62

Oak Ridge, TN 37831-0062

phone: 865.576 .8401

fax: 865.576.5728

email: mailto:reports@adonis.osti.gov

Available for sale to the public, in paper, from:

U.S. Department of Commerce

National Technical Information Service

5285 Port Royal Road

Springfield, VA 22161

phone: 800.553 .6847

fax: 703.605.6900

email: orders@ntis.fedworld.gov

online ordering: http://www.ntis.gov/help/ordermethods.aspx

Cover Photos: (left to right) photo by Pat Corkery, NREL 16416, photo from SunEdison, NREL 17423, photo by Pat Corkery, NREL 16560, photo by Dennis Schroeder, NREL 17613, photo by Dean Armstrong, NREL 17436, photo by Pat Corkery, NREL 17721. 


\section{Acknowledgments}

The authors thank Arah Schuur and Sonia Punjabi, of the U.S. Department of Energy (DOE) Building Technologies Office for their leadership and support of this project. The authors also thank Jeremiah Williams, Ian Lahiff, Amy Jiron, and Amir Roth from the DOE Building Technologies Office for their valuable assistance. The authors express their appreciation to Kevin Settlemyre of Sustainable IQ who assisted Lawrence Berkeley National Laboratory (LBNL), and Maureen McIntyre of McIntyre Communications Inc., who assisted NREL, for providing valuable written material and graphics used in the report. In addition, the authors thank William Livingood, Rois Langner, Paul Torcellini, Ron Judkoff, Mark Swisher, Eric Bonnema, Linh Truong, Gabrial Boeckman, Marjorie Schott, Stefanie Woodward, Kristy Usnick, Michele DeMark, and Joelynn Schroeder for their contributions to this report.

The authors also express our strong appreciation to members of the commercial new construction community who contributed ideas, recommendations, and thoughtful comments at various stages in the process:

\begin{tabular}{|c|c|c|c|}
\hline Ron Abo & The ABO Group, Inc. & Charles Klee & Payette \\
\hline Peter Alspach & Arup & Ira Krepchin & E Source \\
\hline John Andary & Integral Group & Julianne Laue & DLR Group \\
\hline Mark Bassett & Gensler & Mary Ann Lazarus & HOK \\
\hline Gary Becker & $\begin{array}{l}\text { Sacramento } \\
\text { Municipal Utility } \\
\text { District }\end{array}$ & Arlen Li & Payette \\
\hline Nick Bengston & PECI & Kathy Loftus & Whole Foods Market \\
\hline Kathia Benitez & $\begin{array}{l}\text { New York } \\
\text { Presbyterian Hospital }\end{array}$ & Andrea Love & Payette \\
\hline Aaron Binkley & Prologis & Joel Loveland & $\begin{array}{l}\text { U. Wash. Integrated } \\
\text { Design Lab }\end{array}$ \\
\hline Zorana Bosnic & $\mathrm{HOK}$ & Erin McConahey & Arup \\
\hline Benjamin Callam & Gensler & Katie Mesia & Gensler \\
\hline David Carallo & $\begin{array}{l}\text { Fitzmartin Consulting } \\
\text { Company }\end{array}$ & John Murphy & Trane Ingersoll Rand \\
\hline Rob Cassidy & $\begin{array}{l}\text { Building Design + } \\
\text { Construction }\end{array}$ & Thomas Ochtera & City of Westminster \\
\hline Eliot Crowe & PECI & Tim Peglow & $\begin{array}{l}\text { MD Anderson Cancer } \\
\text { Center }\end{array}$ \\
\hline John D’Angelo & $\begin{array}{l}\text { New York } \\
\text { Presbyterian Hospital }\end{array}$ & Mark Perepelitza & SERA Architects \\
\hline $\begin{array}{l}\text { Catherine } \\
\text { Dannenbring }\end{array}$ & Skanska & Lisa Petterson & SERA Architects \\
\hline
\end{tabular}




\begin{tabular}{|c|c|c|c|}
\hline Michele Davison & $\begin{array}{l}\text { Colorado Energy } \\
\text { Office }\end{array}$ & John Priebe & The ABO Group, Inc. \\
\hline Laura Debonis & Gensler & John Pulley & Buro Happold \\
\hline Jennifer Elling & Excel Energy & Teresa Rainey & $\begin{array}{l}\text { Skidmore, Owings \& } \\
\text { Merrill LLP }\end{array}$ \\
\hline Mike Ellinger & Whole Foods Market & Suzanne Robinson & Vanderweil Engineers \\
\hline Don Fitzmartin & $\begin{array}{l}\text { Fitzmartin Consulting } \\
\text { Company }\end{array}$ & Cindy Strecker & PECI \\
\hline Bruce Fowle & FXFowle & Prem Sundharam & DLR Group \\
\hline Scott Frank & $\mathrm{JB} \& \mathrm{~B}$ & Bill Talbert & $\begin{array}{l}\text { Affiliated Engineers, } \\
\text { Inc. }\end{array}$ \\
\hline Angie Fyfe & $\begin{array}{l}\text { USGBC Colorado } \\
\text { Chapter }\end{array}$ & Wayne Thalasinos & $\begin{array}{l}\text { National Aeronautics } \\
\text { and Space } \\
\text { Administration }\end{array}$ \\
\hline Tim Gaidis & HOK & Michael Tillou & Atelier Ten \\
\hline $\begin{array}{l}\text { Michael } \\
\text { Hinchcliffe }\end{array}$ & Payette & Peter Turnbull & Pacific Gas \& Electric \\
\hline Don Horn & GSA & Kate Turpin & SERA Architects \\
\hline Tom Hootman & RNL Design & Clayton Ulrich & Hines \\
\hline Roger Hubert & $\begin{array}{l}\text { Trane Commercial } \\
\text { Systems }\end{array}$ & Martin Weiland & GSA \\
\hline John Jennings & $\begin{array}{l}\text { Northwest Energy } \\
\text { Efficiency Alliance }\end{array}$ & Phil Williams & Webcor \\
\hline David Johnson & CO Architects & Scott Williams & Target \\
\hline Ilana Judah & FXFowle & Chad Wisler & Vanderweil Engineers \\
\hline Shruti Kasarekar & Atelier Ten & Kevin Yoshida & The ABO Group, Inc. \\
\hline Mike Keesee & $\begin{array}{l}\text { Sacramento } \\
\text { Municipal Utility } \\
\text { District }\end{array}$ & Corey Zarecki & $\begin{array}{l}\text { Gundersen Lutheran } \\
\text { Health System }\end{array}$ \\
\hline Nico Kienzl & Atelier Ten & & \\
\hline
\end{tabular}

Many other stakeholders provided input to previous roadmaps, action plans, and policy documents, which were relied on heavily in defining the priorities in this report. These contributors are too numerous to list, but can be found in the original documents cited in the reference list. 


\section{Nomenclature}

\begin{tabular}{|c|c|}
\hline AECO & architecture, engineering, construction, and owner/operator \\
\hline AEDG & Advanced Energy Design Guide \\
\hline AHRI & Air-Conditioning, Heating, and Refrigeration Institute \\
\hline AIA & American Institute of Architects \\
\hline BBA & Better Buildings Alliance \\
\hline BOMA & Building Owners and Managers Association \\
\hline BTO & Building Technologies Office \\
\hline Btu & British thermal unit \\
\hline CBECS & Commercial Buildings Energy Consumption Survey \\
\hline CBI & Commercial Building Integration \\
\hline СВP & Commercial Buildings Partnership \\
\hline $\mathrm{cfm}$ & cubic feet per minute \\
\hline COMNET & Commercial Energy Services Network \\
\hline DOE & U.S. Department of Energy \\
\hline EIA & Energy Information Administration \\
\hline EISA & Energy Independence and Security Act \\
\hline EPA & U.S. Environmental Protection Agency \\
\hline ET & Emerging Technologies Program \\
\hline EUI & energy use intensity \\
\hline FEMP & Federal Energy Management Program \\
\hline $\mathrm{ft}$ & foot \\
\hline $\mathrm{ft}^{2}$ & square foot \\
\hline GSA & U.S. General Services Administration \\
\hline GSEP & Global Superior Energy Performance (Partnership) \\
\hline HVAC & heating, ventilation, and air-conditioning \\
\hline ICC & International Code Council \\
\hline $\mathrm{kW}$ & kilowatt \\
\hline LBNL & Lawrence Berkeley National Laboratory \\
\hline $\mathrm{M} \& \mathrm{~V}$ & measurement and verification \\
\hline NASEO & National Association of State Energy Officials \\
\hline NBI & New Buildings Institute \\
\hline NREL & National Renewable Energy Laboratory \\
\hline NZE & net-zero energy \\
\hline NZER & net-zero energy ready \\
\hline $\mathrm{O} \& \mathrm{M}$ & operations and maintenance \\
\hline PV & photovoltaic \\
\hline quad & quadrillion Btu \\
\hline SEE Action & State and Local Energy Efficiency Action Network \\
\hline SEED & Standard Energy Efficiency Data (Platform) \\
\hline TLCC & total life cycle cost \\
\hline USGBC & U.S. Green Building Council \\
\hline $\mathrm{W}$ & Watt \\
\hline WIP & Weatherization and Intergovernmental Program \\
\hline
\end{tabular}




\section{Executive Summary}

For some time, the U.S. Department of Energy (DOE) has developed and deployed resources, methods, tools, and technologies that advance the design and construction of high performance and net-zero energy (NZE) commercial buildings. Although many principles of high performance buildings are well understood, uptake in the marketplace has been limited and riddled with real and perceived barriers, technical roadblocks, and financial constraints.

Broad implementation of high performance buildings is likely to require an integrated approach that accelerates the adoption of energy efficiency technologies and whole-building design principles by leveraging DOE expertise and resources as well as building new partnerships and enhancing existing relationships between key public and private sector stakeholders.

Toward this end, the authors evaluated industry needs and developed logic models to support possible future commercial new construction research and deployment efforts that could be led or supported by DOE's Commercial Building Integration program or other national initiatives. The authors believe that these recommendations support a proposed course of action from the current state of commercial building energy efficiency to a possible long-term goal of achieving significant market penetration of cost-effective NZE buildings in all building sectors and climates by 2030. These recommendations emphasize the energy efficiency component of NZE, or net-zero energy ready (NZER) buildings.

Several definitions are useful for clarifying the proposed goal:

- NZER: A building that includes all efficiency measures that are more cost effective than renewable energy

- NZE: A building that generates as much source energy using renewable energy sources as it consumes on an annual basis, and complies with one or more of the class definitions in Pless and Torcellini (2010)

- Cost-effective NZE: A building that meets the definition of NZE with a life cycle cost below ASHRAE 90.1-2010 when renewable generation is added.

The overall development process for the recommendations in this report is illustrated in Figure ES-1.

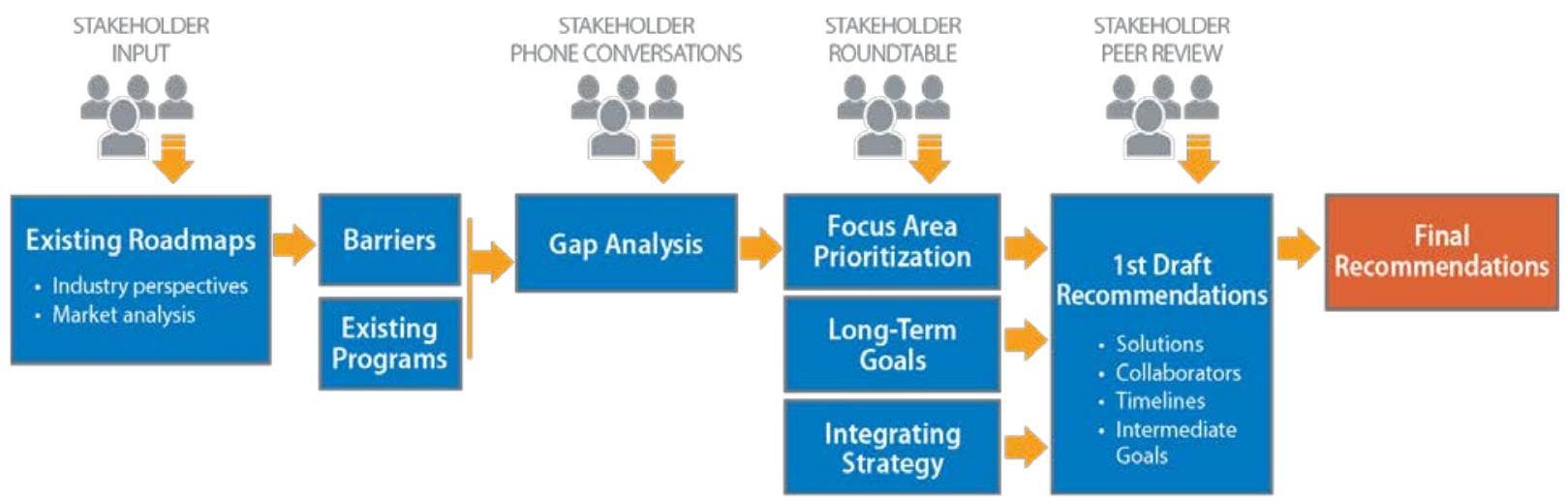

Figure ES-1 Overall process for developing the recommendations in this report 
The process began with a review of 21 new construction roadmaps, action plans, market analyses, technology analyses, and policy documents developed by diverse organizations in government and industry, and with inputs from a large cross-section of stakeholders. Several conclusions were drawn from this review:

- Existing roadmaps provide extensive analysis of technical and market barriers, and recommendations for key market sectors and deployment vehicles.

- Several market analyses address the current and future states of the commercial new construction industry, including trends toward high performance.

- Many roadmaps establish multiyear targets for industry that are consistent with the goals of the 2007 Energy Independence and Security Act, which calls for NZE new commercial buildings to be economically viable by 2030 , for half the commercial building stock to be NZE by 2040, and for all commercial buildings to be NZE by 2050 .

- The literature defines NZE in various ways. Many definitions require sufficient roofmounted photovoltaics (PV) to meet the annual energy needs of a building; many others allow alternative methods of accounting for renewables (on-site PV, off-site PV, city block or community scale, renewable energy credits, NZE capable, or NZER with no explicit requirement for PV). Each definition has significant technical (e.g., site access) and financial (e.g., first cost) implications.

A high-level gap analysis was conducted to identify development, demonstration, and deployment opportunities that would address underserved industry needs at a national level. The process included:

- A comparison of the objectives of current DOE programs with barriers already identified in existing roadmaps, based on material publicly available through program websites. A forward-looking review of the research agendas for current DOE programs was not performed, nor was an objective evaluation of the effectiveness of these programs.

- Phone conversations with more than 50 stakeholders

- A roundtable meeting with 23 stakeholders

- Two webinars with building owners and real estate developers.

The gap analysis process resulted in the following five recommended high priority focus areas and key near-term strategies that could be pursued as part of an integrated federal effort:

1. Energy benchmark data. System and whole-building level energy benchmark data, organized by building type and climate, which can be used for setting performance targets for new buildings.

- Define normalization methods and metrics that address building use, size, and other energy drivers.

- Create analysis-based whole-building benchmarks by climate zone and building type, normalized as appropriate.

- Establish analysis-based whole-building targets for high performance and NZER buildings. 
- Define end-use level targets consistent with whole-building targets.

- Leverage Portfolio Manager and the Building Performance Database to gather a statistically significant set of high performance new construction benchmark data.

2. Enhanced modeling tools. Improved modeling tools to support financial decisionmaking, whole-building design, analysis of new technologies, model calibration, and identification of operational and behavioral influences on energy use throughout the building life cycle.

- Provide efficiency package optimization capability.

- Develop better early stage design tools, such as using heuristic-based analysis derived from large-scale simulations of efficiency perturbations individually and in combination. .

- Develop prepackaged optimized design solutions for small businesses.

- Conduct a study of user interface needs for diverse audiences and applications, and customize user interfaces for those audiences.

- Perform laboratory and field testing of high performance building equipment and complex systems to improve modeling algorithm accuracy.

3. Better cost data. Objective, vetted average component- and system-level cost data for analysis of return on investment.

- Perform an assessment of industry cost data workflows.

- Identify cost data parameters that influence design decisions.

- Establish a cost estimation procedure that systematically accounts for system interactions and tradeoffs.

- Develop a clear business case for community-based cost data collection to motivate building owners; architecture, engineering, construction, and owner/operations (AECO) companies; equipment manufacturers; and equipment vendors to supply cost information to a public database.

- Expand partnerships for cost data collection and maintenance.

- Create a publicly accessible cost database that facilitates early design decisionmaking, or support enhancements to existing databases to include cost data.

4. Commissioning and operational strategies. Effective commissioning and operational methods, technologies, and tools, demonstrated through case studies.

- Improve project delivery methods to better ensure that high performance buildings meet specified targets.

- Study the nature and magnitude of commissioning and operating failures that cause buildings to perform below expectations.

- Document best practices for commissioning, operating, and maintaining advanced systems and technologies in high performance buildings. 
- Develop educational materials for building occupants about the features of high performance buildings and simple things they can do to help such buildings perform optimally.

- Identify robust design strategies, self-diagnostic capabilities, and automated fault detection techniques that mitigate the impact of operational deficiencies.

5. Integrated resources. Resources that include new construction case studies, best practice guides, datasets, and tools in a more accessible, adaptable, and user-friendly format:

- Evaluate current federal resource integration practices to determine opportunities for improved delivery of information.

- Create a workflow specification and resource taxonomy that allows all available resources to be filtered according to project parameters and intended audience.

- Establish the requirements of a centralized gateway for resources that would enable users to find the information they need in one place.

- Document case studies that emphasize cost and performance details, and use additional analysis to expand the applicability of the relevant design and construction strategies to a wider range of project parameters.

This report describes key activities and collaborations in each focus area that the authors believe can overcome the major barriers and lead to innovation and more rapid market acceptance of NZE commercial buildings. In addition, this report includes recommended long-term efficiency and deployment goals and possible integrating strategies for leveraging existing programs and coordinating new initiatives to produce the greatest impact. This report focuses on three stages of the market transformation process: (1) development, (2) demonstration, and (3) deployment. Completion of each stage can be validated using a stage-gate process with specific go/no-go criteria and metrics. Certain commercial building types, such as non-refrigerated warehouses, may be ready for deployment immediately; others may require several years of effort to develop cost-effective measures and improved technical approaches. 


\section{Table of Contents}

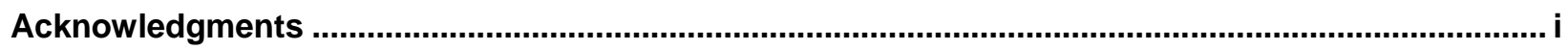

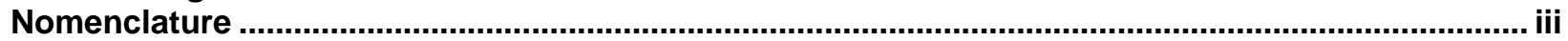

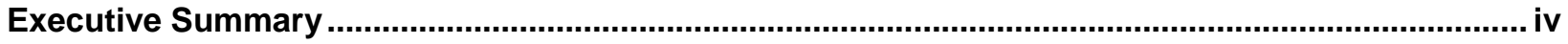

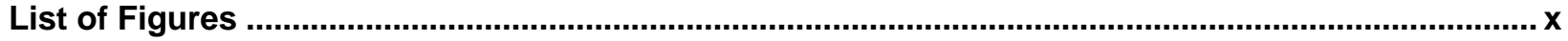

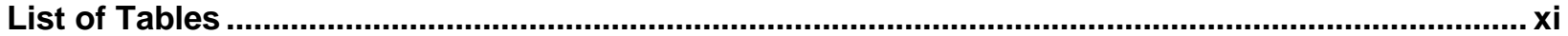

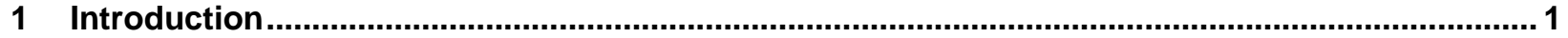

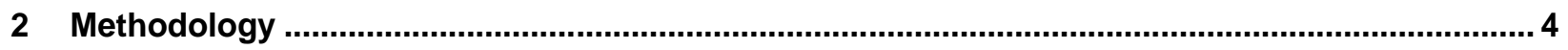

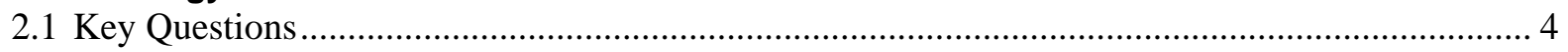

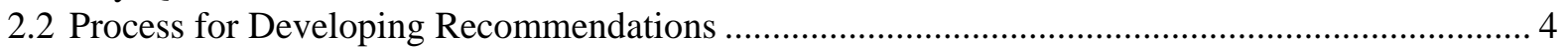

2.3 Existing Resources................................................................................................................ 5

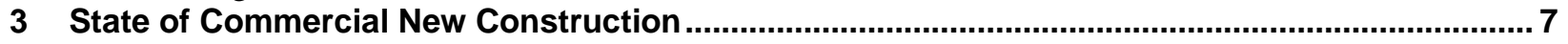

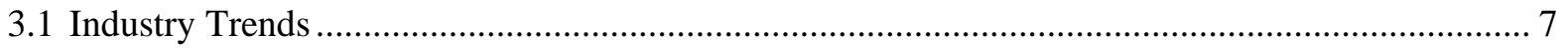

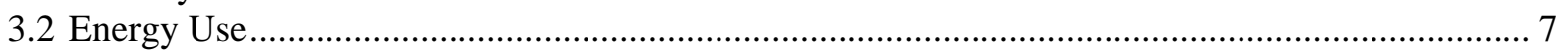

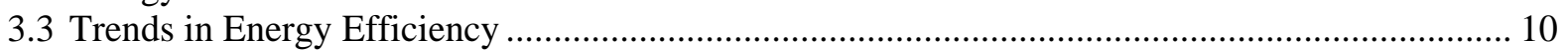

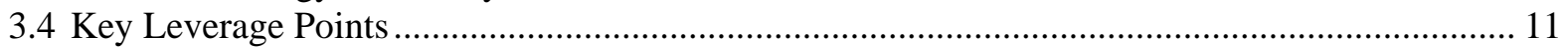

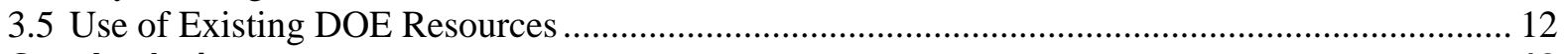

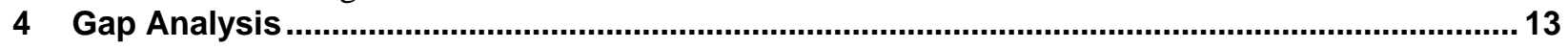

4.1 Results of Approach \#1: Analysis of Barriers and Existing DOE Programs ............................... 13

4.2 Results of Approach \#2: Industry Stakeholder Conversations .................................................... 14

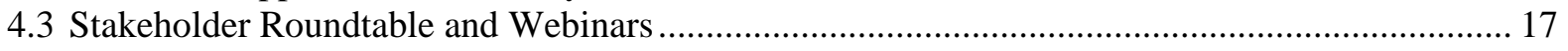

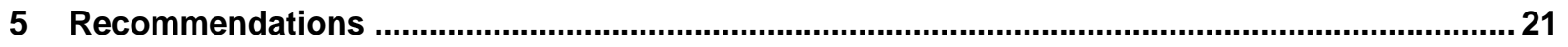

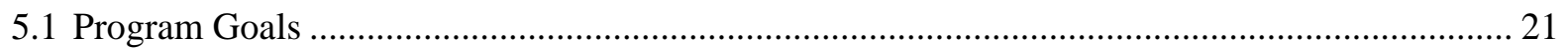

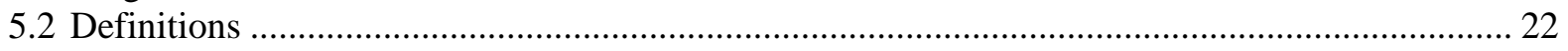

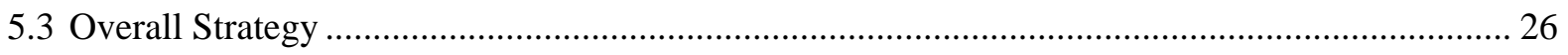

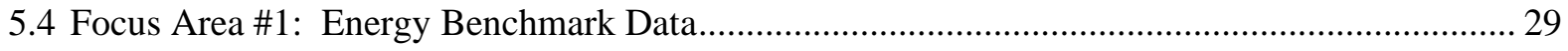

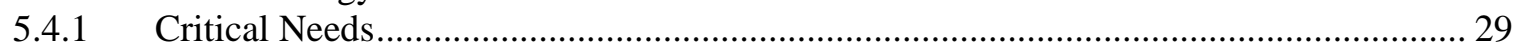

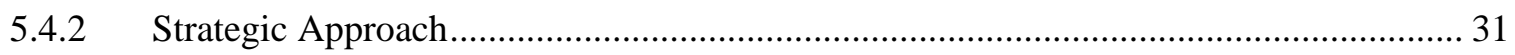

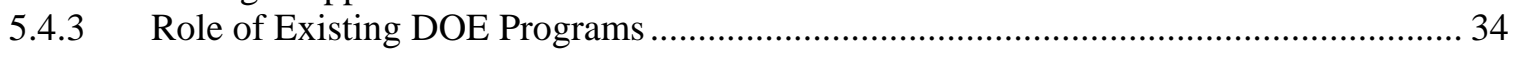

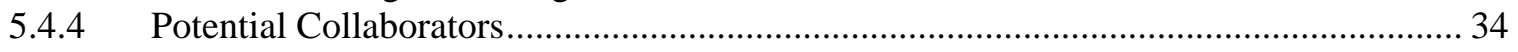

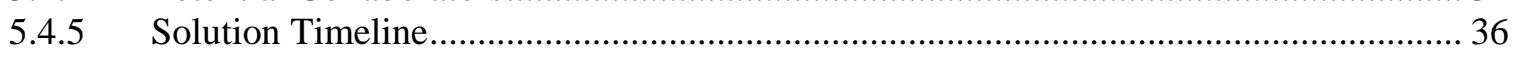

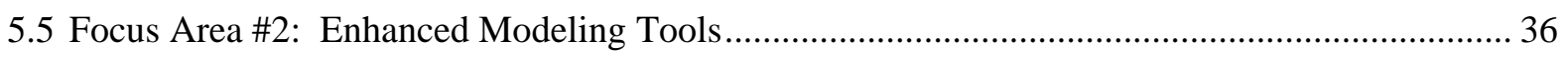

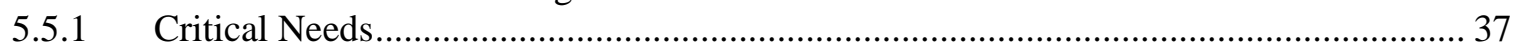

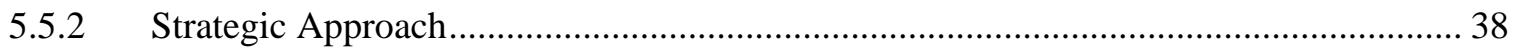

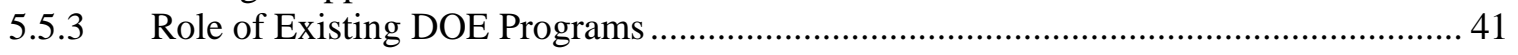

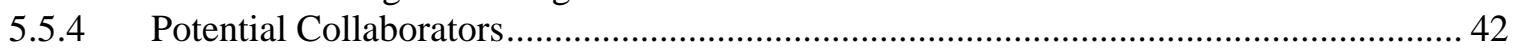

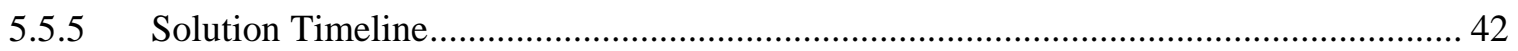

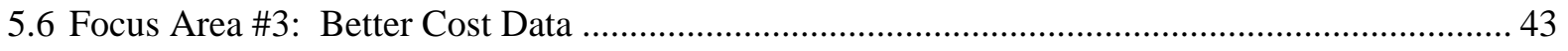

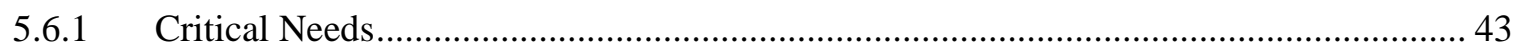

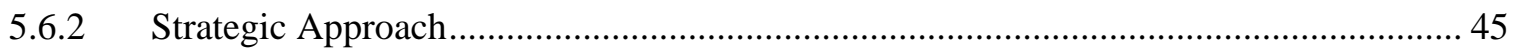

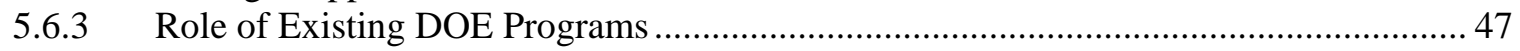

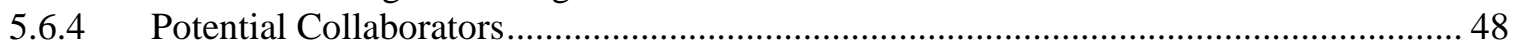

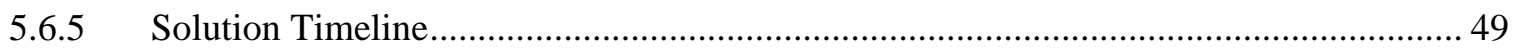

5.7 Focus Area \#4: Commissioning and Operational Strategies.................................................... 49

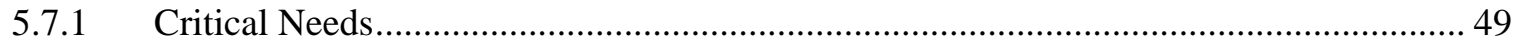

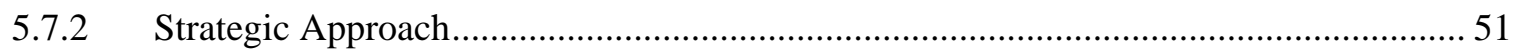

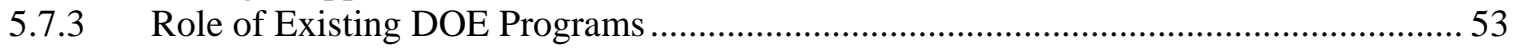

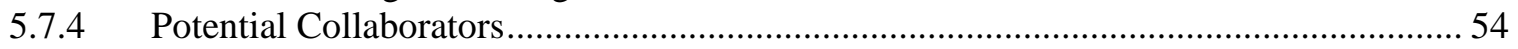

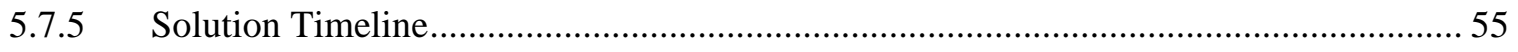

5.8 Focus Area \#5: Integrated Resources..................................................................................... 55

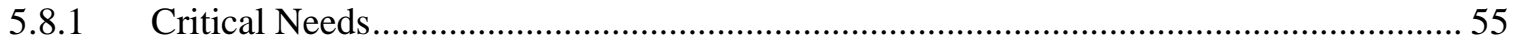




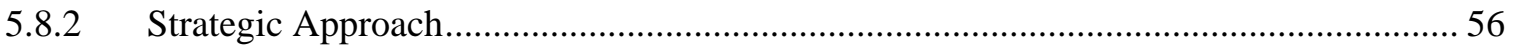

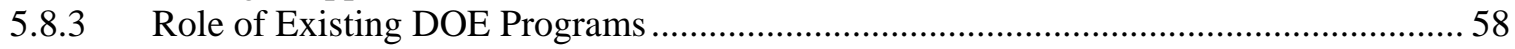

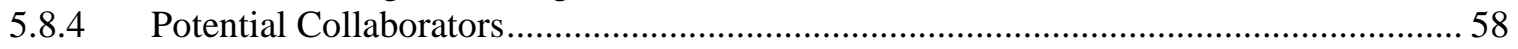

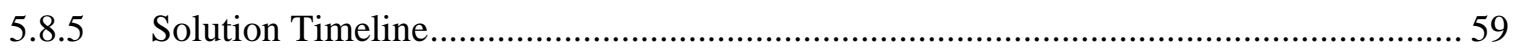

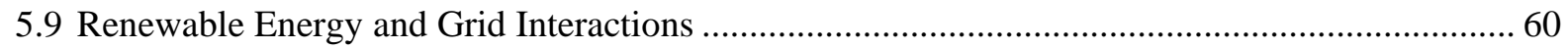

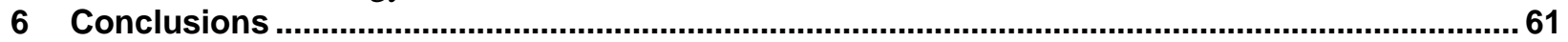

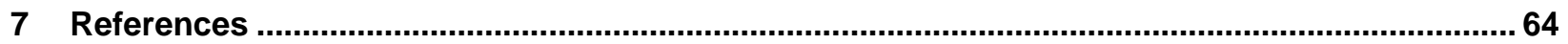

Appendix A: Roadmaps, Policy Studies, and Market Analyses Used To Guide

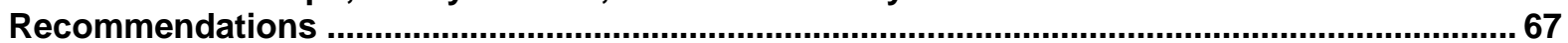

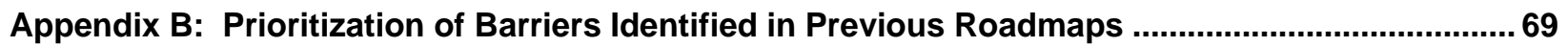




\section{List of Figures}

Figure ES-1 Overall process for developing the recommendations in this report....................... iv

Figure 1-1 DOE programs that may support or be supported by $C B I$ in the execution of new construction research and deployment priorities ................................................................ 2

Figure 2-1 Process for developing the recommendations in this report.......................................5

Figure 2-2 Categories of stakeholders consulted throughout the process ................................5

Figure 3-1 Recent and projected construction trends in the United States (\$ billion)................... 7

Figure 3-2 Energy use trends for commercial buildings.......................................................... 8

Figure 3-3 Source energy breakdown by end use in commercial buildings, 2012...................... 10

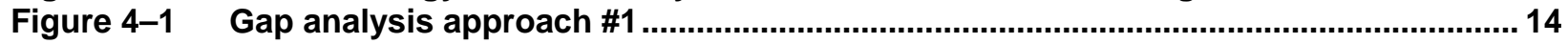

Figure 5-1 United States climate zones used in ASHRAE 90.1 (Briggs et al. 2003) ....................22

Figure 5-2 NZE and NZER in context of optimal life cycle cost curve ......................................2 24

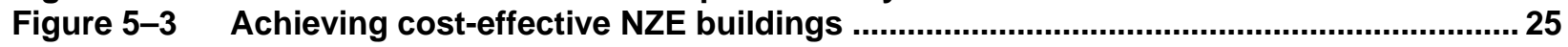

Figure 5-4 Recommended new construction stage-gate criteria .............................................. 26

Figure 5-5 Example stage-gate timelines for different commercial building types......................27

Figure 5-6 Proposed classification system for new construction solutions ................................28

Figure 5-7 Projected impacts of solution classes at various construction stages ..................... 29

Figure 5-8 Linking critical energy benchmarking needs to audience and impact........................30

Figure 5-9 Dimensions of energy benchmark data needed for effective target setting...............31

Figure 5-10 Proposed energy benchmark data solution timeline ............................................... 36

Figure 5-11 Linking critical energy modeling needs to audience and impact ............................37

Figure 5-12 Four categories of $\mathrm{CBI}$ support for modeling tool engines developed by the

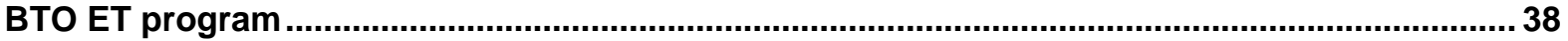

Figure 5-13 Proposed enhanced modeling tool solution timeline ............................................ 43

Figure 5-14 Linking critical cost data needs to audience and impact .......................................45

Figure 5-15 Proposed cost data solution timeline ............................................................... 49

Figure 5-16 Linking critical operational needs to audience and impact......................................50

Figure 5-17 Possible commissioning and operational strategy solution timeline .....................55

Figure 5-18 Linking critical integrated resource needs to audience and impact ......................56

Figure 5-19 Possible integrated resource solution timeline .....................................................59 


\section{List of Tables}

Table 3-1 Energy Use Characteristics of the 16 CBECS Building Sectors ................................... 9

Table 4-1 Research and Deployment Gaps Identified Using Approach \#1................................ 14

Table 4-2 Perceived Research and Deployment Gaps Identified through Stakeholder

Conversations (Approach \#2) ....................................................................................... 17

Table 5-1 Energy Performance Metrics Commonly Used by Building Owners ........................32

Table 5-2 Energy Performance Metrics That Reflect Societal Impacts......................................... 33

Table 5-3 Classification of Proposed Solutions to Energy Benchmarking Challenges ............. 33

Table 5-4 Potential Key Collaborators for Energy Benchmark Data Solutions............................ 35

Table 5-5 Classification of Possible Solutions to Modeling Tool Challenges.............................41

Table 5-6 Potential Key Collaborators for Enhanced Modeling Tool Solutions.........................42

Table 5-7 Classification of Possible Solutions to Cost Data Challenges .................................47

Table 5-8 Potential Key Collaborators for Cost Data Solutions.................................................48

Table 5-9 Classification of Possible Solutions to Commissioning and Operational

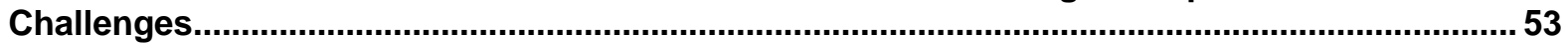

Table 5-10 Potential Key Collaborators for Commissioning and Operational Solutions ...............54

Table 5-11 Classification of Possible Solutions to Integrated Resource Challenges .................. 58

Table 5-12 Potential Key Collaborators for Integrated Resource Solutions...............................59

Table A-1 Publications Used To Guide the Recommendations in This Report .........................6 67

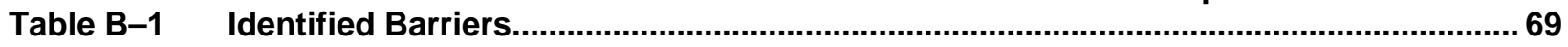




\section{Introduction}

For some time, the U.S. Department of Energy (DOE) has developed and deployed resources, methods, tools, and technologies that advance the design and construction of high performance and net-zero energy (NZE) commercial buildings. Although many principles are well understood, uptake in the marketplace has been limited and riddled with real and perceived barriers, technical roadblocks, and financial constraints. A combination of solutions that address technical, educational, and cost barriers is needed to sustain long-term advancements in building energy performance.

Broad implementation of high performance buildings can be realized using an integrated and tiered approach that accelerates the adoption of energy efficiency technologies, whole-building design principles, and collaboration between builders, designers, and owners during the construction process. This can be achieved by leveraging existing expertise and programs, building new partnerships, and enhancing relationships with key public and private stakeholders.

Toward this end, the authors endeavored to define a possible logic model for prioritizing and coordinating DOE's portfolio of commercial new construction research and deployment activities that are either led or strongly supported by the Commercial Buildings Integration (CBI) Program. The recommendations would chart a course from the current state of commercial building energy efficiency, through a series of intermediate objectives that gradually improve the average performance of new commercial buildings, and ultimately to the long-term goal of initiating broad deployment of cost-effective NZE buildings in all building sectors and climates by 2030 .

In formulating this goal, the 2007 Energy Independence and Security Act (EISA) goal was chosen as a key point of reference. EISA calls for NZE new commercial buildings to be economically viable by 2030, half the commercial building stock to be NZE by 2040, and all commercial buildings to be NZE by 2050. It was deemed important for any proposed new construction research and deployment goals to be supportive of the EISA goals.

To ensure that the proposed activities provide real value in the marketplace, a diverse set of industry stakeholders was invited to suggest new or enhanced activities that DOE could undertake to encourage greater emphasis on energy efficiency in the new commercial buildings market. Involving key stakeholders in shaping the recommendations in this report is more likely to result in a substantial industry commitment to partnering with DOE to achieve program goals.

Key elements of this report include a strategic foundation, multiyear program goals, definitions of essential roles, and collaborative opportunities between DOE's CBI program and key industry and government partners. It also recommends metrics and processes for tracking program success, including stage-gate criteria.

The recommendations center on focusing, integrating, and enhancing CBI's portfolio of projects and aligning that portfolio to related Building Technologies Office (BTO) initiatives, as well as other DOE, government, public, and private energy efficiency efforts in new commercial buildings. Necessary collaborations with other BTO programs (including Emerging Technologies, Residential Building Integration, Building Energy Codes, and Appliance Standards) are acknowledged, but prioritizing activities for those programs was not the intent of 
this project. The same is true for other DOE buildings-related programs such as the Federal Energy Management Program (FEMP), the Weatherization and Intergovernmental Program (WIP), and the Energy Information Administration (EIA).

The recommendations in this report are intended to leverage active DOE programs, and identify ways that DOE or other organizations can fill in gaps between those programs. They also address possible improvements to the integration of research and deployment efforts for new commercial buildings so BTO can move forward with a comprehensive and effective program. This report does not recommend replacing or displacing current programs. The intent of this report is to provide suggestions on broad new activity areas that might impact the development, demonstration, and deployment of high-performance buildings. For example, this report does not address building energy codes due to the depth of existing literature and well-established processes for developing and maintaining codes. Instead the report focuses on emerging opportunities in the commercial new construction market. Many DOE programs have developed, or are in the process of developing, their own roadmaps and multiyear plans. It is not the intent of this report to supplant or supersede those plans, but simply to highlight research areas where more active collaboration with CBI would be beneficial.

Figure 1-1 illustrates the relationship between CBI and other DOE programs that support energy efficiency in new commercial buildings. Emerging Technologies and FEMP will be especially important DOE programs in relation to the activities discussed in this report.

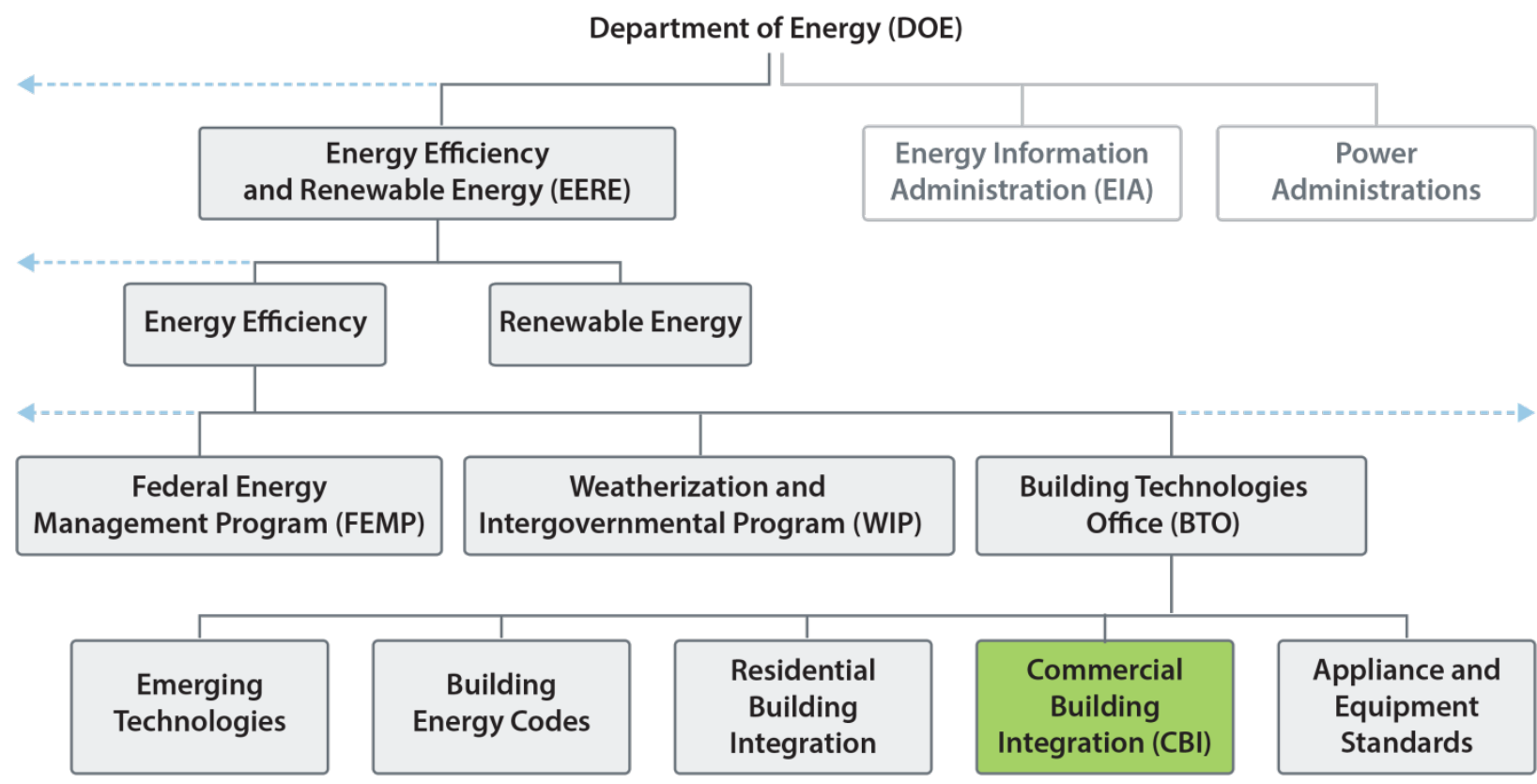

Figure 1-1 DOE programs that may support or be supported by $\mathrm{CBI}$ in the execution of new construction research and deployment priorities

Collaborating with organizations beyond DOE may be needed to achieve program goals, minimize overall costs, and reduce duplication of effort. However, recommendations are not 
made for the focus areas of organizations other than DOE, except where the success of DOE's programs are likely to depend on support from, or partnership with, outside organizations.

This report embodies the recommendations of its authors, representing the National Renewable Energy Laboratory (NREL) and Lawrence Berkeley National Laboratory (LBNL), with extensive input from industry stakeholders. It may not represent DOE's specific goals, priorities, and planned research and deployment activities. 


\section{Methodology}

The methodology used to develop this report leveraged available resources to the extent possible, and supplemented those resources with additional analysis and targeted stakeholder inputs. Three major tasks summarize the process:

Task 1: Initial scoping and understanding the landscape

Task 2: Gap analysis and stakeholder consultations

Task 3: Formulation of recommended strategies

\subsection{Key Questions}

Several key foundational questions were addressed as part of this approach:

1. What is the current state of the commercial new construction industry?

2. What energy savings targets are appropriate for new construction?

3. How could the targets be framed?

4. Which steps might industry take to achieve those targets?

5. What are the critical leverage points in the construction process?

6. What are the industry's highest priority technology and deployment barriers?

7. What might be DOE's central role?

8. What are the complementary roles of the national laboratories, state and local governments, utilities, industry associations, trade organizations, and other essential collaborators?

9. Which high priority markets could DOE target?

10. What might be the key audiences for DOE resources and products?

11. Which deployment vehicles could be emphasized?

\subsection{Process for Developing Recommendations}

A multistep process emphasizing stakeholder input was used to answer these questions (see Figure 2-1), many of which were adequately addressed by existing roadmaps. The remaining questions were addressed through a review of the published information about current DOE programs and direct interactions with key stakeholders. These questions related primarily to possible DOE roles in support of the broad implementation of NZE buildings and to key solutions that DOE can provide in the near and long terms to fulfill those roles. Stakeholder input and peer reviews at several points helped increase the likelihood that the recommended activities would target the industry's most pressing needs and provide the greatest impact for taxpayer dollars spent. Stakeholders represented a variety of perspectives from industry, academia, and government (see Figure 2-2). 


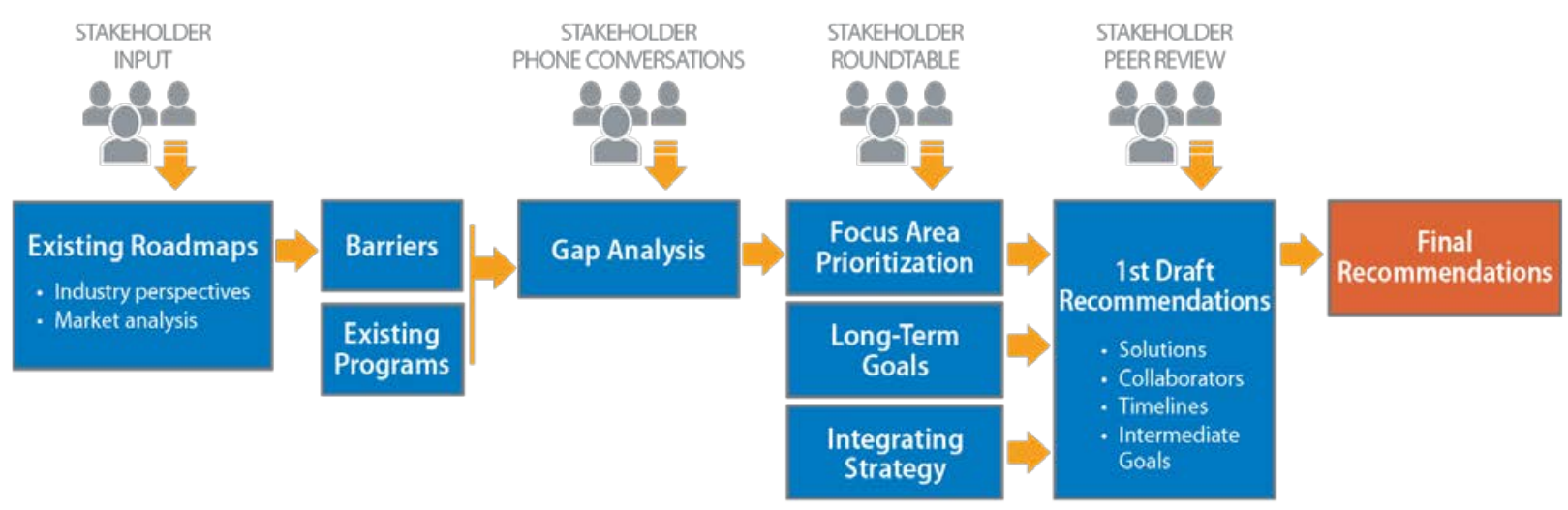

Figure 2-1 Process for developing the recommendations in this report

KEY STAKEHOLDERS

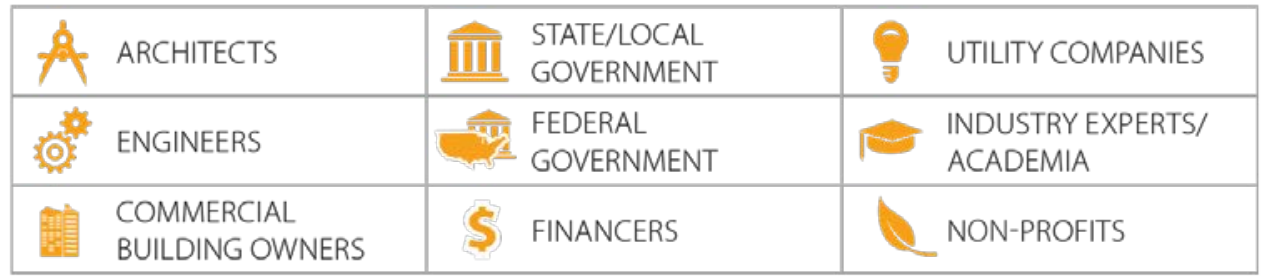

Figure 2-2 Categories of stakeholders consulted throughout the process

\subsection{Existing Resources}

Information and insights were gathered from 21 new construction roadmaps, action plans, market analyses, technology analyses, and policy documents (henceforth referred to generically as roadmaps) developed by various stakeholders in government and industry. These roadmaps were analyzed to determine which research questions (see Section 2.1) have already been answered. The recentness, audience, and degree of industry participation were considered when selecting roadmaps for inclusion in the study. Several conclusions were drawn from the existing roadmap review:

- Existing roadmaps provide extensive analysis of technical and market barriers, and recommendations for key market sectors and deployment vehicles.

- Several market analyses address the current and future states of the commercial new construction industry, including trends toward high performance.

- Many roadmaps establish multiyear targets for industry that are consistent with EISA 2007 goals.

- The roadmaps contain very little commentary on DOE's essential role or specific solutions DOE could pursue.

- The literature defines NZE in various ways. Many definitions require sufficient roofmounted photovoltaics (PV) to meet the annual energy needs of a building; many others 
allow alternative methods of accounting for renewables (on-site PV, off-site PV, city block or community scale, renewable energy credits, NZE capable, or NZER with no explicit requirement for PV). Each definition has significant technical (e.g., site access) and financial (e.g., first cost) implications.

Recommendations and information from the existing roadmaps were relied on heavily in the development of this report. Appendix A lists all 21 roadmaps reviewed in this process. 


\section{State of Commercial New Construction}

\subsection{Industry Trends}

The U.S. construction industry appears to have stabilized after several years of decline, and some recent industry studies express optimism. Commercial new construction increased by $5 \%$ in 2012 , and is projected to increase by $12 \%$ in 2013 . The largest projected growth is in the retail sector, but similar growth is predicted across the commercial buildings sector. Tight lending practices and high vacancy rates remain major challenges to a strong recovery in commercial new construction. In addition, budget constraints for state and local governments have inhibited growth in the institutional building market (Engage360 2010). The construction rate for institutional buildings decreased by $13 \%$ in 2012, and no growth is projected in 2013 . The largest growth is expected in the southern and western regions of the United States. The combined investment in new construction for commercial and institutional buildings is projected to be $\$ 142$ billion in 2013. A summary of projected construction trends for several key building types CBI is shown in Figure 3-1.

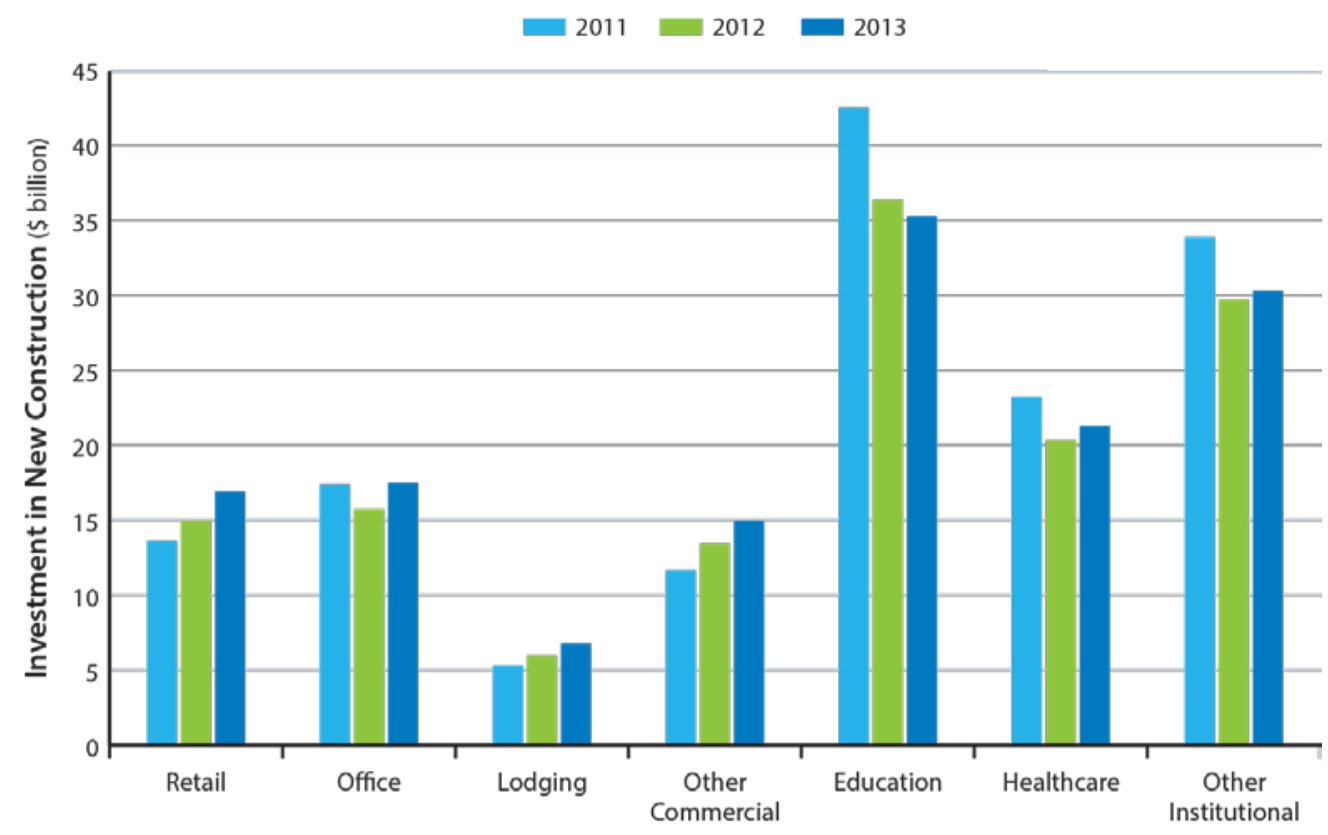

Figure 3-1 Recent and projected construction trends in the United States (\$ billion)

(McGraw Hill 2012a)

\subsection{Energy Use}

Historical and projected source energy use trends associated with existing and new (built after 2012) commercial buildings are shown in Figure 3-2 (DOE 2003, DOE 2012a). New construction is predicted to add approximately 0.40 quadrillion Btu (quads)/year to the total; the decommissioning and deconstruction of existing buildings, along with efficiency improvements through retrofits, reduce the projected total by about 0.28 quads/year. The cumulative source energy use for all commercial buildings constructed after 2012 is projected to be almost 7 quads/year by 2030. This will represent approximately $35 \%$ of all energy use associated with 
commercial buildings. Both the construction rate and the energy use intensity (EUI) of new commercial buildings are predicted to be relatively constant. These predictions indicate that EIA made very conservative assumptions about the market penetration of energy efficiency over the next 17 years. A scenario in which DOE's new construction research and deployment efforts successfully reduce the source energy use of new commercial buildings by $5 \% /$ year is indicated by the dashed line, ultimately leading to energy savings of 3.5 quads/year by 2030 .

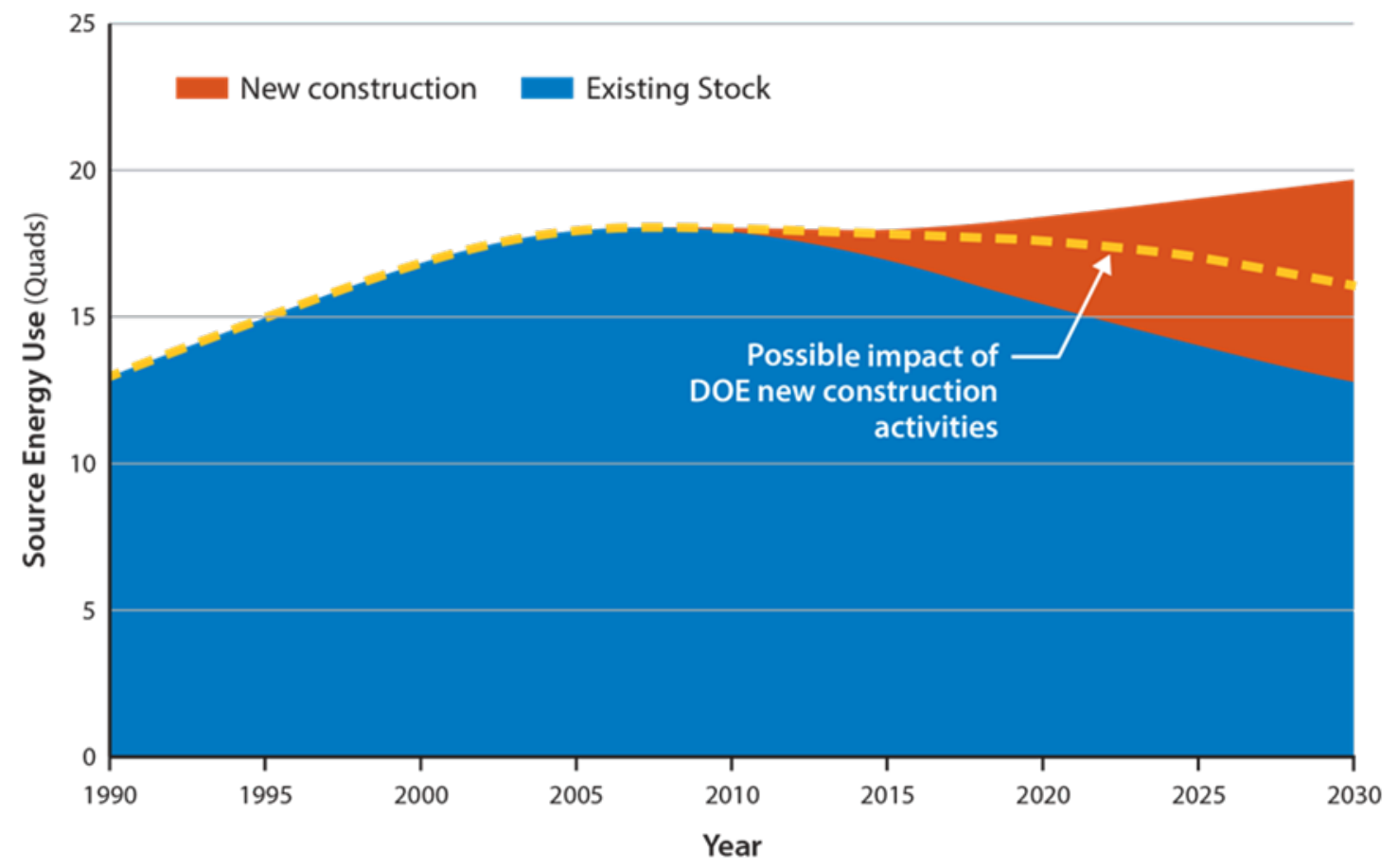

Figure 3-2 Energy use trends for commercial buildings

(DOE 2003, DOE 2012a)

The largest fraction of energy use in the commercial sector is consumed by office buildings, primarily because they are the most common building type (DOE 2003). Service, retail, and educational buildings also constitute a large fraction of energy use. Building types with the highest EUIs include laboratories, restaurants, and hospitals. Although these energy-intensive building types have high potential for energy savings, their use of specialized equipment presents unusual challenges for developing efficiency measures that can be manufactured and implemented at scale without sacrificing core functionality. The lowest EUIs are seen in warehouses and houses of worship (Griffith et al. 2007). A summary of the energy use characteristics of the 16 commercial building types analyzed in the 2003 Commercial Buildings Energy Consumption Survey (CBECS) is provided in Table 3-1.

\section{Source Energy}

Source energy reflects the total energy use associated with a building, including generation, distribution, and transmission losses. EIA applies a multiplier of approximately 3 to site electricity use to calculate source energy. No multipliers are used for other fuel types in EIA data. 
The energy end uses in commercial buildings are very diverse (see Figure 3-3). Lighting, heating, cooling, and ventilation are the largest individual loads, but numerous other equipment loads add up to a significant fraction of energy use and can be very challenging to address. Other equipment loads include service station equipment, automated teller machines, telecommunications equipment, medical equipment, pumps, emergency electric generators, and small-scale manufacturing. EIA's Annual Energy Outlook (DOE 2012a) does not predict a major shift in this end use breakdown by 2030, except for a small increase in the percentage of energy use associated with miscellaneous equipment loads. EIA also does not predict a large reduction in average EUI for new buildings ( $\sim 7 \%$ by 2035$)$, but the assumptions made by EIA can be conservative, and do not necessarily reflect implementation of a comprehensive set of programs targeting new construction. Clearly, a broad-based approach to efficiency improvements will be needed to significantly reduce energy use, including finding the right balance point between efficiency and renewable energy.

Table 3-1 Energy Use Characteristics of the 16 CBECS Building Sectors (DOE 2003)

\begin{tabular}{|c|c|c|c|}
\hline & $\begin{array}{l}\text { Source Energy } \\
\text { (trillion Btu) }\end{array}$ & $\begin{array}{c}\text { Source } \\
\text { Energy Intensity } \\
\left(\mathrm{kBtu} / \mathrm{ft}^{2}\right)\end{array}$ & $\begin{array}{l}\text { Floorspace } \\
\left(\text { million } \mathrm{ft}^{2}\right)\end{array}$ \\
\hline Office & 2,585 & 212 & 12,208 \\
\hline $\begin{array}{l}\text { Mercantile-Enclosed } \\
\text { and Strip Malls }\end{array}$ & 1,750 & 255 & 6,875 \\
\hline Education & 1,570 & 159 & 9,874 \\
\hline Lodging & 959 & 188 & 5,096 \\
\hline Warehouse and Storage & 879 & 87 & 10,078 \\
\hline Food Service & 857 & 518 & 1,654 \\
\hline Healthcare-Inpatient & 752 & 395 & 1,905 \\
\hline $\begin{array}{l}\text { Mercantile-Retail } \\
\text { (Other Than Mall) }\end{array}$ & 728 & 169 & 4,317 \\
\hline Food Sales & 668 & 532 & 1,255 \\
\hline Public Assembly & 637 & 162 & 3,939 \\
\hline Service & 590 & 146 & 4,050 \\
\hline Other & 488 & 281 & 1,738 \\
\hline Religious Worship & 288 & 77 & 3,754 \\
\hline Healthcare-Outpatient & 247 & 196 & 1,258 \\
\hline Public Order and Safety & 209 & 192 & 1,090 \\
\hline Vacant & 74 & 29 & 2,567 \\
\hline Total & 13,281 & 185 & 71,658 \\
\hline
\end{tabular}




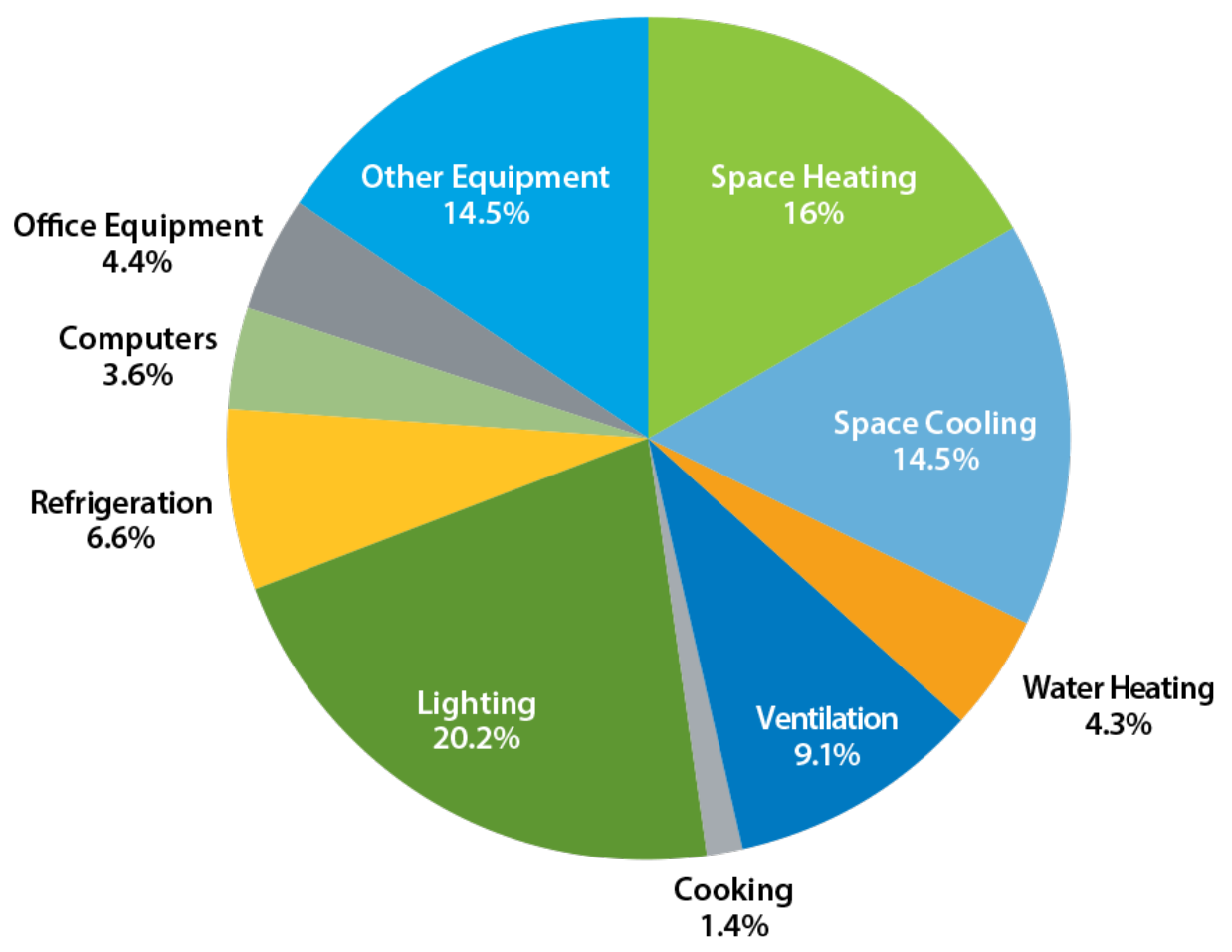

Figure 3-3 Source energy breakdown by end use in commercial buildings, 2012

(DOE 2012b)

\subsection{Trends in Energy Efficiency}

Some industry experts believe that the sluggish new construction market provides an opportunity to refocus the industry on greater energy efficiency and better project delivery methods as the market recovers (NBI 2012). McGraw Hill (2012b) indicates that more than half the construction firms interviewed will emphasize green buildings (defined as buildings designed to qualify under a recognized green building rating program) in the coming years, approximately twice the fraction currently doing so. According to the McGraw Hill study, this trend is largely driven by steadily increasing market demand for green buildings, in addition to public relations benefits and a desire to "do the right thing."

Challenges related to the diversity of building types, use patterns, ownership structures, leasing arrangements, and other considerations can be addressed by delivering a range of solutions tailored to the needs of a variety of stakeholders with very different motivations. Current energy efficiency initiatives have not had a major impact on the industry at large, but growing interest in green buildings, greater trends toward disclosure requirements and stretch codes at the local level, and increased public support for aggressive efficiency goals from key industry associations such as the American Institute of Architects (AIA) and ASHRAE provide reasons for optimism (Selkowitz et al. 2008).

NZE buildings remain a niche market, and only a handful of buildings in the United States have demonstrated achievement of that goal (NBI 2012). Several innovative owners and design firms are striving to meet the NZE target ahead of the rest of the industry, and many more have 
targeted high performance ( $>50 \%$ better than ASHRAE 90.1-2007 or better than ASHRAE Standard 189.1-2011), but challenges remain even for those early adopters. The industry will not pursue NZE buildings en masse until their customers demand it consistently and a sufficient foundation has been established that NZE can be cost effective and low risk (Heschong Mahone Group, Inc. 2012).

\subsection{Key Leverage Points}

Although DOE's new construction research and deployment activities may address a wide variety of stakeholders, it is important to begin by targeting a few key audiences that drive and influence transformation in the commercial buildings market. Stakeholders emphasized the importance of ongoing engagement with the following six audiences:

- Building owners

- Real estate developers

- Design professionals

- Corporate executives

- Building operators

- Financial institutions.

A number of key collaborators can be consulted and leveraged to reach these target audiences. Stakeholders mentioned the following collaborators most often:

- Building Owners and Managers Association (BOMA)

- Organizations focused on high performance buildings, such as New Buildings Institute (NBI), Alliance to Save Energy, and the American Council for an Energy-Efficient Economy

- Local governments

- ASHRAE, AIA, the U.S. Green Building Council (USGBC), and other professional groups

- Industry trade associations

- Real estate consortia

- Better Buildings Alliance (BBA)

- Regional energy collaboratives

- State governments/National Association of State Energy Offices (NASEO)

- Code officials/International Code Council (ICC)

- Utilities. 


\subsection{Use of Existing DOE Resources}

Stakeholders identified the DOE resources with which they are most familiar and use most often. This information represents a small sampling of industry perspectives, and was not collected in a scientific manner. Nevertheless, it provides some insight into the market penetration and usefulness of DOE products in support of energy efficient new commercial buildings. The following resources were the most commonly referenced by stakeholders:

- Advanced Energy Design Guides (AEDGs)

- Case studies

- Modeling tools (EnergyPlus, DOE-2.1E, OpenStudio, Simergy, COMFEN fenestration design tool, suite of windows analysis software)

- High Performance Buildings Database

- BBA resources (such as fact sheets and technology specifications that help ensure quality in the procurement process).

A variety of additional resources are available from non-DOE sources. Those resources were neither compiled nor analyzed as part of this project. 


\section{Gap Analysis}

A thorough gap analysis was conducted to identify research and deployment priorities. In response to these priorities, DOE may consider launching new programs or expanding existing programs to address underserved needs in the industry. A two-pronged approach was applied:

1. Compare the current DOE portfolio to barriers identified in existing roadmaps.

2. Solicit direct input from stakeholders about important gaps that could be addressed.

The first approach used a bottom-up methodology. Barriers to high performance commercial buildings were extracted from the 21 existing roadmaps discussed in Section 2.3, and crosschecked against the publicly stated objectives of DOE programs that are relevant to commercial new construction. Any barrier not identified as a primary focus of any current program was categorized as a potential gap in the DOE portfolio.

The second approach was top down in nature. More than 50 stakeholders representing diverse sectors of the commercial new construction industry were asked to identify barriers DOE could focus on, in both the near term and long term. At times, these "gaps" represented potential new areas of focus for DOE. Other times, the stakeholders recommended a re-emphasis or simply a continuation of existing DOE programs.

Results of the gap analysis were aggregated into nine candidate focus areas, which were then refined and prioritized during the stakeholder roundtable meeting held on February 21, 2013 in Golden, Colorado, and two subsequent webinars conducted with building owners and commercial real estate developers. Ultimately, the process identified five focus areas that became the foundation of the proposed strategies. The following sections describe the gap analysis results in more detail.

\subsection{Results of Approach \#1: Analysis of Barriers and Existing DOE Programs}

Figure 4-1 illustrates the basic bottom-up approach to gap analysis. After DOE's portfolio was characterized (Step 1), and technical and market barriers were identified (Step 2), a series of matrices was developed to highlight the barriers that DOE programs, tools, and resources may not currently address as a primary focus (Step 3).

Key barriers were extracted from 12 of the roadmaps described in Section 2.3. Similar barriers were aggregated or rephrased to facilitate categorization and analysis. In total, 69 unique barriers were identified and organized into 15 general categories. Initial filtering was performed to eliminate barriers outside of DOE's core capabilities (e.g., developing state tax incentives and improving utility rate schedules), barriers outside the scope of this study (e.g. building codes and standards), and barriers that were mentioned in only one roadmap. This filtering was not intended to minimize the importance of such barriers, but to focus initially on areas where DOE could have the greatest impact. The remaining 30 high priority barriers were included in the gap analysis. The full list of barriers and the results of the filtering process are provided in Appendix B. The gap analysis revealed that most DOE programs already focus on one or more key barriers identified in the literature. These barriers remain important ongoing priorities for DOE and play key roles in the proposed strategies. Barriers in each category that were not identified as a 
primary focus of any current programs were categorized as apparent "gaps" in the DOE portfolio. The resulting eight gaps were then ranked based on the number of roadmaps that identified the underlying barrier (see Table 4-1).

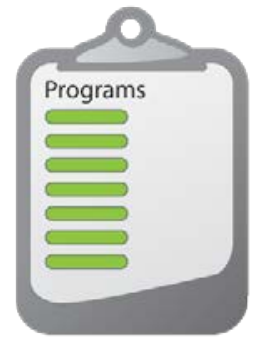

1

Identify DOE

Programs

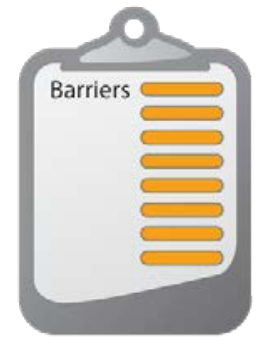

2

Identify Technical and Market Barriers

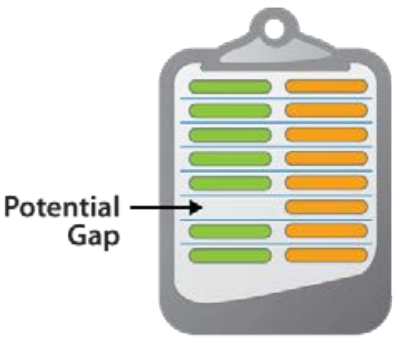

3

Between Programs

and Barriers

Figure 4-1 Gap analysis approach \#1

\section{Table 4-1 Research and Deployment Gaps Identified Using Approach \#1}

\begin{tabular}{|c|l|c|}
\hline Gap \# & \multicolumn{1}{|c|}{ Gap Description } & $\begin{array}{c}\text { Number of } \\
\text { Citations }\end{array}$ \\
\hline 1 & $\begin{array}{l}\text { Owners and lenders focus on the cost of construction or short-term returns } \\
\text { on investment but ignore long-term operating cost savings from improved } \\
\text { building performance }\end{array}$ & 7 \\
\hline 2 & Capital budgets and operating budgets are set and managed independently & 7 \\
\hline 3 & $\begin{array}{l}\text { Building operator education and certification are needed for high } \\
\text { performance and NZE buildings }\end{array}$ & 7 \\
\hline 4 & $\begin{array}{l}\text { The industry lacks data about the cost effectiveness of high performance } \\
\text { buildings that use leapfrog technologies and design approaches }\end{array}$ & 6 \\
\hline 5 & \begin{tabular}{l} 
Better disclosure requirements for energy performance data are needed \\
\hline 6
\end{tabular} & $\begin{array}{l}\text { An overabundance of metrics is being used in too many ways to allow for easy } \\
\text { benchmarking and comparisons }\end{array}$ \\
\hline 7 & $\begin{array}{l}\text { Ingrained practices in the financial and real estate sectors fail to sufficiently } \\
\text { recognize the increase in building value associated with energy efficiency } \\
\text { improvements }\end{array}$ & 3 \\
\hline 8 & $\begin{array}{l}\text { Energy cost impacts of specific behaviors and operational practices are not } \\
\text { well understood }\end{array}$ & 3 \\
\hline
\end{tabular}

\subsection{Results of Approach \#2: Industry Stakeholder Conversations}

For the second approach to gap analysis, more than 50 key stakeholders from 32 organizations were engaged in candid conversations with NREL and LBNL about a variety of topics, including areas where DOE could focus its research funding to have the greatest impact in the new construction market. LBNL focused on partners in the architecture, engineering, construction, 
and owner/operator (AECO) community. NREL gathered similar information from utilities, state governments, industry associations, regional energy associations, building owners, and real estate developers. The following diverse organizations participated in the direct stakeholder conversations:

- Architectural firms
- CO Architects
○ DLR Group
○ FXFowle
○ Gensler
○ HOK
○ Payette
○ SERA Architects
○ Skidmore, Owings \& Merrill LLP
- The ABO Group, Inc.

- Engineering firms
○ Affiliated Engineers Inc.
$\circ$ Arup
○ Atelier Ten
- Buro Happold
- Integral Group
○ JB\&B
○ Vanderweil Engineers

- Commercial building owners and developers
○ Gundersen Lutheran Health System
○ Hines
- MD Anderson Cancer Center
○ New York Presbyterian Hospital
○ Target

- Utilities

○ Sacramento Municipal Utility District

- Construction companies
○ Skanska
○ Webcor Builders 
- Non-profits

- Northwest Energy Efficiency Alliance

○ Portland Energy Conservation, Inc.

- Universities

- University of Washington Integrated Design Lab

- Manufacturers

- Trane Ingersoll Rand

- Government agencies

- U.S. General Services Administration (GSA)

- Other industry experts

- Building Design + Construction

- E Source.

The interviews led to interesting discussions, observations, and gap identifications pertaining to different stages in the design and construction process. Participants expressed a range of views, but many consistent themes emerged, resulting in the set of potential gaps listed in Table 4-2. 


\section{Table 4-2 Perceived Research and Deployment Gaps Identified through Stakeholder}

Conversations (Approach \#2)

\begin{tabular}{|c|c|}
\hline Gap \# & Perceived Gap Identified by Stakeholders \\
\hline 1 & $\begin{array}{l}\text { Cost-effectiveness could be proven across a broader range of buildings (e.g. through } \\
\text { stronger case studies) before the market will embrace a target of NZE. }\end{array}$ \\
\hline 2 & $\begin{array}{l}\text { In addition to an aspirational NZE goal, realistic interim and alternative goals would } \\
\text { help encourage broad participation. }\end{array}$ \\
\hline 3 & $\begin{array}{l}\text { Interactive resources that are more context applicable may be needed to make } \\
\text { comprehensive DOE resources like Advanced Energy Design Guides (AEDGs) more } \\
\text { accessible and user friendly. }\end{array}$ \\
\hline 4 & $\begin{array}{l}\text { Better purchase, installation, and nonenergy cost data could help inform design } \\
\text { decision-making. }\end{array}$ \\
\hline 5 & $\begin{array}{l}\text { Design guidance and target EUls could be tailored more to specific climates (e.g., } \\
\text { California, Texas) and building types (e.g., small buildings). }\end{array}$ \\
\hline 6 & $\begin{array}{l}\text { Better modeling tools, ideally with Building Information Modeling integration, could } \\
\text { help support design and operations. }\end{array}$ \\
\hline 7 & $\begin{array}{l}\text { User awareness of and access to DOE information and data resources could } \\
\text { be improved. }\end{array}$ \\
\hline 8 & $\begin{array}{l}\text { Greater attention to ongoing maintenance and enhancement of DOE information } \\
\text { and data resources could be helpful. }\end{array}$ \\
\hline 9 & $\begin{array}{l}\text { Clear benchmark data for energy performance could be established for different } \\
\text { building types. }\end{array}$ \\
\hline 10 & $\begin{array}{l}\text { Enhanced energy efficiency education, training, and awareness initiatives would be } \\
\text { beneficial. }\end{array}$ \\
\hline 11 & $\begin{array}{l}\text { Integrated, user-friendly databases could be developed or expanded to make a } \\
\text { variety of data and tools useful to a wider audience. }\end{array}$ \\
\hline 12 & $\begin{array}{l}\text { New approaches to "value engineering" and other project delivery challenges could } \\
\text { be developed. }\end{array}$ \\
\hline 13 & $\begin{array}{l}\text { The process for deploying new technologies into systems, then integrating across } \\
\text { those systems to whole buildings could be streamlined. }\end{array}$ \\
\hline 14 & $\begin{array}{l}\text { Effective commissioning and operational strategies would be valuable, particularly } \\
\text { when more complex integrated systems are specified. }\end{array}$ \\
\hline 15 & $\begin{array}{l}\text { Confidence in system-level cost estimating approaches is lacking, including } \\
\text { technology and installation, and resources to enable integrative design. }\end{array}$ \\
\hline 16 & Effective approaches could be developed for implementing analytics on projects. \\
\hline 17 & $\begin{array}{l}\text { Better approaches and data would allow integration of nonenergy benefits into } \\
\text { design decisions. }\end{array}$ \\
\hline 18 & Greater access to measured performance data for key projects would be valuable. \\
\hline
\end{tabular}

\subsection{Stakeholder Roundtable and Webinars}

Additional group discussion was required to prioritize and refine the preliminary set of gaps based on their importance to the commercial market, their alignment with DOE's mission, and the extent to which they have already been addressed by resources from past DOE programs or from outside DOE. These steps, in addition to gathering feedback and overall insight, were the focus of the stakeholder roundtable meeting held at NREL in Golden, Colorado, on February 21, 2013. 
A diverse group of 23 commercial building stakeholders participated in the roundtable, including representatives from:

- Architectural firms
○ DLR Group
○ HOK
○ SERA Architects
○ Skidmore, Owings \& Merrill LLP

- Engineering firms
○ Arup
- Buro Happold
○ Integral Group
- RNL Design
○ Vanderweil Engineers

- Building owners and developers

○ Target

- Utilities
- Pacific Gas \& Electric
- Sacramento Municipal Utility District
○ Xcel Energy

- Construction companies

○ Webcor Builders

- Non-profits

- Northwest Energy Efficiency Alliance

○ PECI

○ U.S. Green Building Council

- Universities

- University of Washington College of Built Environments

- Manufacturers

○ Trane Commercial Systems

- Government agencies

○ GSA

- National Aeronautics and Space Administration 
- Colorado Energy Office

- City of Westminster.

NREL also hosted two webinars in late February 2013 with commercial building owners, tenants, and real estate developers who, because of scheduling conflicts, were not represented at the roundtable. As these are some of the most important audiences in the new construction industry, it was vital to include their input before finalizing the list of high priority focus areas. Seven organizations were represented from the following categories:

- Commercial building owners and owner's representatives

○ Fitzmartin Consulting

- MD Anderson Cancer Center

- New York Presbyterian Hospital

○ Target

- Tenants

○ Whole Foods

- Real estate developers

○ Hines

○ Prologis.

NREL and LBNL asked participants in the roundtable meeting and the webinars to identify several high priority focus areas where they felt DOE could most effectively accelerate progress toward NZE buildings in the near and long terms. Participants were also asked to identify potential partner organizations as well as possible near- and long-term strategies for each focus area. The results of the roundtable meeting and the two webinars were important considerations for NREL and LBNL as the activities proposed in Section 5.0 were developed.

After considering all stakeholder input, five key focus areas were identified as the framework for the proposed research and deployment efforts described in Section 5:

1. Energy benchmark data. System- and whole building-level energy benchmark data, organized by building type and climate, which can be used to set performance targets for new buildings

2. Enhanced modeling tools. Improved modeling tools to support financial decisionmaking, whole-building design, analysis of new technologies, model calibration, and identification of operational and behavioral influences on energy use throughout the building life cycle

3. Better cost data. Objective, vetted average component- and system-level cost data for analysis of return on investment

4. Commissioning and operational strategies. Effective commissioning and operational methods, technologies, and tools, demonstrated through case studies 
5. Integrated resources. Integrated resources that present new construction case studies, best practice guides, datasets, and tools in a more accessible, adaptable, and user-friendly format. 


\section{Recommendations}

This section describes recommendations for DOE's research and deployment programs related to new commercial buildings. The proposed activities are designed to have the greatest long-term impact on the market. All recommendations, including goals, definitions, priority research areas, and key collaborators reflect the opinions of the authors based on inputs from stakeholders, a review of the literature, and the authors' own experience and expertise in commercial building energy efficiency research and market deployment. Before possible adoption by DOE, recommendations must be further reviewed and aligned with federal priorities, policy objectives, funding priorities, and roles and responsibilities within $\mathrm{CBI}, \mathrm{BTO}$, and other DOE programs.

\subsection{Program Goals}

The recommended long-term energy efficiency goal for new commercial buildings is to achieve significant market penetration of cost-effective NZE buildings in all building sectors and climates by 2030 . This goal would be aligned with EISA requirements, which call for the nation to realize economically viable NZE buildings in new commercial construction by 2030, in half the commercial building stock by 2040, and for all commercial buildings by 2050 . The authors recognize that economic viability may not require adherence to strict costeffectiveness metrics based on energy savings, because energy efficiency can offer many non-energy benefits that may contribute to the building owner's mission, such as health, safety, comfort, and good will. However, because these benefits are very difficult to quantify monetarily, they

New Construction Long-Term Goal

Significant market penetration of cost-effective NZE buildings in all commercial building sectors and climates by 2030 . are not explicitly included in the determination of economic viability.

Even though the recommended goal is based on NZE, the proposed research and deployment solutions focus on NZER, which is the energy efficiency component of NZE, and on high performance buildings spanning the range from code minimum to NZER. Definitions of NZE and NZER are discussed further in Section 5.2.

Griffith et al. (2007) conducted an NZE technical potential study, which indicated that many building types (non-refrigerated warehouses, schools, standalone retail stores, and houses of worship, which comprise nearly $60 \%$ of commercial floor area) can achieve NZE if 50\% site energy savings are achieved (compared with ASHRAE Standard 90.1-2004). The study indicated that an additional set of building types (office, public assembly, service, public order and safety, outpatient healthcare, and refrigerated warehouse, which comprise more than $25 \%$ of the remaining commercial floor area, summing to nearly $85 \%$ of the floor area in total) could achieve NZE if $67 \%$ site energy savings are achieved. These efficiency levels are aggressive but achievable, as documented through modeling and case studies in the 50\% AEDGs (http://www1.eere.energy.gov/buildings/commercial/aedg.html).

Although the recommended long-term goal is NZE commercial buildings, intermediate goals could be necessary to have a broader impact in the near term (0-3 years), and to track progress toward the long-term goal. These intermediate goals may be different for each of the 16 generally recognized climate zones in the United States (see Figure 5-1), and additional analysis may be required to fully understand the challenges associated with achieving NZE buildings of 
each type in certain climate zones. Although the timeline for certain building types may call for a long-term approach, a few near-term, high profile demonstration projects for these building types could raise interest in the marketplace and drive the overall movement. An NBI study documents the characteristics of 60 examples of NZE and "NZE capable" buildings, primarily office and educational buildings, along with financial data and lessons learned (NBI 2012). Section 5.3 provides further discussion of proposed timelines for intermediate goals.

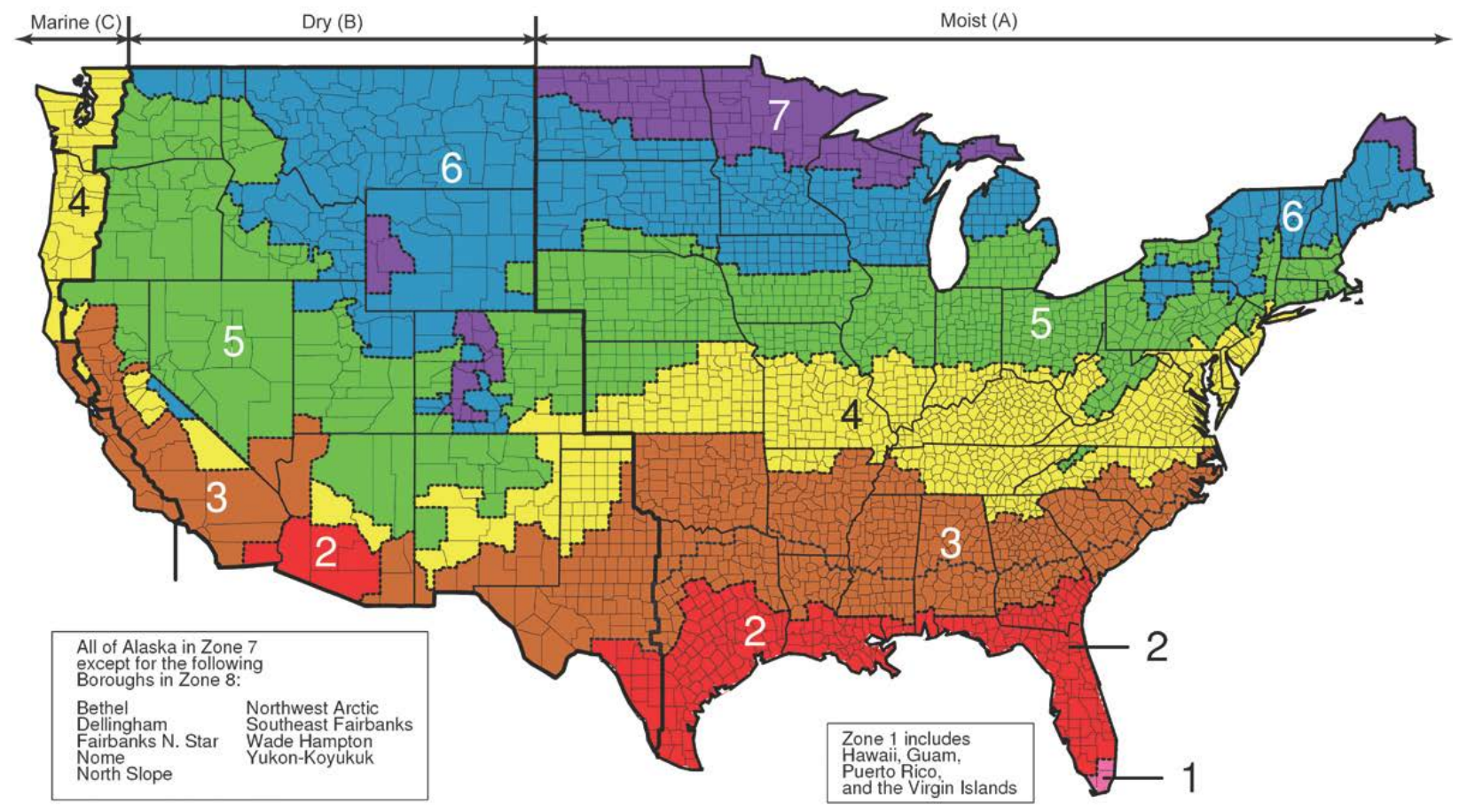

Figure 5-1 United States climate zones used in ASHRAE 90.1 (Briggs et al. 2003)

\subsection{Definitions}

There is considerable debate in the industry about the best definitions of NZE and NZER. Although this report does not aim to settle the debate, a clear definition of NZER was deemed necessary by the authors to allow quantitative EUI targets that could be used to track progress toward recommended program goals and demonstrate achievement of those goals. The following definitions were developed by the authors (NREL and LBNL) after considering all of the input from stakeholders, and are recommended for the purpose of setting and tracking goals for new commercial buildings:

- NZER: A building that includes all efficiency measures that are more cost effective than renewable energy

- NZE: A building that generates as much source energy using renewable energy sources as it consumes on an annual basis, and complies with one or more of the class definitions in Pless and Torcellini (2010) 
- Cost-effective NZE: A building meeting the definition of NZE with a life cycle cost less than a similar building constructed in accordance with the minimum requirements of ASHRAE 90.1-2010.

Different NZE definitions may be appropriate in certain circumstances, depending on the project goals and the values of the design team and building owner. As documented and discussed by Torcellini et al. (2006), four commonly used accounting methods are net-zero site energy, netzero source energy, net-zero energy costs, and net-zero energy emissions. Each definition uses the grid for net use accounting but has different applicable renewable energy sources.

- Net-zero site energy: A site NZE building produces at least as much renewable energy as it uses in a year, when accounted for at the site.

- Net-zero source energy: A source NZE building produces (or purchases) at least as much renewable energy as it uses in a year, when accounted for at the source. Source energy refers to the primary energy used to extract, process, generate, and deliver the energy to the site. To calculate a building's total source energy, imported and exported energy is multiplied by the appropriate site-to-source conversion multipliers based on the utility's source energy type. This definition is recommended as the basis for calculating EUIs consistent with NZER performance.

- Net-zero energy costs: In a cost NZE building, the amount of money the utility pays the building owner for the renewable energy the building exports to the grid is at least equal to the amount the owner pays the utility for the energy services and energy used over the year.

- Net-zero emissions: A net-zero emissions building produces (or purchases) enough emissions-free renewable energy annually to offset emissions (commonly carbon, nitrogen oxides, and sulfur oxides) from all energy used in the building. To calculate a building's total emissions, imported and exported energy is multiplied by the appropriate emission multipliers based on the utility's emissions and on-site generation emissions (if there are any).

Although NZE is fairly straightforward to understand and demonstrate for individual projects, NZER can be quite a difficult target to verify. Therefore, it could be valuable to establish a series of specific EUI targets that can be used by industry to set goals and verify performance. Each EUI target would correspond to the NZER point on the optimal life cycle cost curve for a typical example of the relevant building type (see Figure 5-3). The life cycle cost curve defines the most cost-effective efficiency package at each

Use of Source Energy Metrics

Energy use is quantified throughout this report in terms of source energy, because it reflects the total energy use associated with a building, including generation, distribution, and transmission losses. As solution paths are explored in detail at the individual project level, it is important that the resulting market-facing products use metrics for energy use that reflect the needs and workflows of the intended audiences. level of energy savings. This curve may vary significantly depending on the building type and climate region, and can also be influenced by operating hours, HVAC system type, level of occupancy, and other variables. The EUI targets would include all energy uses in the building, 
including miscellaneous electric loads. EUI targets may change over time, and changes in technology, measure costs, and energy prices may be revisited as necessary to determine if lower EUI targets are justified. Definitions recommended by the authors for the terminology used in Figure 5-2 are provided below:

- Total life cycle cost (TLCC). The discounted total cost associated with utility bills, energy efficiency measures, operations and maintenance (O\&M) of energy systems, and other energy-related costs over a selected project analysis period (usually 20-30 years).

- Inputs. Analysis period, discount rate, measure costs, measure lifetimes

- Incorporates. Capital costs, O\&M costs, energy costs, replacement and salvage costs, tax implications, impact on resale value.

- Optimal life cycle cost curve. A series of points, approximated by a curve, representing packages that achieve a specific level of energy savings at the lowest TLCC

- Baseline. A fixed building design that complies with the minimum requirements of ASHRAE 90.1-2010

- Cost minimum. An efficiency package that minimizes TLCC; maximum return on investment

- Cost neutral. An efficiency package with the same TLCC as the baseline; maximum efficiency level that can be achieved cost effectively

- NZER. An efficiency package that includes all efficiency measures that are more cost effective than renewable energy

- NZE. Adding renewable energy generation to an NZER efficiency package as needed to achieve net-zero source energy use on an annual basis.

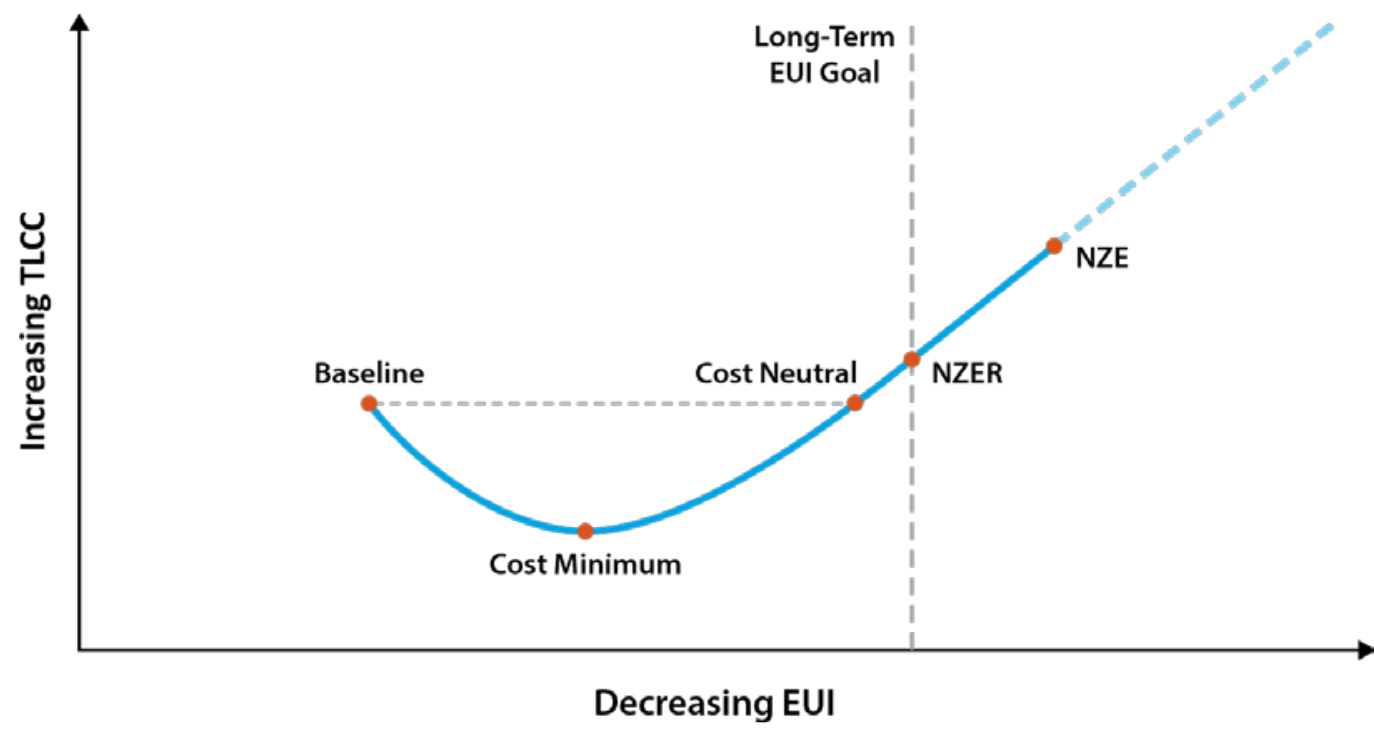

Figure 5-2 NZE and NZER in context of optimal life cycle cost curve 
Based on these definitions, cost-effective NZE would be achieved for a particular building when the EUI associated with NZER is met and the TLCC of the NZE package falls below the cost neutral line. Improvements in energy efficiency technology and reductions in the cost of energy efficiency measures (and renewable energy generation) will gradually shift the optimal curve downward, ultimately leading to NZE buildings with lower life cycle costs than similar baseline buildings that comply with the minimum requirements of ASHRAE Standard 90.1-2010 (see Figure 5-3). Because cost reductions and technology improvements may also affect the TLCC of the baseline, all points in Figure 5-3 are interpreted relative to a baseline with fixed EUI but variable TLCC.

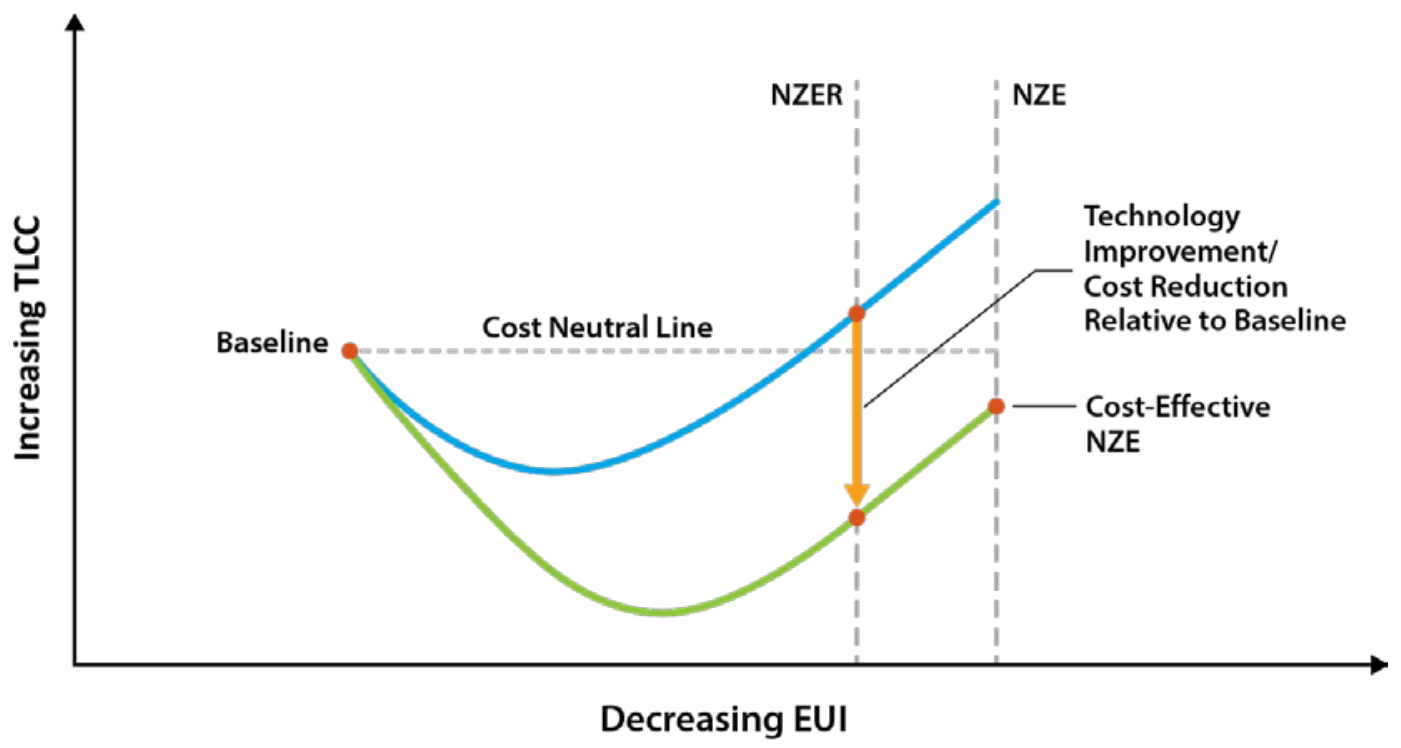

Figure 5-3 Achieving cost-effective NZE buildings

The proposed NZER definition would be compatible with the NZE framework previously recommended by NREL, including the NZE building definition system developed by Torcellini et al. (2006) and the classification grading system proposed by Pless et al. (2011). It would also provide complete flexibility with respect to renewable generation technology selection. NZER defines a state of energy efficiency; as such, it is likely to be compatible with all definitions and classifications of NZE performance.

While the proposed definition addresses the concept of NZER at the single building scale, it could apply equally well to projects of any scale. At the community or microgrid scale, NZER efficiency packages may contain measures that are not applicable to the single building scale, such as district-level heating, cooling, and energy recovery strategies. Additionally, communityscale projects may be able to take advantage of economies of scale associated with the implementation of renewable energy generation. Regardless of the types of measures that comprise the NZER efficiency package or the price of renewable energy generation that defines cost effectiveness, the spirit of the NZER definitions would remain the same: reduce project EUI to the point that renewable energy generation is the most cost-effective strategy remaining, whether it be at the building, community, or microgrid scale. 


\subsection{Overall Strategy}

This report emphasizes solutions that are likely to accelerate the decision to act, the learning curve, and the adoption curve for the energy efficiency component of NZE buildings. A broadbased approach is emphasized, balancing innovation, technology, policy, market, strategic deployment, and economic considerations. Highly motivated and knowledgeable owners will likely be the early adopters, influencing the pace of awareness and acceptance; other owners may require additional information or incentives before deciding to act. Lessons learned from the successes and failures of early adopters can be communicated to reach hesitant or risk-averse audiences.

The proposed strategy for achieving the long-term goal of cost-effective NZER buildings by 2030 focuses on three stages of the market transformation process: (1) development, (2) demonstration, and (3) deployment. A logical progression through each stage for each building type and climate combination may steadily increase the scale of NZER from single buildings, to portfolios and neighborhoods, and eventually to broad market penetration. Completion of each stage can be validated using a stage-gate process with specific metrics and go/no-go decision points. Before advancing to the next stage, a sufficient number of projects may be required to demonstrate that key principles and best practices are well understood and ready for broader application. There are likely to be some areas of overlap between stages, because the diversity of buildings in each sector may present unique opportunities to initiate early deployment for certain niche markets, while other situations are likely to present residual technical challenges where further research or technology demonstration is required. The stage-gate process recommended for a possible large-scale integrated new construction initiative is summarized in Figure 5-4.

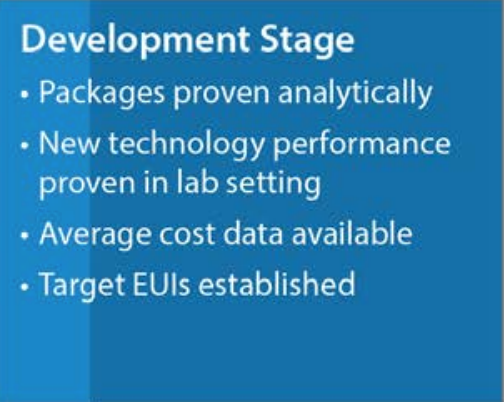

Demonstration Stage

- Energy savings proven in real buildings

- Cost-effectiveness proven in real buildings

- Systems interactions of new technologies understood

- Target EUls validated
Deployment Stage - Design resources available - O\&M best practices defined - Target EUIs accepted by industry

Figure 5-4 Recommended new construction stage-gate criteria 
The stage-gate process could be conducted for each of the 16 commercial building types defined in CBECS. Certain building types, such as warehouses, may be ready for deployment immediately; others may require several years of effort to develop lower cost measures and improved technical approaches before NZER can be achieved on a large scale. Figure 5-5 illustrates possible timelines for three building types, each beginning at a different stage on the path to deployment. Detailed timelines for all building types could be an early priority, and is likely to be a prerequisite to establishing realistic intermediate goals. Finer resolution may be added in recognition of unique challenges in certain climate regions and for smaller buildings. Conversely, there may be enough commonalities and synergies between certain building types that they can be grouped into fewer parallel stage-gate paths. The following preliminary breakdown of key building types in each category provides a starting point for discussion:

- Building Type A. Warehouse, Education, Retail

- Building Type B. Office/Professional, Food Sales, Assembly, Lodging

- Building Type C. Food Service, Healthcare

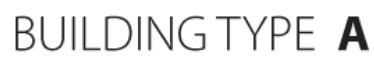

DEPLOYMENT

BUILDING TYPE B

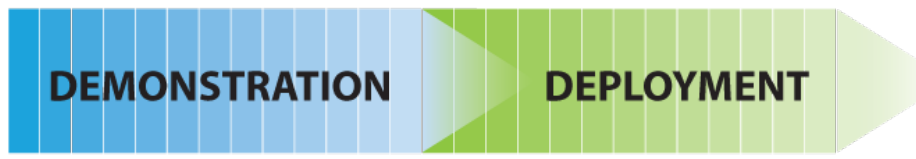

BUILDING TYPE C

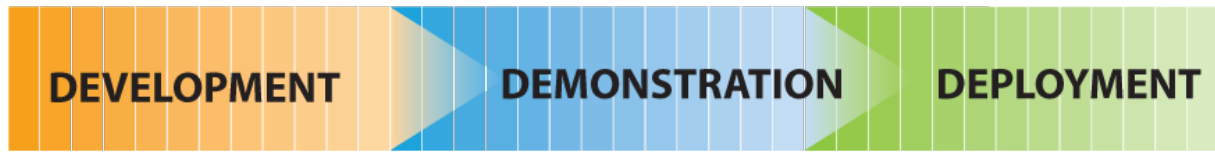

NEARTERM

LONG TERM

Figure 5-5 Example stage-gate timelines for different commercial building types

A proposed classification system was developed for organizing recommended solutions in each focus area:

- Inspirational. Stimulate positive attitudes and instill greater confidence in the achievability of NZE buildings. 
- Motivational. Catalyze action by proving the practicality and cost effectiveness of NZE, and identify opportunities for better financial returns through incentives, labeling, or more accurate valuation methods.

- Procedural. Guide members of the project delivery team through all phases of the process, ensuring through proper planning, communication, and integration that goals are achieved.

- Practical. Provide data, tools, and educational resources that support detailed analysis and decision-making on the front lines of design, construction, and operations.

Example products and resources in each class are presented in Figure 5-6.

\begin{tabular}{ll}
\hline Inspirational & $\begin{array}{l}\cdot \text { LEADERSHIP } \\
\cdot \text { GOALS } \\
\cdot \text { SUCCESS STORIES }\end{array}$ \\
\hline Motivational & $\begin{array}{l}\cdot \text { INCENTIVES } \\
\cdot \text { TECH DEMOS } \\
\cdot \text { RECOGNITION/AWARDS }\end{array}$ \\
\hline Procedural & $\begin{array}{l}\cdot \text { GUIDANCE } \\
\cdot \text { INTEGRATED RESOURCES } \\
\cdot \text { TEMPLATES }\end{array}$ \\
\hline Practical & $\cdot$ TRAINING \\
& $\cdot$ MODELING TOOLS \\
& $\cdot$ OBJECTIVE DATA \\
\hline
\end{tabular}

Figure 5-6 Proposed classification system for new construction solutions

Certain classes are likely to be more impactful than others, depending on the construction stage. For example, inspirational measures can stimulate the initial decision to act, but are not likely to affect the ability of facility managers to effectively operate NZER buildings. Similarly, practical solutions, such as better cost data, may be very helpful to architects and engineers, but are generally not needed for green building certification programs. The projected impact of each solution class is summarized in Figure 5-7. 


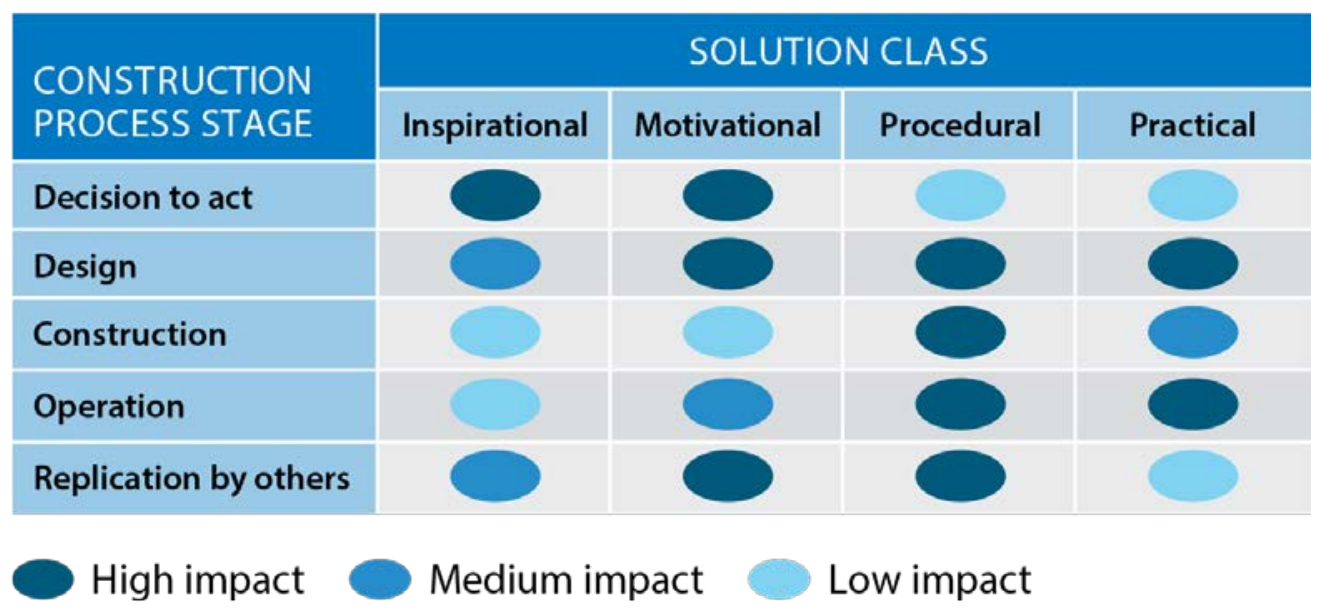

Figure 5-7 Projected impacts of solution classes at various construction stages

In accordance with this general strategy, the following five sections present critical needs, key collaborators, possible solutions, and approximate timelines for each of the key focus areas presented at the end Section 4.

1. Energy benchmark data.

2. Enhanced modeling tools.

3. Better cost data.

\section{Commissioning and operational strategies.}

\section{Integrated resources.}

\subsection{Focus Area \#1: Energy Benchmark Data}

End use- and whole building-level energy benchmark data are necessary for setting realistic yet aggressive performance targets for new buildings of various types in different climates. Energy benchmarks also serve as standard points for goal setting by market actors such as owners, designers, and operators. Benchmark cost information is also valuable for many purposes in the early design phase; this topic is addressed in Section 5.7.

\subsubsection{Critical Needs}

EUI targets for higher performing new buildings, including NZER, have not been established in a standardized manner. A large-scale effort may be necessary to categorize and quantify the energy use of best-in-class new commercial buildings and their major end uses to establish aggressive long-term energy use targets that define a path to NZER. These energy benchmark data can be organized by building type and climate, two key drivers of energy use in new commercial buildings. Although a significant amount of data are available from CBECS, Portfolio Manager, the Buildings Performance Database, and other sources, these datasets are either weighted toward older buildings or include a large amount of voluntary data, which may have self-selection bias. ENERGY STAR recognizes new buildings that perform in the top 25\% of the existing building stock based on CBECS data, and Target Finder is a valuable tool for 
identifying the EUI corresponding to the ENERGY STAR performance level of a new building or to a certain percentile of the CBECS dataset. The DOE Buildings Performance Database is a new resource with a rapidly growing dataset with extensive filtering capabilities, but does not yet have sufficient data for establishing robust benchmark values across a broad range of building types and climates.

Standard adjustment factors may be needed to account for building size, market, occupant activities and density, hours of operation, and other drivers such as year of construction (for possible application of the benchmarks to existing buildings). The U.S. Environmental Protection Agency (EPA) has already developed adjustment factors for Portfolio Manager, but some effort may be required to adapt them to new construction and to derive system-level adjustment factors. These adjustments can help to account for the variability from one building to the next, allowing higher statistical significance with smaller sample sizes. New metrics may be needed to normalize energy use in ways that better align with design and construction workflows.

Figure 5-8 links each need with its core audience and identifies the design and construction stages that could benefit most if it is successfully addressed.

\begin{tabular}{|c|c|c|c|c|c|}
\hline & $\begin{array}{c}\text { Decision } \\
\text { To Act }\end{array}$ & Design & Construction & Operation & Replication \\
\hline $\begin{array}{l}\text { Rating/Labeling System } \\
\text { Audience: Owners, Deployment } \\
\text { Partners }\end{array}$ & & & & & \\
\hline $\begin{array}{l}\text { Whole-Building Energy Use } \\
\text { Targets for High-Performance } \\
\text { Buildings } \\
\text { Audience: Owners, Deployment } \\
\text { Partners, States and Municipalities }\end{array}$ & & & & & \\
\hline $\begin{array}{l}\text { Energy Use Targets for Key } \\
\text { Subsystems } \\
\text { Audience: Designers, Operators }\end{array}$ & & & & & \\
\hline $\begin{array}{l}\text { Standardized, Meaningful } \\
\text { Metrics } \\
\text { Audience:Designers, Operators }\end{array}$ & & & & & \\
\hline $\begin{array}{l}\text { Best Practices for Measuring } \\
\text { Performance Data } \\
\text { Audience: Operators, States and } \\
\text { Municipalities, Utilities }\end{array}$ & & & & & \\
\hline $\begin{array}{l}\text { Adjustment Factors Based on } \\
\text { Building Characteristics and } \\
\text { Usage Patterns } \\
\text { Audience: Owners, Designers }\end{array}$ & & & & & \\
\hline
\end{tabular}

Figure 5-8 Linking critical energy benchmarking needs to audience and impact 


\subsubsection{Strategic Approach}

Energy use benchmarks for new commercial buildings could be developed across four dimensions (see Figure 5-9). Benchmarks ranging from code minimum to best-in-class performance can provide practical reference points for setting a wide range of energy efficiency targets for new buildings. Each building sector may need to be addressed separately because of large inherent disparities in energy use related to equipment loads, operating hours, occupancy levels, and building size. Benchmarks will be most valuable to decision makers when they are expressed in terms of EUI, broken down by end use. Year of construction may be another important variable to track for the purpose of analyzing trends in the performance of new buildings over time, and the persistence of energy performance as new buildings begin to age.

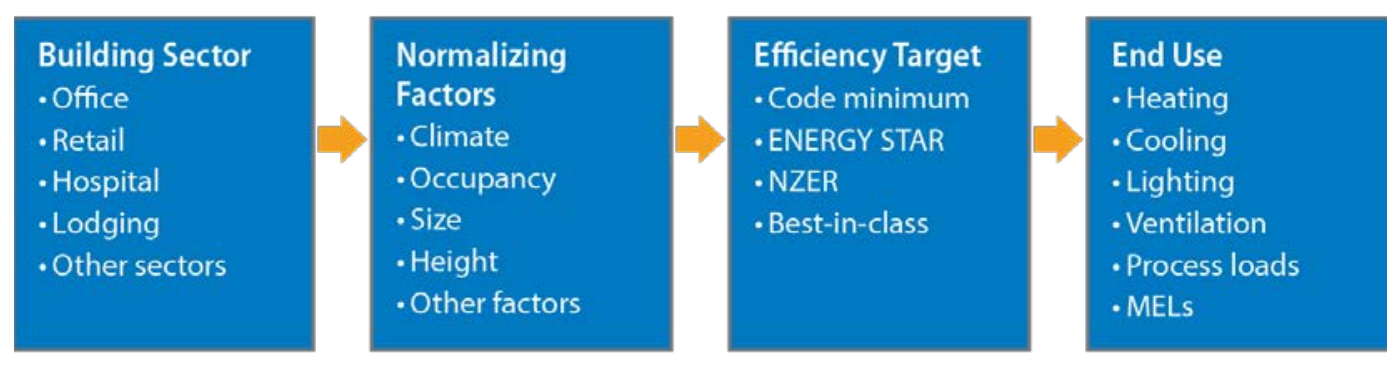

Figure 5-9 Dimensions of energy benchmark data needed for effective target setting

In the near term, detailed benchmark data may be calculated through numerous energy simulations, incorporating different sets of high performance strategies, validated using performance data for newer buildings from CBECS, the California Commercial End-Use Survey, the Building Performance Database, and other voluntary datasets. The emphasis would be on new construction, but benchmarks for older buildings would be useful for analyzing trends. Benchmarks could be established for whole buildings and major end uses. The DOE national laboratories can leverage possible enhanced modeling tool solutions discussed in Section 5.5, along with supercomputing capabilities and expertise in high performance building design, to complete this activity in an objective, comprehensive manner.

Passivhaus standards can be a useful reference point for certain end uses, including heating and ventilation. Although these standards are most often applied to residential buildings, their application to commercial buildings has expanded in recent years.

In the long term, benchmarks can be solidified using actual building data reported through voluntary and mandatory collection methods, including utility bill aggregation and energy use disclosure laws. Inexpensive $\mathrm{M} \& \mathrm{~V}$ protocols for collecting system-level data can be developed, including better methods for monitoring natural gas use for boilers, furnaces, water heaters, and cooking equipment. Improved methods for automated weather normalization could be developed so data from different time periods can be aggregated more efficiently.

There are many synergies, and some important differences, between benchmarking approaches for existing buildings and new buildings. Tools such as Portfolio Manager and Target Finder are valuable for identifying poorly performing buildings that are good candidates for retrofits, and 
helping building owners set energy performance targets for those buildings based on a large set of existing buildings with similar characteristics. These tools are less useful for discerning challenging design targets for high performance new buildings. Energy data for recently constructed buildings and older buildings that have been retrofitted for high performance would be helpful for developing new construction benchmarks, but such data are limited and a special effort would be required to collect more detailed data for new buildings through enhanced M\&V procedures and data disclosure requirements. Portfolio Manager and Target Finder will likely continue to be the vehicles that building owners use to set targets, but the power of those tools can be enhanced by expanding the datasets for high performance new buildings.

Existing metrics could be re-examined to determine their relevance and practicality for setting performance targets and evaluating achievement of those targets. The metrics most likely to be relevant to building owners include those listed in Table 5-1. Many other metrics reflect life cycle energy use or societal impacts, such as Time Dependent Valuation (PG\&E 2012), which is used by the State of California to address the impact of energy use on utilities. A few of these societal metrics are listed in Table 5-2. Key metrics can be standardized, and all organizations involved in data collection can be encouraged to report data in the same format so data from many sources can be aggregated. DOE's Building Energy Data Exchange Specification (BEDES) supports efforts to standardize energy data fields to improve the consistency of data collection, analysis, and reporting.

Table 5-1 Energy Performance Metrics Commonly Used by Building Owners

\begin{tabular}{|c|c|}
\hline Metric & Common Application \\
\hline Btu/ $\mathrm{ft}^{2}$ & Any building \\
\hline Energy cost/ $\mathrm{ft}^{2}$ & Any building \\
\hline Btu/employee & Office building \\
\hline Btu/unit of product & Assembly plant \\
\hline Btu/lb of product & Manufacturer \\
\hline Btu/lb of product processed & Refinery \\
\hline Btu/number of beds occupied & Hotel or hospital \\
\hline $\mathrm{kWh} / \mathrm{ft}^{2}$ & Lighting \\
\hline $\mathrm{kW} / \mathrm{ton}$ & Chilled water efficiency \\
\hline $\mathrm{W} / \mathrm{cfm}$ of airflow & HVAC systems \\
\hline
\end{tabular}




\section{Table 5-2 Energy Performance Metrics That Reflect Societal Impacts}

\begin{tabular}{l|l|}
\multicolumn{1}{c|}{ Metric } & \multicolumn{1}{c|}{ Purpose } \\
\hline Source Btu/ $\mathrm{ft}^{2}$ & $\begin{array}{l}\text { Captures all energy uses associated with the building, including } \\
\text { generation and distribution }\end{array}$ \\
\hline $\begin{array}{l}\text { Time Dependent } \\
\text { Valuation (TDV\$/ } \mathrm{ft}^{2} \text { ) }\end{array}$ & $\begin{array}{l}\text { Includes impact on the utility grid and the environment from time of } \\
\text { day usage, peak demand, carbon emissions, and other parameters }\end{array}$ \\
\hline $\begin{array}{l}\text { Life cycle } \\
\text { assessment }\end{array}$ & $\begin{array}{l}\text { Addresses embodied energy, disposal cost, and other cradle-to-grave } \\
\text { cost and environmental impacts }\end{array}$ \\
\hline $\mathrm{CO}_{2}$ equivalent $/ \mathrm{ft}^{2}$ & Reflects greenhouse gas emissions associated with the building \\
\hline
\end{tabular}

Simulation-based energy benchmarks, corroborated by available measured data from best-inclass high performance buildings, can be used to set national targets for all building types in all climates, ultimately leading to NZE. The benchmarks may also serve to complement or enhance current rating systems, allowing owners to promote the efficiency of their buildings and recoup the value of efficiency investments if the building is sold. Eventually the benchmarks could also support ENERGY STAR ratings, Leadership in Energy and Environmental Design (LEED) certification, and possible Passivhaus specifications for commercial buildings. Federal, state, and local governments can be encouraged to lead the way in adopting these benchmarks as formal energy targets, and progressive professional organizations such as AIA and ASHRAE may be among the first to endorse them. Best practices for tracking progress toward achieving energy performance targets throughout the construction and operations processes could be developed to ensure that actual performance is consistent with design intent (see Section 5.7).

Solutions may be pursued in all four classifications (Table 5-3).

Table 5-3 Classification of Proposed Solutions to Energy Benchmarking Challenges

\begin{tabular}{|c|c|}
\hline Classification & Proposed Solutions \\
\hline Inspirational & $\begin{array}{l}\text { - Establish specific national NZER whole-building energy use targets } \\
\text { for new construction } \\
\text { - Encourage adoption of targets for new federal and state owned } \\
\text { buildings }\end{array}$ \\
\hline Motivational & $\begin{array}{l}\text { - Collaborate with partners to develop a quantitative rating and } \\
\text { labeling framework to better recognize the highest performing } \\
\text { buildings }\end{array}$ \\
\hline Procedural & $\begin{array}{l}\text { - Provide industry with best practices for tracking achievement of } \\
\text { targets throughout the construction process and into operations } \\
\text { - Partner with existing rating and benchmarking programs to } \\
\text { standardize energy reporting requirements and simplify the process } \\
\text { of aggregating data from numerous sources. }\end{array}$ \\
\hline Practical & $\begin{array}{l}\text { - Tabulate a wide range of whole-building energy benchmark } \\
\text { values with appropriate metrics to be used for setting for near- and } \\
\text { long-term targets. } \\
\text { - Tabulate system-level energy benchmark values for establishing } \\
\text { energy budgets and detailed tracking of energy performance. }\end{array}$ \\
\hline
\end{tabular}




\subsubsection{Role of Existing DOE Programs}

DOE has several programs that can be leveraged and expanded to produce the solutions described in the preceding section:

The Commercial Reference Building models (www1.eere.energy.gov/buildings/commercial/ref_buildings.html) or the Commercial Prototype Building Models (www.energycodes.gov/development/commercial/90.1_models) developed by DOE could serve as the base models for developing analytical benchmarks in the near term. Modifications could be necessary to capture the effects of building size; geometry, occupancy patterns; alternative heating, ventilation, and air conditioning (HVAC) systems; and other key energy use drivers. Benchmark energy use data have already been developed based on the Commercial Reference Buildings in support of the 30\% and 50\% AEDGs. The AEDG benchmarks are based on modeling of hypothetical buildings instead of measured data from real buildings, but they can provide a good starting point.

DOE's EIA is responsible for implementing CBECS. EIA may consider adding data qualifiers to the survey to better identify high performance buildings, and allow more detailed statistical analysis of the energy use drivers. However, CBECS does not include enough new buildings to establish statistically significant benchmarks by building type and climate. Because the cost of conducting each CBECS is high, EIA will probably be unable to survey larger sample sizes, but a larger fraction of new buildings may be possible.

The Better Buildings Initiative, including the BBA, has great interest in ongoing tracking of commercial building energy performance, and could help to coordinate any benchmarking efforts. This could ensure the resulting data are useful to all relevant DOE programs, including those that address existing buildings.

DOE is an active partner in the Global Superior Energy Performance (GSEP) Partnership, which contributes to standardization and best practices in energy measurement and tracking protocols. This program can assist with means and methods for measuring and reporting energy use in a consistent manner.

Federal buildings will probably be among the first to adopt NZER benchmark values as targets for all new construction, although other groups may be targeted as well. BTO and FEMP could work in partnership to facilitate and support adoption of the benchmarks as the basis for target setting in federal buildings of all types.

The platform for final data collection could be integrated with existing DOE databases such as the Buildings Performance Database, the High Performance Buildings Database, the Life Cycle Inventory Database, the Standard Energy Efficiency Data (SEED) Platform, and the Technology Portal. DOE has also created a Zero Energy Buildings Database (zeb.buildinggreen.com/), including details of design features and energy use, that is part of the High Performance Buildings Database.

\subsubsection{Potential Collaborators}

Many collaborators could be needed to successfully establish meaningful energy benchmarks for high performance commercial buildings, and several key industry groups can stimulate 
benchmarking efforts for certain market sectors. An illustrative list of potential collaborators is provided in Table 5-4.

\section{Table 5-4 Potential Key Collaborators for Energy Benchmark Data Solutions}

\begin{tabular}{|c|c|c|}
\hline $\begin{array}{l}\text { Collaboration } \\
\text { Category }\end{array}$ & Collaborator Role & Key Collaborators \\
\hline \multirow[t]{5}{*}{ Data Collection } & $\begin{array}{l}\text { Submit energy use data for individual buildings } \\
\text { and portfolios into Portfolio Manager or other } \\
\text { building performance database }\end{array}$ & $\begin{array}{l}\text { EPA, building owners, energy managers, New } \\
\text { Buildings Institute (NBI), USGBC, AIA } 2030 \\
\text { Commitment }\end{array}$ \\
\hline & $\begin{array}{l}\text { Collect and provide energy use data for larger } \\
\text { groups of buildings }\end{array}$ & $\begin{array}{l}\text { Utilities, EPA, Urban Land Institute (ULI), } \\
\text { California Energy Commission, Northwest } \\
\text { Energy Efficiency Alliance (NEEA), USGBC, } \\
\text { portfolio owners }\end{array}$ \\
\hline & $\begin{array}{l}\text { Develop practical standardized disclosure } \\
\text { requirements }\end{array}$ & $\begin{array}{l}\text { BOMA, International Facility Management } \\
\text { Association (IFMA), GSEP, utilities, city and state } \\
\text { policy makers, NASEO, design professionals }\end{array}$ \\
\hline & $\begin{array}{l}\text { Implement disclosure laws and share lessons } \\
\text { learned }\end{array}$ & States, cities \\
\hline & $\begin{array}{l}\text { Provide data for weather normalization in an } \\
\text { automated form }\end{array}$ & $\begin{array}{l}\text { National Oceanic and Atmospheric } \\
\text { Administration }\end{array}$ \\
\hline \multirow[t]{2}{*}{ Metrics } & $\begin{array}{l}\text { Develop standard units for reporting utility } \\
\text { billing data }\end{array}$ & Utilities, design professionals, owners \\
\hline & $\begin{array}{l}\text { Define normalization parameters for each } \\
\text { building type }\end{array}$ & EPA, BOMA \\
\hline \multirow[t]{2}{*}{ Modeling } & $\begin{array}{l}\text { Derive modeling inputs based on statistical } \\
\text { analysis of Portfolio Manager input data }\end{array}$ & EPA \\
\hline & $\begin{array}{l}\text { Expand modeling performed for NZER feasibility } \\
\text { analysis }\end{array}$ & Pacific Gas \& Electric \\
\hline \multirow[t]{3}{*}{ Rating System } & $\begin{array}{l}\text { Adopt energy benchmarks as part of green } \\
\text { building certification requirements }\end{array}$ & $\begin{array}{l}\text { USGBC, Green Building Initiative, International } \\
\text { Living Future Institute }\end{array}$ \\
\hline & $\begin{array}{l}\text { Adopt energy benchmarks as part of ENERGY } \\
\text { STAR requirements }\end{array}$ & EPA \\
\hline & $\begin{array}{l}\text { Adopt energy benchmark and asset rating } \\
\text { programs }\end{array}$ & CEC \\
\hline \multirow[t]{3}{*}{ Deployment } & $\begin{array}{l}\text { Adopt energy benchmarks as targets for local } \\
\text { government buildings }\end{array}$ & States, municipalities \\
\hline & $\begin{array}{l}\text { Adopt energy benchmarks as targets for federal } \\
\text { government buildings }\end{array}$ & GSA and other federal building owners \\
\hline & $\begin{array}{l}\text { Adopt energy benchmarks as targets for private } \\
\text { sector buildings }\end{array}$ & Regional energy collaboratives \\
\hline
\end{tabular}

Many additional collaborators are likely to make important contributions to various phases of national efforts to improve the quality and depth of energy benchmarking data for new commercial buildings: 
- Institute for Real Estate Management

- NAIOP (also known as the Commercial Real Estate Development Association)

- Passive House Institute U.S.

- Universities

- Private sector benchmarking tool developers.

\subsubsection{Solution Timeline}

Figure 5-10 presents the proposed benchmarking solution timeline, which characterizes solutions as short term (0-3 years), medium term (3-6 years), or long term (6-15 years), and identifies relationships between solutions.

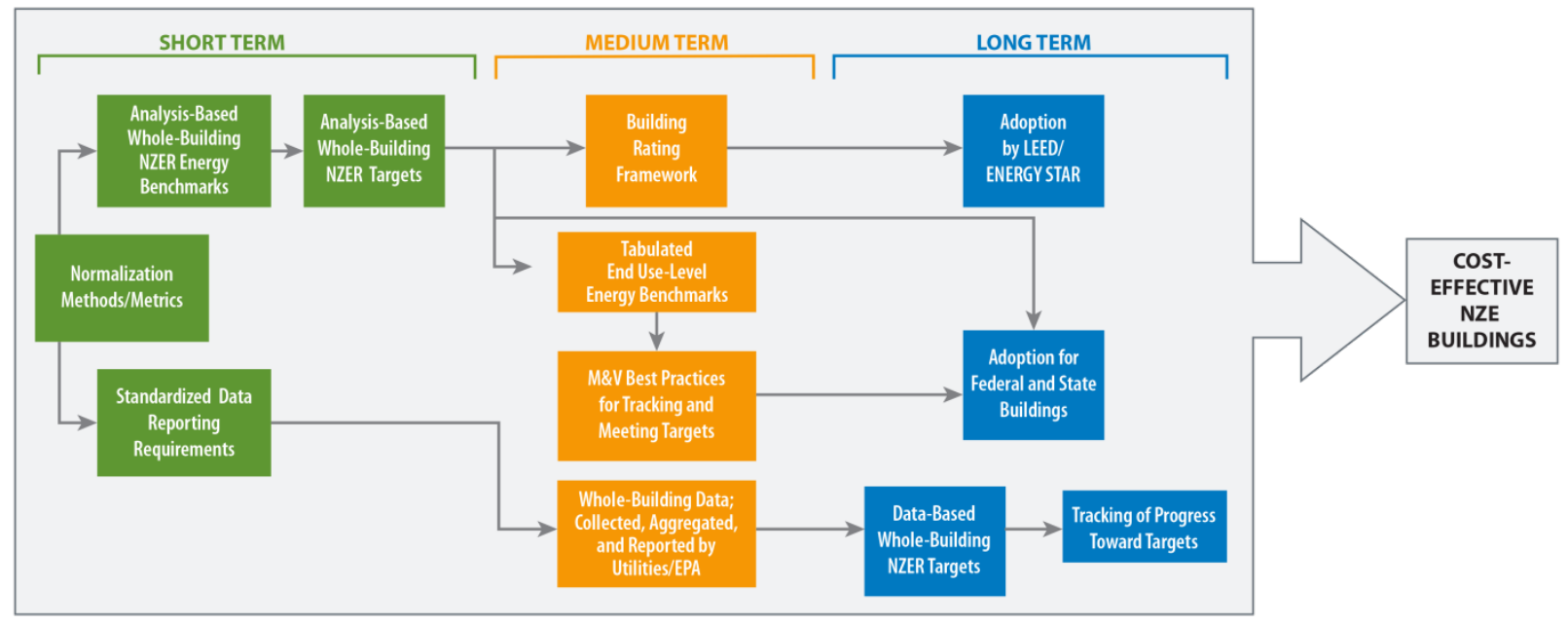

Figure 5-10 Proposed energy benchmark data solution timeline

\subsection{Focus Area \#2: Enhanced Modeling Tools}

Enhanced modeling capabilities may be needed to support financial decision-making, wholebuilding design, analysis of new technologies, and operational and behavioral influences on energy use throughout the building life cycle. Energy modeling tools also could more effectively integrate with building information modeling and other building performance analysis tools to enable timely analysis of energy- and nonenergy-related parameters. Modeling tools and data could be extended to the financial decision-making, value engineering, construction, and commissioning processes and then used in ongoing building operations and M\&V. This may be particularly important as buildings adopt more sophisticated integrated systems and controls to achieve higher performance levels and integrate renewable energy systems. Modeling can be especially challenging for small buildings because the design budget can be very limited and complex tools are impractical. 


\subsubsection{Critical Needs}

Challenges related to energy modeling can be especially difficult to overcome when NZER performance is targeted. A whole-building design process is required, along with consideration of a broader range of efficiency options, including new technologies that are often incompatible with the inputs allowed by current tools. Measure-by-measure analysis could be replaced by more complex yet rapid optimization techniques without sacrificing accuracy or ease of use. Modeling tools may begin to provide a range of savings with probability or uncertainty margins that reflect the wide range of possible use patterns and building loads once the building is occupied. Advanced lighting systems, plug loads, and specialized equipment and systems are particularly difficult to model accurately using current tools. Easier-to-use modeling tools may be needed during the early design stages to narrow the set of options, transitioning to more sophisticated tools for detailed design. Methods for adjusting models based on actual operating parameters and occupant behavior are also helpful to better understand discrepancies between modeled and actual performance. Better predictive modeling capabilities can help facility managers adjust building operations based on weather conditions and expected use patterns to achieve optimal performance while maintaining occupant comfort and meeting other functional needs of the building. Modeling tools must be able to import actual energy consumption data and automatically determine whether a building complies with common code requirements. Highly simplified methods could allow small building owners and contractors to reduce transaction costs and bypass detailed modeling altogether.

Figure 5-11 links each need with its core audience and identifies the design and construction stages that would benefit most if it is successfully addressed.

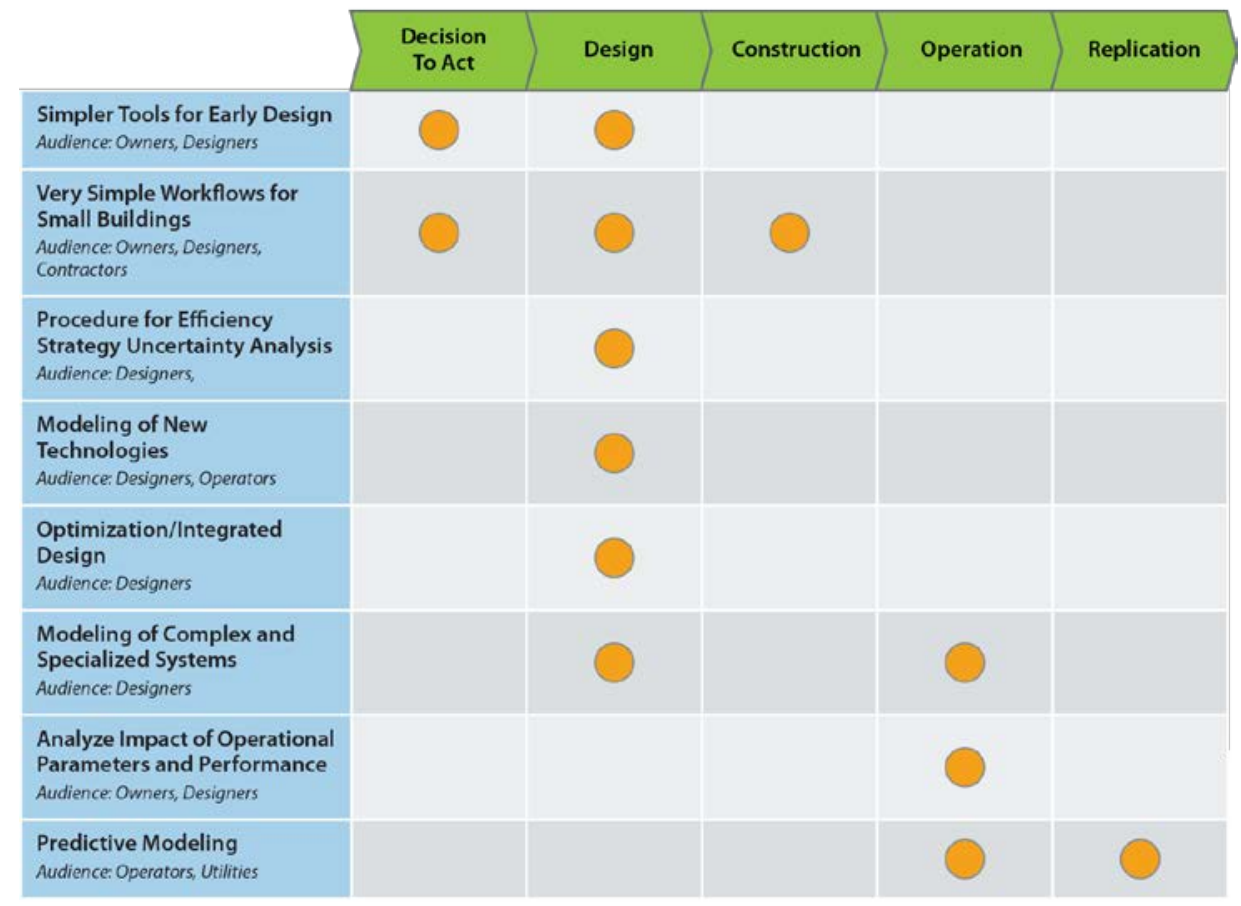

Figure 5-11 Linking critical energy modeling needs to audience and impact 


\subsubsection{Strategic Approach}

BTO's ET Program pursues advancements in the capabilities, speed, and accuracy of building energy modeling engines, but CBI can support, inform, and enhance those efforts in several ways (see Figure 5-12).

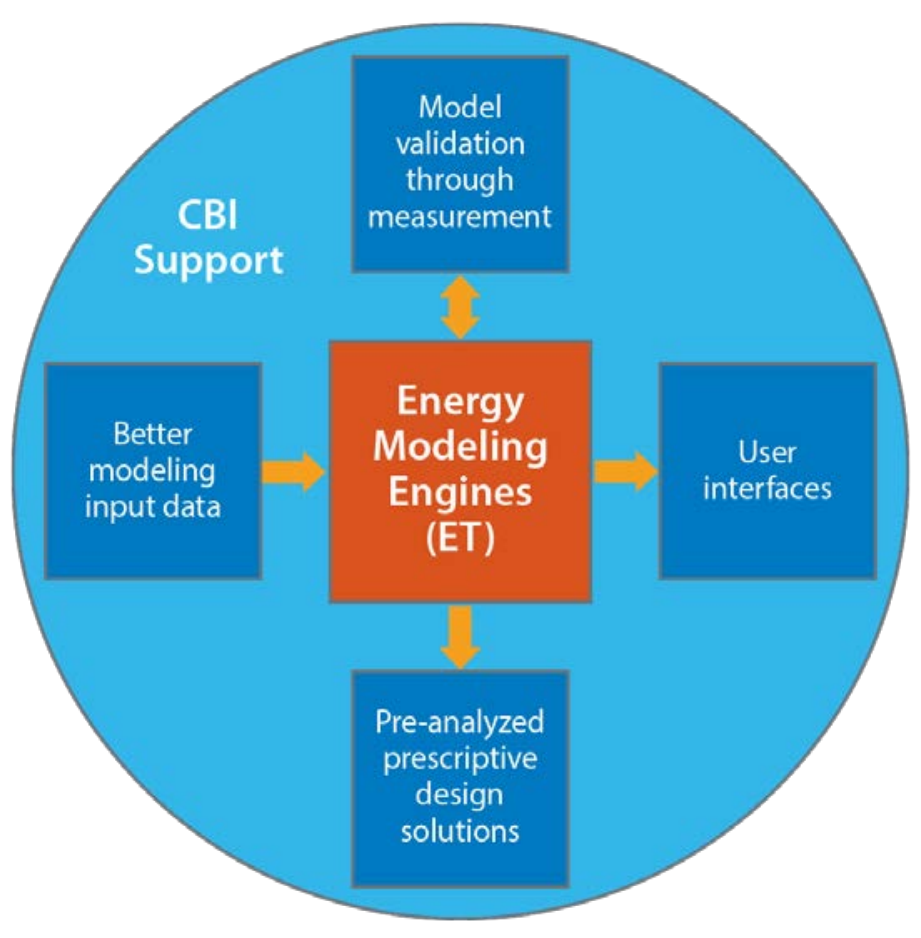

Figure 5-12 Four categories of CBI support for modeling tool engines developed by the BTO ET program

- Better design input data. Standardized input data for building energy models could be developed in consultation with industry to improve the usefulness of modeling tools during early design. As discussed in Section 5.6, cost data can be collected from a number of sources; these data can be packaged into a standard set of libraries that can be included with tools such as OpenStudio, COMFEN (commercial building fenestration design tool), and Simergy. Cost data are helpful for early design tradeoffs and later for detailed optimization analysis. Most users would value the ability to replace standard cost data with their own actual costs based on vendor quotes or previous projects. The following categories of standard cost data could be addressed:

- First cost (purchase, installation, commissioning)

- O\&M costs

○ M\&V costs

- Replacement costs

○ Soft costs (design, vendor selection). 
Modeling accuracy can be enhanced and more confidence can be gained in performance predictions of new technologies through controlled laboratory and field testing of energy using equipment and key integrated building systems. An iterative process is often needed between modeling and testing to ensure that modeling algorithms include all relevant inputs and produce realistic outputs. Building system evaluations under realistic conditions present ongoing challenges as new technologies and integrated systems are developed, because test equipment and test bed costs are high, and evolving building equipment designs can make previous test results (and even test methods) obsolete. Thus, such testing may be performed by a variety of partners depending on the situation, including equipment manufacturers, building owners, national laboratories, and other partners. AHRI and the DOE's Appliance and Equipment Standards Program could be key partners for improving standard test procedures for mechanical and electrical equipment, and ASTM is the leader in standard test methods for building envelope components.

DOE has test bed facilities under development that can provide enhanced capabilities for assessing these systems beyond standard test requirements. Installed equipment performance often needs to be measured under a range of operating conditions to predict its long-term energy use. This is especially true of specialized equipment used in restaurants, healthcare facilities, and laboratories. Part-load performance of common HVAC equipment can also be measured under a variety of conditions to improve the default performance curves in energy models.

A study of occupant behavior (e.g., use of shading, thermostats, office equipment) and maintenance practices could be conducted to better understand the statistical distribution of operating conditions that buildings are likely to experience, and how those behaviors influence energy use. This information would allow modeling tools to better quantify the uncertainty in energy savings predictions caused by occupant interactions with buildings. Analysis of occupant behavior is also valuable for developing accurate predictive modeling capabilities. This activity is strongly connected to the need for understanding and characterizing operational deficiencies described in Section 5.7, and could be performed as part of a single, coordinated effort.

- Model validation through measurement. The performance of new technologies in actual buildings is often affected by unexpected interactions between systems and occupants. Promising new systems and products can be continually evaluated through direct measurements in actual buildings and in test beds. The results would inform the mathematical algorithms used in energy models to ensure realistic predictions of energy savings for new and innovative efficiency measures soon after they become available.

Complex system interactions can be studied in actual buildings to help validate and improve modeling algorithms related to daylighting, building control systems, refrigeration systems, ground coupling, ventilation, and infiltration. Field test data are also valuable for developing predictive modeling capabilities and practical model calibration techniques. Field evaluation of high performance buildings has long been a high priority for building scientists, and its importance will continue to grow as more buildings approach NZER. 
Enhanced capability to automatically adjust building models in real time based on actual building performance, operations, and weather conditions could be developed. This would allow predictive modeling that can help operators anticipate high peak demand periods, opportunities for free heating or cooling, or imminent equipment failures, and take appropriate action. In addition, automated model calibration during the construction, commissioning, and post-occupancy stages can help ensure that design targets are met in practice. Modeling-supported building-level fault detection could be developed to determine when actual building performance deviates beyond the range predicted by simulations, facilitating prompt action to correct the situation and minimize energy waste. Similar work proposed in Section 5.7 could be leveraged and coordinated as a single integrated effort.

- Prepackaged design solutions. In general, the design budgets for smaller buildings cannot support detailed modeling and design tradeoff analysis. For these situations, a large number of simulations can be run across a wide range of building types and climates, leveraging the supercomputing capabilities and expert modeling skills available at DOE's national laboratories. Results can be tabulated and regression analysis can be performed on the data to develop relatively simple energy use estimations based on very few input parameters. A Web-based interface can be developed to allow simple, straightforward analysis of energy efficiency options, while achieving most of the accuracy of an expensive whole-building model. A variety of standard design packages can be produced based on building type, efficiency target, climate, HVAC system type, and use patterns. These prepackaged design solutions could benefit small building owners and designers who want to achieve aggressive energy savings targets, including NZER, but do not have the resources to perform detailed, iterative design tradeoffs.

- User interfaces. There is still a strong need for better graphical user interfaces to enable various categories of designers to use the EnergyPlus analysis engine at different stages in the building life cycle. Some graphical user interfaces for EnergyPlus are available; however, their real or perceived limitations have made widespread uptake challenging. New graphical user interfaces for EnergyPlus are scheduled for release in the near term. These will have increased capabilities that make the EnergyPlus engine more accessible to a wider range of users. In the long-term, more flexible modeling interfaces may be created to allow users to tailor the level of sophistication to their needs and capabilities. Architects, engineers, and other stakeholders could be consulted in the creation of sample requirement specifications geared according to the needs of their sector.

Extensive libraries of building characteristics, costs, and equipment schedules are currently being developed for use during the early stages of design, enabling comparative analysis to inform design decisions. Improved post-processing capabilities can also be developed to provide simplified summary results that can be easily understood by a wide range of users, and a platform can be established for sharing modeling results with others in a standard format.

Proposed solutions in the modeling focus area are mostly procedural and practical in nature. These possible solutions and their projected timeframes are summarized in Table 5-5. 


\section{Table 5-5 Classification of Possible Solutions to Modeling Tool Challenges}

\begin{tabular}{|l|l|}
\hline \multicolumn{1}{|c|}{ Classification } & \multicolumn{1}{c|}{ Proposed Solutions } \\
\hline Inspirational & $\begin{array}{l}\text { - Develop outreach materials that use modeling to communicate the value and } \\
\text { feasibility of high-performance and NZER buildings }\end{array}$ \\
\hline Motivational & $\begin{array}{l}\text { - Create a platform for sharing building energy modeling results and } \\
\text { lessons learned }\end{array}$ \\
\hline Procedural & $\begin{array}{l}\text { - Improve model inputs and algorithms by performing laboratory and field } \\
\text { testing of high performance equipment under part-load and off-design } \\
\text { conditions, as well as integrated system configurations } \\
\text { - Objectively characterize the energy use of specialized equipment and plug } \\
\text { loads under a range of operating conditions } \\
\text { - Support model algorithm development for complex system interactions } \\
\text { through field testing } \\
\text { - Characterize typical occupant behavior, operation, and maintenance practices } \\
\text { - Define performance characteristics of new technologies and design strategies } \\
\text { and improve the ability to model them }\end{array}$ \\
\hline $\begin{array}{l}\text { - Develop simple web-based tools for early design trade-offs by non-experts } \\
\text { - Create pre-packaged design solutions for a wide range of building types and } \\
\text { performance targets } \\
\text { - Automate real-time calibration, fault detection, and predictive modeling to } \\
\text { address operational deficiencies } \\
\text { - Expand capabilities of user interfaces for diverse audiences and applications }\end{array}$ \\
\hline Practical
\end{tabular}

\subsubsection{Role of Existing DOE Programs}

DOE has several programs that can be leveraged and expanded to produce the solutions described in the preceding section:

BTO's Emerging Technologies (ET) Program funds most of the energy modeling tool development work related to the core capability, accuracy, and speed of EnergyPlus. Extensive interactions can ensure that equipment testing, operating characteristics, and whole-building performance data are collected in a manner and format that allows direct integration into the underlying software architecture. The EnergyPlus team can help identify the inputs and calculations that currently have the greatest uncertainty, and that require laboratory and field studies to improve the predictive capabilities of the modeling software. Documentation of improvements to EnergyPlus could allow other software developers to incorporate similar upgrades to private sector modeling tools.

OpenStudio is an open-source set of software tools designed to facilitate the use of EnergyPlus for building energy analysis. It is adaptable to the needs of different industry sectors, and enhances the abilities of users with varying levels of expertise to model buildings quickly and accurately. Other modeling tools such as Radiance play a significant role in enabling analysis and optimization of some of the more critical integrated systems (e.g., operable shading and daylighting at various stages in the design process). The DOE software development teams are responsible for enhancing existing tools and creating the optimization routines, predictive modeling, automated calibration, and diagnostic capabilities necessary for successful implementation of CBI programs that target new construction. 
The Commercial Buildings Partnerships (CBP) Initiative

(www1.eere.energy.gov/buildings/commercial/cbp.html) and other industry partnership programs provide excellent platforms for collaborating with industry to obtain detailed field test data and pilot new software features. The BBA member organizations could be important initial users of any new modeling capabilities, and can help guide improvements to the usability and post-processing features of DOE's energy analysis tools.

The BTO Appliance and Equipment Standards group can help to standardize test protocols for equipment that will result in meaningful and objective input data to accurately model energy use in real buildings. Modified standards may be needed to put new technologies on a level playing field with more common equipment. New standards could be developed for specialized equipment for which standard test methods and data reporting requirements have not been established.

\subsubsection{Potential Collaborators}

A number of external collaborators can help develop and test the planned modeling tool improvements. Their possible roles are summarized in Table 5-6.

Table 5-6 Potential Key Collaborators for Enhanced Modeling Tool Solutions

\begin{tabular}{|c|c|c|}
\hline $\begin{array}{l}\text { Collaboration } \\
\text { Category }\end{array}$ & Collaborator Role & Key Collaborators \\
\hline \multirow[t]{2}{*}{ Software } & Implement modeling tool improvements & Software developers, design professionals \\
\hline & $\begin{array}{l}\text { Deploy innovative modeling techniques } \\
\text { and tools }\end{array}$ & $\begin{array}{l}\text { International Building Performance Simulation } \\
\text { Association (IBPSA), universities, training centers }\end{array}$ \\
\hline Automation & $\begin{array}{l}\text { Integrate real-time calibration and predictive } \\
\text { modeling }\end{array}$ & $\begin{array}{l}\text { Automated facility management companies, } \\
\text { utilities, engineers, energy analysts }\end{array}$ \\
\hline \multirow[t]{2}{*}{ Standardization } & Standardize communications and data protocols & $\begin{array}{l}\text { Commercial Energy Services Network (COMNET), } \\
\text { ASHRAE }\end{array}$ \\
\hline & $\begin{array}{l}\text { Improve and standardize test methods for } \\
\text { specialized equipment and new technologies }\end{array}$ & $\begin{array}{l}\text { American National Standards Institute (ANSI), } \\
\text { ASHRAE, manufacturers }\end{array}$ \\
\hline User Interfaces & $\begin{array}{l}\text { Assist with the design and testing of user } \\
\text { interface improvements }\end{array}$ & $\begin{array}{l}\text { Architects, engineers, energy modelers, utilities, } \\
\text { energy analysts }\end{array}$ \\
\hline
\end{tabular}

\subsubsection{Solution Timeline}

Figure 5-13 presents a possible timeline for recommended modeling tool enhancements, characterizing solutions as short term ( $0-3$ years), medium term (3-6 years), or long term (6-15 years), and identifying relationships between solutions. 


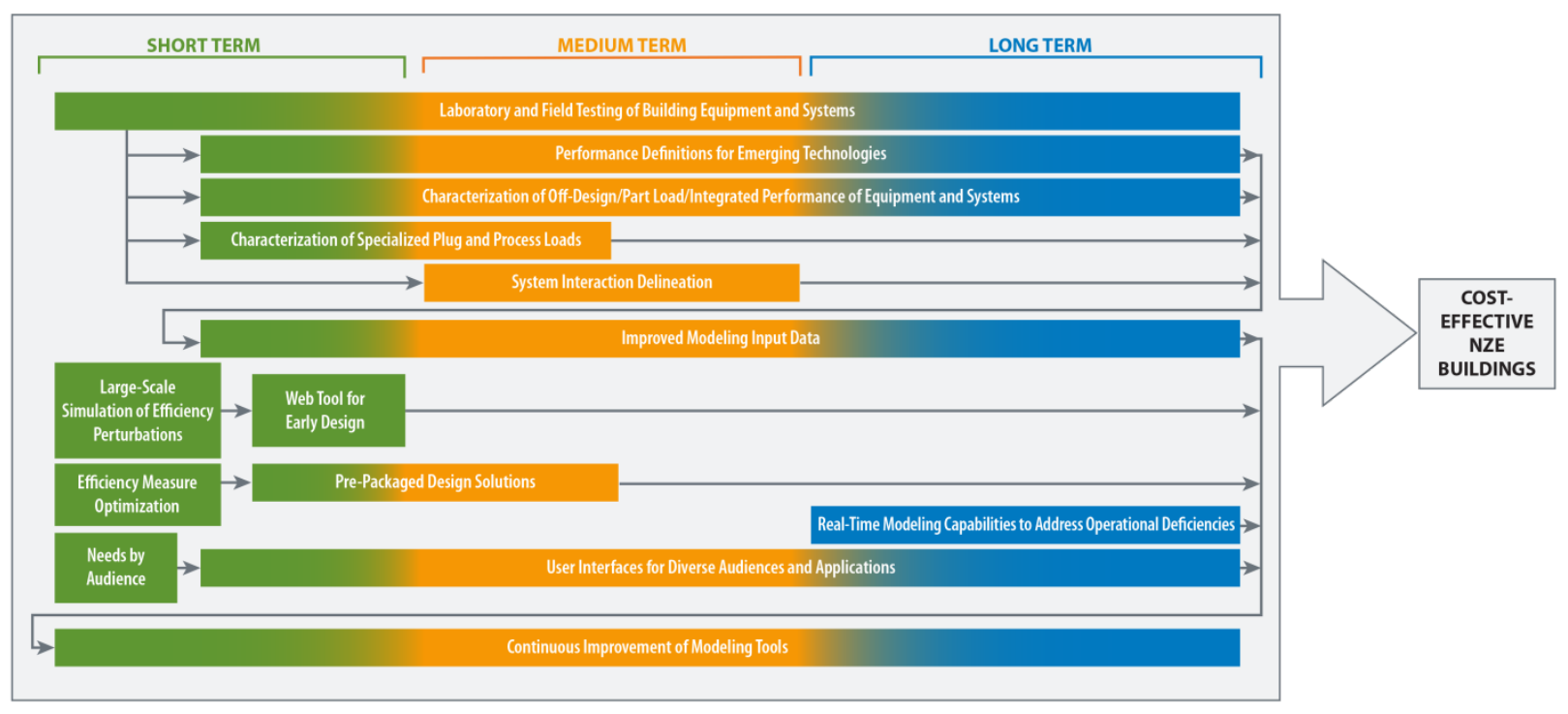

Figure 5-13 Proposed enhanced modeling tool solution timeline

\subsection{Focus Area \#3: Better Cost Data}

Cost data are critical to all phases of commercial building design and construction. Conventional design and construction costs are highly variable; there is an overall need for cost data analysis methods that can support consistency in cost estimation and improved methods for managing costs during the design and construction process. Better cost data may be needed to:

- Make a business case for high performance design packages to help building owners and design teams incorporate efficiency into project budgets.

- Inform the analysis of building system interactions and the cost and performance tradeoffs associated with energy efficiency technologies and strategies.

- Address the threat that value engineering poses to the implementation of energy efficiency technologies and strategies.

- Estimate the potential reduction in "soft costs" that can be achieved using integrated design tools, lean construction methods, and performance based procurement.

Better component-, system-, and whole building-level cost data and resources can help support these types of analysis and decision making. Modeling tools can play an important role in meeting this need (see Section 5.5). Better cost data and resources can greatly increase the potential impact of future integrated resources, such as case studies that emphasize economic feasibility (see Section 5.8).

\subsubsection{Critical Needs}

To enable informed and timely decision making throughout design and construction across the commercial buildings sector, it is important for new cost data and methods to: 
- Facilitate early design decision making. Decision-makers and designers would benefit from cost data and system-level cost estimating approaches that can enable them to make well-informed preliminary design decisions. High level (system-level as opposed to component-level) cost data that holistically capture the economic impacts of design decisions can enable energy efficiency technologies and strategies to be evaluated early in the design process. First cost represents an important—-but not the only—cost data point. Several other possible cost impacts are relevant:

- What is the operational cost impact of an efficiency measure?

- Will implementation of the measure allow HVAC equipment downsizing?

- How does the measure influence peak load and demand response?

- Will upgrades to the electrical system be required?

- Are any building structural impacts associated with measure implementation?

- What effect do rebates and incentives have on measure cost?

- Be statistically significant. Costs vary from project to project, often dramatically, based on local labor and material costs and the purchasing power of the owner or contractor. Accordingly, for a cost dataset to be applicable to a wide range of projects (with variations in building type, location, vendor agreements, etc.), it may need to contain data from a significant number of projects that collectively reflect the realistic variations in project parameters. To collect a statistically significant set of cost data for energy efficiency technologies and strategies, contributions from many partners will likely be needed. To address this need, the potential contradiction between statistical significance and voluntary collection presents a challenge.

- Be standardized and validated. With this "crowd-sourcing" mechanism for cost data collection, data standardization and validation strategies and workflows can become critical. Carefully defined data collection procedures can help to standardize data format and content, reducing the burdens for data validation and collection to the extent possible. Data validation procedures can be used to filter data according to the quality of the source, the measurement approach, and other criteria. Because large quantities of cost data may be collected and validated, these procedures may need to be highly automated.

- Be stored and maintained. Infrastructure could be developed to allow large-scale cost data to be collected, stored, validated, shared, applied, and maintained. The costs associated with building efficiency technologies and strategies are constantly changing; it is important for any solution to cost data collection, storage, and distribution to be dynamic enough to keep pace with the rate of change. Partnering with private sector organizations that have done significant work in the area of data storage and maintenance may help in a national effort to address this need.

Figure 5-14 links each need with its core audience and identifies the design and construction stages that would benefit most if it is successfully addressed. 


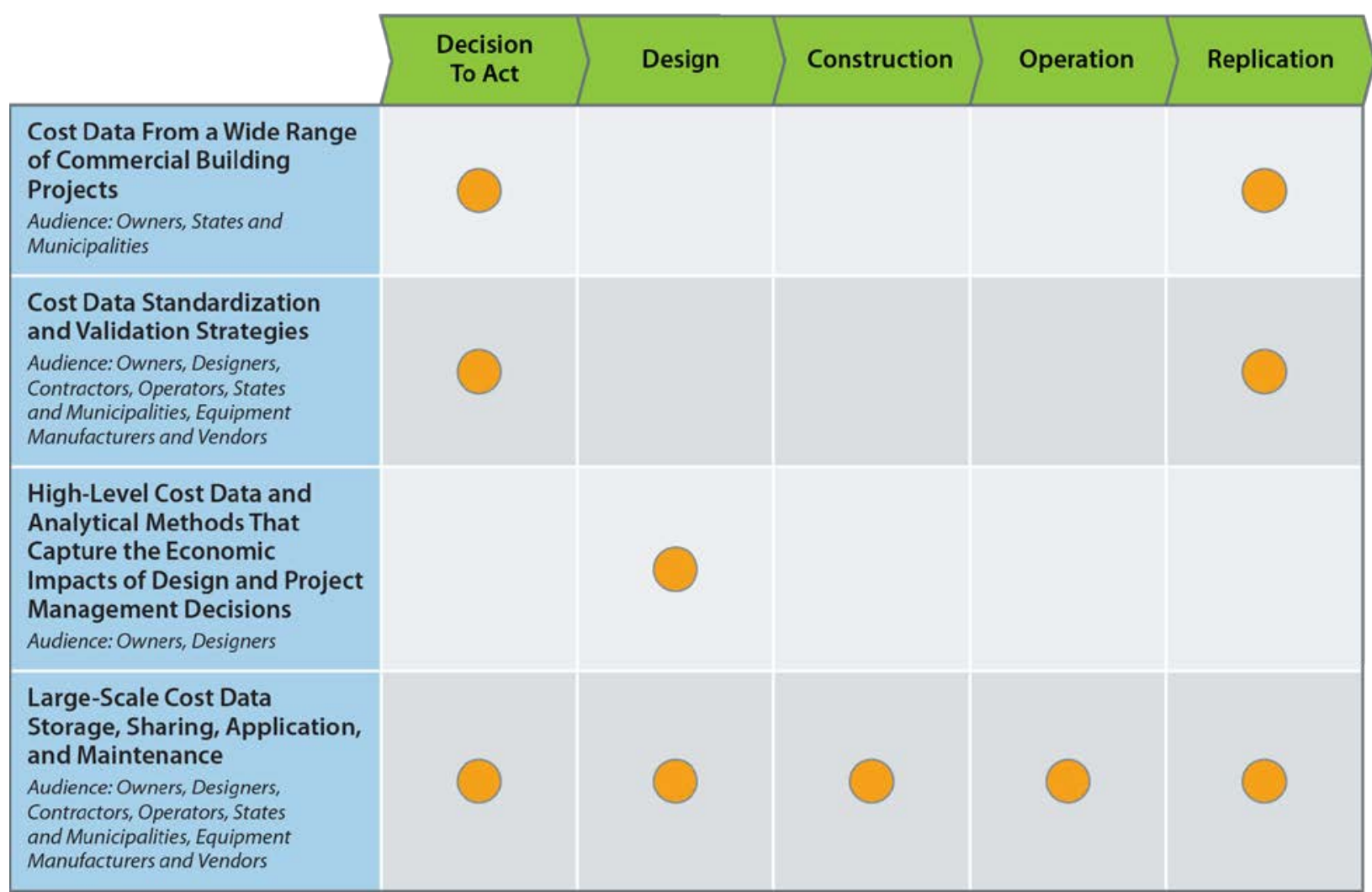

Figure 5-14 Linking critical cost data needs to audience and impact

\subsubsection{Strategic Approach}

Compiling and managing a cost dataset that characterizes energy efficiency technologies and strategies completely enough to facilitate early design decision-making across the commercial building sector would be a serious undertaking that would be impractical for one organization to take on alone. An approach is recommended by which DOE might develop the infrastructure required to collect, store, share, validate, apply, and maintain such a dataset, and then establish partnerships through which the data can be collected and maintained. The recommended strategic approach can be defined as follows:

- Define the metrics and processes that will shape the cost dataset, and help customers understand how to manage cost while stimulating innovation. The ultimate goal of the energy efficiency technology and strategy cost dataset would likely be to facilitate decision-making in the early stages of building design. To this end, cost data metrics could be developed to allow accurate and consistent comparisons among the merits of potential design solutions; the resultant metrics would reflect the set of cost data parameters that inform early design decisions (first costs, maintenance costs, replacement costs, system interactions, structural implications, electrical system requirements, etc.) and leverage the institutional knowledge of the AECO community (practical considerations for implementation, design rules of thumb, order of magnitude costs, etc.). A preliminary assessment of industry cost data collection and application workflows could inform this effort. 
Once cost data metrics are defined, processes could be developed to standardize and facilitate data collection, validation, and application. Metrics and processes would account for potential barriers associated with data confidentiality and disclosure, including the link between project-specific cost data and competitive advantage. Recognizing that most organizations would have limited time and resources to build and maintain the cost dataset, it will be important for metrics and processes to address the importance of reducing the near- and long-term burdens associated with data collection and validation. Because improving high level, early design decision-making would likely be the primary intended use of the dataset, cost metrics and processes may need to emphasize the collection of building- and system-level data. However, component-level cost data are still likely to play an important role in making early design decisions, especially with respect to equipment make and model selections.

- Build relationships with key deployment partners. Establishing partnerships to collect and maintain the cost dataset over the long term would be critical to the success of this approach. This engagement of key deployment partners (building owners, AECOs, and equipment manufacturers) will help ensure that the cost data is continually updated and vetted, leading to well-informed early design decisions across the commercial buildings sector.

- Develop and pilot a publicly accessible cost database. A publicly accessible cost database could be developed and piloted. The pilot stage could allow deployment partners to evaluate the metrics and workflows through which the database is accessed and used. Deployment partner feedback can be used to refine workflows, and ultimately, to decide whether it is feasible, given the established partnerships, to collect and maintain cost data at a scale that can improve early design decision making across the commercial building sector. Post-processing capabilities can be added to allow analysis of the average and statistical distributions of typical costs.

- Investigate alternative methods for cost analysis. First costs for energy efficiency technologies and strategies are dynamic and difficult to predict. A cost-targeting methodology could be developed that can address this issue by inverting the problem. By simulating the performance of a technology for a given combination of building type and climate zone, and overlaying that performance onto a specified economic requirement ( 5 year simple payback, neutral TLCC after 10 years, etc.), a threshold cost point can be established for cost effectiveness. To provide context for cost-effectiveness thresholds, strategies for first cost collection can be used to compare the resultant thresholds to current industry cost ranges. The methodology can maximize the ability of designers to customize recommendations according to project-specific economics. Cost-effectiveness thresholds for energy efficiency measures can give contractors a reference point in negotiating with architects and subcontractors, and help move the market in the direction of incorporating efficiency at lower first cost.

- Identify best practices for controlling capital and management costs. Several industry leaders in energy efficiency have developed workflows that allow high performance and NZE buildings to be designed, constructed, and operated cost effectively; unfortunately, the expertise embodied in those workflows currently has limited penetration in the commercial building sector. Cost control best practice 
guidance could be developed for key industry users (building owners, architects, designers, energy champions, etc.) to incorporate into their everyday workflows. By demonstrating to the commercial new construction market how to combine advanced technologies, design methods, and project management approaches into an overall efficiency package that can be implemented at minimal incremental cost, the domain of NZE design and construction can be expanded from the niche market of showcase projects to the commercial new construction mainstream. Furthermore, best practices associated with NZE design and construction could be applicable to the high performance building market in general, expanding the potential realm of impact of this project from the NZE buildings market to the commercial buildings sector as a whole.

Solutions may be pursued in all four classes (Table 5-7).

Table 5-7 Classification of Possible Solutions to Cost Data Challenges

\begin{tabular}{|l|l|}
\hline \multicolumn{1}{|c|}{ Classification } & \multicolumn{1}{|c|}{ Proposed Solutions } \\
\hline Inspirational & $\begin{array}{l}\text { - Demonstrate the viability of a cost database that will enable accurate } \\
\text { and consistent evaluation of energy efficiency technologies and } \\
\text { strategies } \\
\text { - Document use cases to demonstrate the value of the database to the } \\
\text { early design process }\end{array}$ \\
\hline Motivational & $\begin{array}{l}\text { - Develop a business case to motivate building owners, AECOs, } \\
\text { equipment manufacturers, and equipment vendors to adopt a } \\
\text { community-based approach to cost data collection }\end{array}$ \\
\hline - Define a cost estimation procedure that systematically accounts for \\
system interactions and tradeoffs \\
- Specify the set of cost data parameters that impact design decisions \\
- Define cost metrics that can facilitate accurate and consistent \\
comparison of energy efficiency technologies and strategies \\
- Develop cost data collection procedures that standardize data \\
content and format \\
- Develop cost data validation procedures appropriate for the data \\
collection partnerships, and data collection and storage workflows \\
\hline - Define the requirements for a publicly accessible cost database that \\
facilitates early design decision-making \\
- Develop training materials to guide the collection, application, and \\
maintenance of the cost dataset
\end{tabular}

\subsubsection{Role of Existing DOE Programs}

DOE has several programs that can be leveraged and expanded to produce the recommended solutions described in the preceding section:

Database development is likely to play a key role in collecting, storing, and sharing cost data. A number of DOE programs can be leveraged from a database development perspective, including the High Performance Buildings Database, the Life Cycle Inventory Database, the SEED Platform, the Technology Portal, and the COMFEN tool. A key product of the SEED Platform is a database taxonomy. Data collection standardization (through the development of technology data entry forms) and "crowd-sourcing" have been explored in detail as part of the Technology 
Portal program. The COMFEN project is currently working with users to improve and expand on the value of a façade construction cost database; considerations include crowd-sourced data collection. Lessons learned from these programs can inform the development of the database architecture, as well as the metrics and procedures that would shape the cost dataset.

As mentioned previously, establishing industry partnerships through which an impactful cost dataset can be compiled and maintained may be critical to the success of this strategic approach. DOE could leverage its industry contacts to develop the necessary partnerships. Programs such as CBP, the BBA, the Performance Based Value Engineering Program, the Open ADR Alliance, the Better Buildings Challenge, and industry partnership programs, including the High Performance Green Building Partnership Consortia, could prove valuable in the effort to secure the necessary collaborations.

\subsubsection{Potential Collaborators}

Many collaborators might be necessary to successfully develop an energy efficiency technology and strategy cost database that can improve the early design decision-making process across the commercial buildings sector. Potential key collaborators and their roles are presented in Table 5-8.

\section{Table 5-8 Potential Key Collaborators for Cost Data Solutions}

\begin{tabular}{|c|c|c|}
\hline Collaboration Category & Collaborator Role & Key Collaborators \\
\hline $\begin{array}{l}\text { Developing Cost Data } \\
\text { Collection Infrastructure and } \\
\text { Workflows }\end{array}$ & $\begin{array}{l}\text { Guide the development of metrics, procedures, } \\
\text { and workflows that will define the cost } \\
\text { data reporting and collection framework. } \\
\text { In particular, provide insight into the } \\
\text { barriers associated with data collection and } \\
\text { dissemination, especially those that relate to } \\
\text { data confidentiality }\end{array}$ & $\begin{array}{l}\text { - RS Means, cost estimating firms, } \\
\text { publications and research entities that } \\
\text { gather industry feedback annually }\end{array}$ \\
\hline $\begin{array}{l}\text { Specifying the Cost Data } \\
\text { Parameters that Impact } \\
\text { Design Decisions And Project } \\
\text { Budget Specification }\end{array}$ & $\begin{array}{l}\text { Identify the cost parameters that influence } \\
\text { project workflows, highlighting how each } \\
\text { parameter informs and influences design and } \\
\text { construction decisions }\end{array}$ & $\begin{array}{l}\text { - Architects, engineers, general } \\
\text { contractors, owners, BOMA, cost } \\
\text { estimating firms }\end{array}$ \\
\hline $\begin{array}{l}\text { Defining Cost Metrics } \\
\text { Appropriate for Early Design } \\
\text { Decision Making }\end{array}$ & $\begin{array}{l}\text { Specify the practical requirements for a cost } \\
\text { metric (e.g. life cycle cost, present value) that } \\
\text { accurately captures the cost data parameters } \\
\text { that affect decision making and is meaningful to } \\
\text { all members of the project team }\end{array}$ & $\begin{array}{l}\text { - Owners, developers, AECOs, BOMA, } \\
\text { cost estimating firms }\end{array}$ \\
\hline \multirow[t]{2}{*}{$\begin{array}{l}\text { Community-Based Cost } \\
\text { Data Collection }\end{array}$} & $\begin{array}{l}\text { Advocate for the benefits of community-based } \\
\text { cost data collection through demonstration of } \\
\text { the business case }\end{array}$ & \multirow{2}{*}{$\begin{array}{l}\text { Owners, developers, AECOs, equipment } \\
\text { manufacturers and vendors, GSA, } \\
\text { states, municipalities, cost estimating } \\
\text { firms }\end{array}$} \\
\hline & Collect and maintain the cost dataset & \\
\hline
\end{tabular}


Other potential collaborators for cost data solutions include:

- NBI

- Underwriters Laboratories, Inc.

- Northeast Energy Efficiency Alliance

- Real estate managers, large companies, and institutions

- Financial organizations and appraisers.

\subsubsection{Solution Timeline}

Figure $5-15$ presents a possible cost data solution timeline, which characterizes recommended solutions as short term ( $0-3$ years), medium term (3-6 years), or long term (6-15 years), and identifies relationships between solutions.

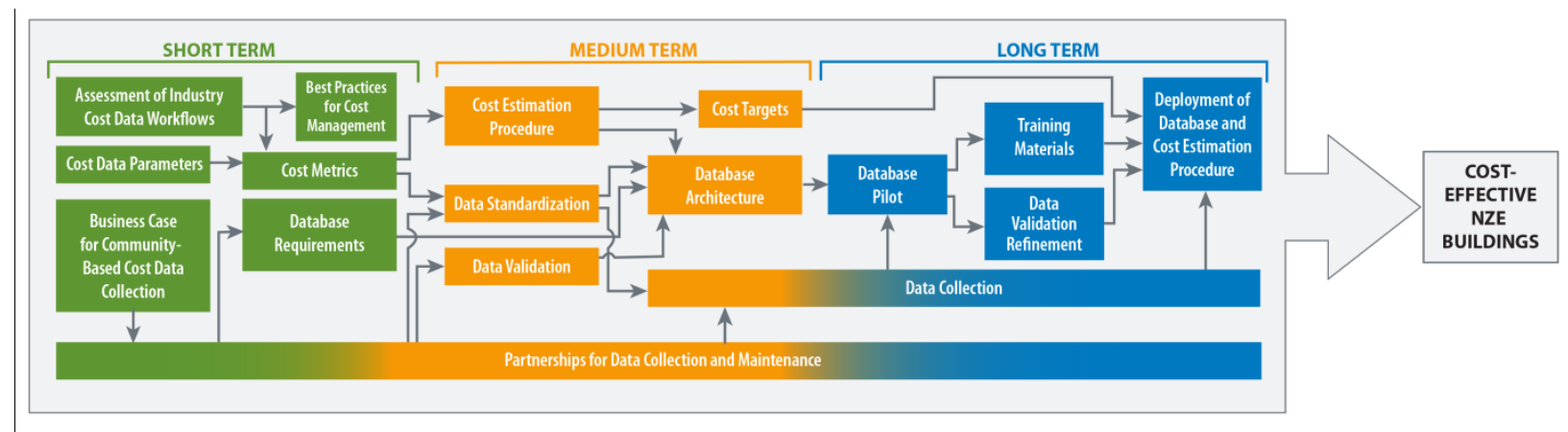

Figure 5-15 Proposed cost data solution timeline

\subsection{Focus Area \#4: Commissioning and Operational Strategies}

Buildings designed for high performance often do not achieve the expected performance level once occupied, frequently because of insufficient or ineffective commissioning practices, incorrect building operations, and occupants who have not been properly educated about how to optimally use building features. As buildings approach NZER, more complex technologies and control systems could present additional challenges to building operators and occupants. A deliberate approach to design team-operator-occupant teaming is important for connecting design intent and decision-making to actual construction, building operations, and building-occupant interactions so that building performance can be matched with design goals, without incurring undue costs.

\subsubsection{Critical Needs}

More effective commissioning and operational protocols can inform commissioning agents, building operators, facility managers, and occupants about how to verify and sustain optimal building performance, and these procedures can influence changes to standard industry practice. Operating protocols for new technologies and complicated control systems may require special attention. It is important for equipment installers and commissioning agents to verify that all components are fully functional and work together under a range of operating conditions. Facility managers can use similar guidance and training so they understand how to track performance over time and make necessary adjustments to control strategies. Building operators 
could partner with industry to develop procedures to ensure these tasks are carried out properly. For small building owners without dedicated facility managers, or large building owners with staff who are less experienced with energy-efficient building systems, these issues can be mitigated through robust design, building automation systems, self-diagnostics, or regular recommissioning by a knowledgeable professional. Enhanced fault detection for individual systems (ideally installed by equipment manufacturers) and whole buildings (through predictive modeling, as discussed in Section 5.5) could allow quick identification and correction of problems before a significant amount of energy is wasted. Informational resources can help demonstrate the financial impacts of wasted energy from suboptimal building operations or incorrect equipment installation. Education for occupants and devices that support occupant engagement are especially important, both for operating major building systems and for controlling local lighting and plug loads.

Figure 5-16 links each need with its core audience and identifies the design and construction stages that would benefit most if it is successfully addressed.

\begin{tabular}{|c|c|c|c|c|c|}
\hline & $\begin{array}{c}\text { Decision } \\
\text { To Act }\end{array}$ & Design & Construction & Operation & Replication \\
\hline \multicolumn{6}{|l|}{$\begin{array}{l}\text { Contractual Guidance for } \\
\text { Commissioning } \\
\text { Audience: Owners }\end{array}$} \\
\hline \multicolumn{6}{|l|}{$\begin{array}{l}\text { Robust Building Design } \\
\text { Strategies } \\
\text { Audience: Designers }\end{array}$} \\
\hline \multicolumn{6}{|l|}{$\begin{array}{l}\text { Improved Equipment } \\
\text { Self-Diagnostics } \\
\text { Audience: Designers, Operators }\end{array}$} \\
\hline \multicolumn{6}{|c|}{$\begin{array}{l}\text { Education About Financial } \\
\text { Consequences of Operational } \\
\text { Failures } \\
\text { Audience: Owners, Designers, } \\
\text { Contractors, Operators }\end{array}$} \\
\hline \multicolumn{6}{|c|}{$\begin{array}{l}\text { Commissioning Guidelines } \\
\text { for Advanced Systems } \\
\text { Audience: Operators }\end{array}$} \\
\hline \multicolumn{6}{|l|}{$\begin{array}{l}\text { Operational Best Practices } \\
\text { and Training for High } \\
\text { Performance } \\
\text { Audience: Operators }\end{array}$} \\
\hline \multicolumn{6}{|c|}{$\begin{array}{l}\text { Performance Assurance } \\
\text { Education for Occupants of } \\
\text { High-Performance Buildings } \\
\text { Audience: Operators }\end{array}$} \\
\hline \multicolumn{6}{|l|}{$\begin{array}{l}\text { Predictive Modeling } \\
\text { Audience: Operators, Utilities }\end{array}$} \\
\hline $\begin{array}{l}\text { Guidelines for Ongoing } \\
\text { Commissioning } \\
\text { Audience: Operators }\end{array}$ & & & & & \\
\hline
\end{tabular}

Figure 5-16 Linking critical operational needs to audience and impact 


\subsubsection{Strategic Approach}

The approach for addressing these needs could focus on understanding the causes of operating failures, developing best practices and tools for avoiding them, designing buildings that can be controlled and operated according to design intent, communicating operational best practices to industry and occupants, and educating all project team members about the consequences of improper commissioning and operational practices, including negative financial impacts, comfort complaints, and installer callbacks. Possible approaches include the following:

- Evaluate the primary causes of operational failures. A good start might be to evaluate the nature and magnitude of design, construction, commissioning, and operating failures that cause buildings to perform below expectations. Several studies, including the one conducted by Mills (2009), provide a strong foundation for determining the frequency and impact of common installation and operating errors. Experts from the commissioning and operations community can be consulted for their expertise about why these failures occur, and how best to address them.

- Establish best practices for commissioning and operating high performance buildings. In consultation with industry experts, benefits could be quantified and best practices could be defined for commissioning, operating, and maintaining key subsystems that are frequently found in high performance buildings, but often fail to achieve the intended savings. These subsystems often interact with other building systems in complex and unexpected ways. Examples of these high priority systems follow:

○ Daylighting systems

- Demand-controlled ventilation

- Heat recovery systems

○ Plug loads

- Enthalpy-based economizers

- Variable air volume systems

- Under floor air distribution

○ Staged heating and cooling

- Dynamic shading systems

○ Integrated system performance.

In the long term, operational challenges may become even more pronounced as buildings approach NZER, because of more complex systems interactions and control strategies. It will be important for best practices to be designed to improve operational performance at a reasonable cost to the building owner.

- Develop new diagnostic technologies and robust design methods, including the role of integrated project delivery in operational performance. "Smart" technologies could be developed to dramatically improve the ease with which systems can be commissioned, making it faster, easier, and cheaper to set and achieve lofty building performance goals. Manufacturers could be supported in the development of advanced self-diagnostic features that alert operators when equipment performance falls below 
acceptable bounds. At the whole-building level, improvements in predictive modeling and building-level fault detection could help operators identify problems early and take corrective action (see Section 5.5).

The impacts of poor commissioning and operational practices can be mitigated through robust design. Design strategies could be developed that require minimal facility manager or occupant intervention, and that are less dependent on complex commissioning strategies. Examples include passive solar design, equipment with simpler interfaces, and more comprehensive building automation. In the right situation, this approach can be more cost-effective than a long term ongoing commissioning program to prevent or address problems.

- Educate owners, industry, and occupants. Partnerships with organizations such as BOMA, the International Facility Managers Association, and others can create stronger training programs to help commissioning agents and facility managers understand how systems interact and the best approaches to ensure they operate in concert to optimize whole-building performance. Training curricula could also be developed for designers and engineers to understand how facility managers approach and operate buildings, which can lead to equipment choices and control strategies that are more intuitive and user friendly.

For building owners, powerful evidence of the financial consequences of incorrect O\&M could be documented. Data related to typical O\&M costs and energy costs could support this activity to enhance credibility (see Section 5.7). Mills (2009) provides comprehensive data in support of careful commissioning and O\&M practices, and Lee et al. (2013) present a convincing case study about the New York Times Building. Templates, best practices, and training curricula for owners and project managers could be developed for inclusion of effective commissioning requirements and strict energy performance requirements in contracts with construction companies to ensure all systems function as intended when the building is handed off (Pless et al. 2011).

Innovative methods can be developed to recognize and reward facility managers who maximize energy savings through effective operational strategies and maintenance practices, including a possible national award program for especially creative and impactful approaches to operations management. Model incentive programs can be created to help owners establish criteria for evaluating and rewarding effective commissioning and facility management practices.

Outreach efforts including social media, websites, fact sheets, and videos could be developed for different building types to educate building occupants about the features of high performance buildings and to communicate simple things they can do to help such buildings perform optimally. Guidance could cover using task lighting, controlling plug loads, consolidating office equipment, adjusting computer standby settings, and other strategies.

- Develop simpler and more innovative approaches for small buildings. Smaller buildings present unique challenges, because the energy cost savings may not be sufficient to justify large expenditures on commissioning and M\&V. Simpler protocols can be developed that support problem identification through utility bill tracking and analysis, along with guidance for correcting minor operational issues without calling a 
service contractor. Benchmarking could be a key element of this approach, because small buildings are less likely to have energy models that establish specific performance expectations for the building (see Section 5.4). DOE is already developing tools such as the Open Energy Information System to assist efforts in this area. Many additional efforts to support commissioning and operational strategies in small buildings may be conducted as part of DOE's new Small Buildings/Small Portfolio program. These efforts could be highly collaborative, involving small building owners, service providers, manufacturers, and utilities.

Solutions may be pursued in all four classifications (Table 5-9).

\section{Table 5-9 Classification of Possible Solutions to Commissioning and Operational Challenges}

\begin{tabular}{|l|l|}
\hline \multicolumn{1}{|c|}{ Classification } & \multicolumn{1}{c|}{ Proposed Solutions } \\
\hline Inspirational & $\begin{array}{l}\text { - Launch an awareness campaign that alerts owners to the financial } \\
\text { impacts of suboptimal commissioning, operation, occupant behavior, } \\
\text { and that identifies potential solutions }\end{array}$ \\
\hline Motivational & $\begin{array}{l}\text { - Encourage owners to adopt incentive programs for facility managers } \\
\text { that reduce energy use through operational improvements } \\
\text { - Initiate a national recognition program with other stakeholder } \\
\text { organizations for building operators and designers that find } \\
\text { innovative ways to maximize the performance of their buildings }\end{array}$ \\
\hline - Define best practices for commissioning, operating, and maintaining \\
subsystems that are essential to achieving NZER \\
- Develop a training curriculum designed to help building operators and \\
engineers maximize the performance of buildings, including training \\
on how building energy models can be used in operations \\
- Recommend more robust design practices that lead to more positive \\
occupant interaction \\
- Improve predictive modeling and building-level fault detection \\
methods
\end{tabular}

\subsubsection{Role of Existing DOE Programs}

DOE has several programs that can be leveraged and expanded to support the possible solutions described in the preceding section:

Innovative $\mathrm{M} \& \mathrm{~V}$ practices are central to DOE research efforts that involve monitoring and characterizing energy use in high performance buildings. Lessons learned from these real-world projects can provide essential insights into potential operational challenges and best practices for overcoming them. 
GSEP provides an excellent forum for establishing best practices, training curricula, and workforce qualifications for continuous energy management and verification. In addition, DOE's ongoing performance-based procurement and performance monitoring initiatives provide strong guidance for ensuring that energy performance goals are supported and tracked throughout the construction process and after the building is occupied.

The Residential Building Integration program has created a series of best practice documents for contractors, designed to improve the installed quality of energy efficiency measures. This guidance could be leveraged for many commercial building types, especially small commercial buildings with HVAC systems that are more representative of residential buildings than of large commercial buildings.

WIP issues grants to state energy offices and other government entities to implement innovative local programs that save energy. Certain minimum requirements are imposed on grantees to ensure that the money is well spent; these can include M\&V of energy savings for all funded projects. Innovative approaches from grant recipients could help inform guidance and best practices developed by DOE to ensure that buildings perform as expected.

\subsubsection{Potential Collaborators}

Several key collaborators would be needed to help develop and implement improved operational strategies in high performance buildings (see Table 5-10).

Table 5-10 Potential Key Collaborators for Commissioning and Operational Solutions

\begin{tabular}{|c|c|c|}
\hline $\begin{array}{l}\text { Collaboration } \\
\text { Category }\end{array}$ & Collaborator Role & Key Collaborators \\
\hline \multirow[t]{3}{*}{ Education } & $\begin{array}{l}\text { Develop best practices for commissioning/ } \\
\text { operations }\end{array}$ & $\begin{array}{l}\text { BOMA, IFMA, PECI, Building Commissioning } \\
\text { Association (BCA), air-conditioning, Heating, } \\
\text { and Refrigeration Institute (AHRI), California } \\
\text { Commissioning Collaborative (CCC), regional } \\
\text { energy collaboratives }\end{array}$ \\
\hline & Develop best practices for $M \& V$ & $\begin{array}{l}\text { Energy Valuation Organization (EVO), BCA, } \\
\text { CCC, energy service companies, engineers, } \\
\text { commissioning agents }\end{array}$ \\
\hline & $\begin{array}{l}\text { Develop curriculum and conduct training for } \\
\text { high performance building operation }\end{array}$ & $\begin{array}{l}\text { Building Operator Certification (Northwest } \\
\text { Energy Efficiency Council), International Union } \\
\text { of Operating Engineers, AHRI, universities, } \\
\text { ASHRAE, Facilities Management Institute, } \\
\text { regional energy collaboratives }\end{array}$ \\
\hline Standardization & $\begin{array}{l}\text { Improve standardization of test methods, } \\
\text { communication protocols, and building } \\
\text { automation systems operational sequences }\end{array}$ & ANSI \\
\hline \multirow[t]{2}{*}{ Diagnostics } & Enhance equipment self-diagnostic capabilities & Manufacturers \\
\hline & Improve sensors and controls & Manufacturers \\
\hline Tool development & $\begin{array}{l}\text { Improve ongoing monitoring and diagnostic } \\
\text { tools }\end{array}$ & $\begin{array}{l}\text { BetterBricks (NEEA), energy dashboard tool } \\
\text { developers, BAS manufacturers, fault detection } \\
\text { and diagnostic developers }\end{array}$ \\
\hline \multirow[t]{2}{*}{ Deployment } & Pilot projects at neighborhood scale & Ecodistricts \\
\hline & $\begin{array}{l}\text { Improve } O \& M \text { and } M \& V \text { requirements in green } \\
\text { building certification programs }\end{array}$ & ASHRAE, USGBC \\
\hline
\end{tabular}




\subsubsection{Solution Timeline}

Figure 5-17 presents a possible commissioning and operational strategies solution timeline, which characterizes solutions as short term ( $0-3$ years), medium term (3-6 years), or long term (6-15 years), and identifies relationships between solutions.

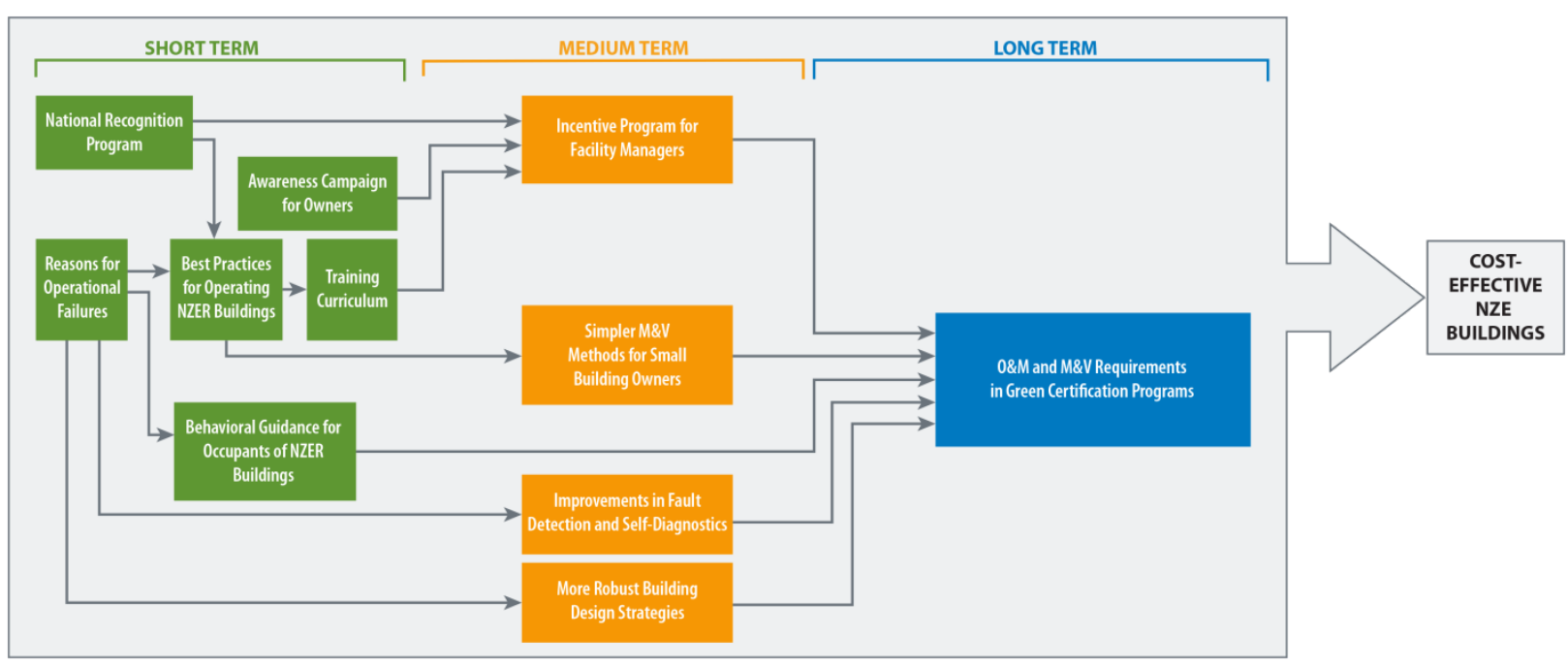

Figure 5-17 Possible commissioning and operational strategy solution timeline

\subsection{Focus Area \#5: Integrated Resources}

Integrated resources that present new construction guides, datasets, and tools in an accessible, adaptable, and user-friendly format enable users to more effectively leverage and deploy all available resources. It is important for such resources to be adaptable to variations in user groups, building types, building designs, and the needs associated with various phases of design and construction.

\subsubsection{Critical Needs}

The commercial buildings industry stakeholders consulted for this project recognize that the buildings research community generates an abundance of valuable resources, but they expressed a need for those resources to be:

- Accessible. At a basic level, resources would be well organized and accessible from a centrally organized online gateway. This criterion simply addresses the question, "Where do I go to find the resources that will be of value to me, and in a media format that aligns with my workflows?"

- Adaptable. Many new resources are produced each year; the resource gateway would likely need continuous maintenance to stay current and track the most valuable resources by focus area and audience.

- User friendly. Effective resource integration can enable potential users to readily determine which resources are most appropriate for their specific interests and needs. The volume and variety of available resources present the need for resource filtering, by a 
set of variables including topic and audience. Stakeholders have expressed the need for brief, high level, intuitive resource descriptions and user-friendly resource formats. For example, a user may be able to internalize more information from watching a 10-minute summary video than from reading a 100-page technical report.

- Integrated. Resource organization and presentation are important needs, but consolidating and condensing them through targeted integration is also important. Such integration must account for the fact that media formats and methods of user engagement are changing. Extracting relevant information and guidance from multiple independent resources is much more difficult than from a single resource that integrates multiple resources in a cohesive, audience-appropriate way.

Figure 5-18 links each need with its core audience and identifies the design and construction stages that might benefit most if it is successfully addressed.

\begin{tabular}{|c|c|c|c|c|c|}
\hline & $\begin{array}{l}\text { Decision } \\
\text { To Act }\end{array}$ & Design & Construction & Operation & Replication \\
\hline $\begin{array}{l}\text { High-Level, User-Friendly } \\
\text { Presentation of Resources } \\
\text { Audience: Owners, States and } \\
\text { Municipalities }\end{array}$ & & & & & \\
\hline $\begin{array}{l}\text { Resource Gateway That } \\
\text { Is Regularly Updated and } \\
\text { Filterable by Audience } \\
\text { Audience: Entire Commercial } \\
\text { Buildings Sector }\end{array}$ & & & & & \\
\hline $\begin{array}{l}\text { Cohesive, Audience- } \\
\text { Appropriate Consolidation } \\
\text { of Resources } \\
\text { Audience: Entire Commercial } \\
\text { Buildings Sector }\end{array}$ & & & & & \\
\hline
\end{tabular}

Figure 5-18 Linking critical integrated resource needs to audience and impact

\subsubsection{Strategic Approach}

A two-pronged approach is recommended for improving the delivery of integrated resources:

- Near-term approach: Integrated resource access. In the near term, resource access could be centralized via a research gateway that is designed to help commercial building audiences (owners/developers, AECOs, building occupants, etc.) more easily identify and locate resources that are most appropriate to their interests and needs. Users would be able to filter resources by intended audience, building type, and various other project parameters (climate, location, performance goal, building system design, budget, etc.). The gateway could be tracked continuously to improve and update resources and remove obsolete ones. Social media may be explored as a venue for users to access information, share successes and challenges with peers, and obtain advice from peers and industry experts. The data storage and access issues are not trivial; successful execution of this approach might require that topics such as modern search and industrial design be 
explored. Many private design firms are currently tackling these issues; accordingly, collaboration in the area of data management would be beneficial.

- Long-term approach: Integrated resource development and gateway expansion. In the long term, complementary resources could be better integrated. This would reduce the need for users to extract bits and pieces from a number of disparate resources that may have been designed to address different audiences and their corresponding needs. A single resource that integrates multiple resources in a cohesive, audience-appropriate way is preferable to a set of independent resources; however, there may be significant barriers to the development of such resources. A first step to comprehensive resource integration might be to examine the resources being developed across DOE's research portfolio in the context of information sharing and overall program integration. As new integrated resources are developed, the ability of case studies to engage owners, developers, and the AECO community can be leveraged.

A case study that demonstrates the successful implementation of a high performance design package in a recognizable commercial building (not a showcase building) for a typical budget can have significant inspirational value. Using supporting data and analysis to generalize the results, and making the case study more interactive and "alive," can motivate decision makers and designers and provide relevant design guidance and solutions for a broader range of buildings. Overall resource impact might be improved via this approach. As new integrated resources are developed, they can be incorporated into the resource gateway.

Near-term gateway design and development, and initial deployment using DOE resources could largely set the stage for this effort. Because the inclusion of non-DOE resources has the potential to greatly increase the ongoing effort required for update and maintenance, it would be valuable to establish workflows and partnership agreements that lay the groundwork for successful, sustainable expansion of the gateway.

Solutions may be pursued in all four classifications (Table 5-11). 
Table 5-11 Classification of Possible Solutions to Integrated Resource Challenges

\begin{tabular}{|l|l|}
\hline \multicolumn{1}{|c|}{ Classification } & \multicolumn{1}{|c|}{ Proposed Solutions } \\
\hline Inspirational & $\begin{array}{l}\text { - Leverage the inspirational value of case studies to engage } \\
\text { targeted audiences; and condense guidance down to a level that is } \\
\text { appropriate for influencing the decision to act and early design }\end{array}$ \\
\hline Motivational & $\begin{array}{l}\text { - Produce interactive case studies that emphasize cost and } \\
\text { performance details, use analysis to expand the applicability of } \\
\text { the relevant design and construction strategies to a wider range of } \\
\text { project parameters, and link to additional resources of interest }\end{array}$ \\
\hline Procedural & $\begin{array}{l}\text { - Specify a workflow that allows existing resources to be filtered } \\
\text { according to project parameters and intended audience } \\
\text { - Specify a resource taxonomy, that addresses the need to sort by both } \\
\text { topic and audience } \\
\text { - Define the requirements of a centralized gateway for resources that } \\
\text { would enable users to find the information they need in one place, and } \\
\text { engage with experts and peers through social media } \\
\text { - Define workflows and responsibilities that will allow expansion of the } \\
\text { resource gateway to include significant non-DOE resources }\end{array}$ \\
\hline $\begin{array}{l}\text { - Develop a market-facing centralized gateway for resources that will } \\
\text { streamline the process through which DOE research achieves its } \\
\text { intended market impact }\end{array}$ \\
\hline Practical
\end{tabular}

\subsubsection{Role of Existing DOE Programs}

DOE has several programs that could be leveraged and expanded to support the possible solutions described in the preceding section:

DOE programs with database development focus can inform the development of a centralized, user-friendly online resource gateway. Examples include the High Performance Buildings Database, the Life Cycle Inventory Database, the SEED Platform, and the Technology Portal. These programs can guide the specification of the resource taxonomy, and address the need for resource filtration.

Numerous DOE programs, including the Technology Demonstration program, CBP, the BBA, the Better Buildings Challenge, and the High Performance Buildings Database, use case studies as the primary mechanism for communicating results. As efforts proceed to make case studies central to new integrated resources, lessons learned from these projects may prove valuable.

The AEDGs, which focus on audience-specific packaging of design and construction expertise, energy modeling results, and whole-building and system-level case studies, can be useful references for the development of new integrated resources. Additionally, CBP efforts are shifting from producing case studies to developing integrated resources that are designed to expand the applicability of those case studies to a wider audience.

\subsubsection{Potential Collaborators}

Numerous collaborators may be necessary for the successful development and deployment of integrated resources. Some of the most important collaborations are described in Table 5-12. 
Table 5-12 Potential Key Collaborators for Integrated Resource Solutions

\begin{tabular}{|c|c|c|}
\hline $\begin{array}{l}\text { Collaboration } \\
\text { Category }\end{array}$ & Collaborator Role & Key Collaborators \\
\hline \multirow[t]{3}{*}{ Content } & Create interactive AEDGs & ASHRAE \\
\hline & Online tools and guidance & $\begin{array}{l}\text { NBI, Rocky Mountain Institute (RMI), NEEA, EPA, } \\
\text { National Fenestration Rating Council, COMNET, } \\
\text { Lighting Research Center, California Lighting } \\
\text { Technology Center }\end{array}$ \\
\hline & Create detailed and interactive case studies & $\mathrm{NBI}, \mathrm{RMI}$ \\
\hline Platforms & Facilitate resource integration and packaging & $\begin{array}{l}\text { NBI, RMI, AIA, USGBC, Northeast Energy } \\
\text { Efficiency Partnerships (NEEP), EPA, Living } \\
\text { Building Challenge, Center for the Built } \\
\text { Environment, data integrators, social media }\end{array}$ \\
\hline \multirow[t]{2}{*}{ Deployment } & $\begin{array}{l}\text { Provide training in the use of integrated } \\
\text { resources }\end{array}$ & AIA, USGBC \\
\hline & $\begin{array}{l}\text { Identify significant non-DOE resources to be } \\
\text { included in the resource gateway }\end{array}$ & $\mathrm{NBI}, \mathrm{RMI}, \mathrm{EPA}, \mathrm{ACEEE}$ \\
\hline
\end{tabular}

Other potential collaborators for integrated resource solutions include:

- Design-Build Institute of America

- AHRI

- Universities

- Labs21

- Utilities

- International Living Future Institute (ILFI).

\subsubsection{Solution Timeline}

Figure 5-19 presents a possible integrated resource solution timeline, which characterizes solutions as short term (0-3 years), medium term (3-6 years), or long term (6-15 years), and identifies relationships between solutions.

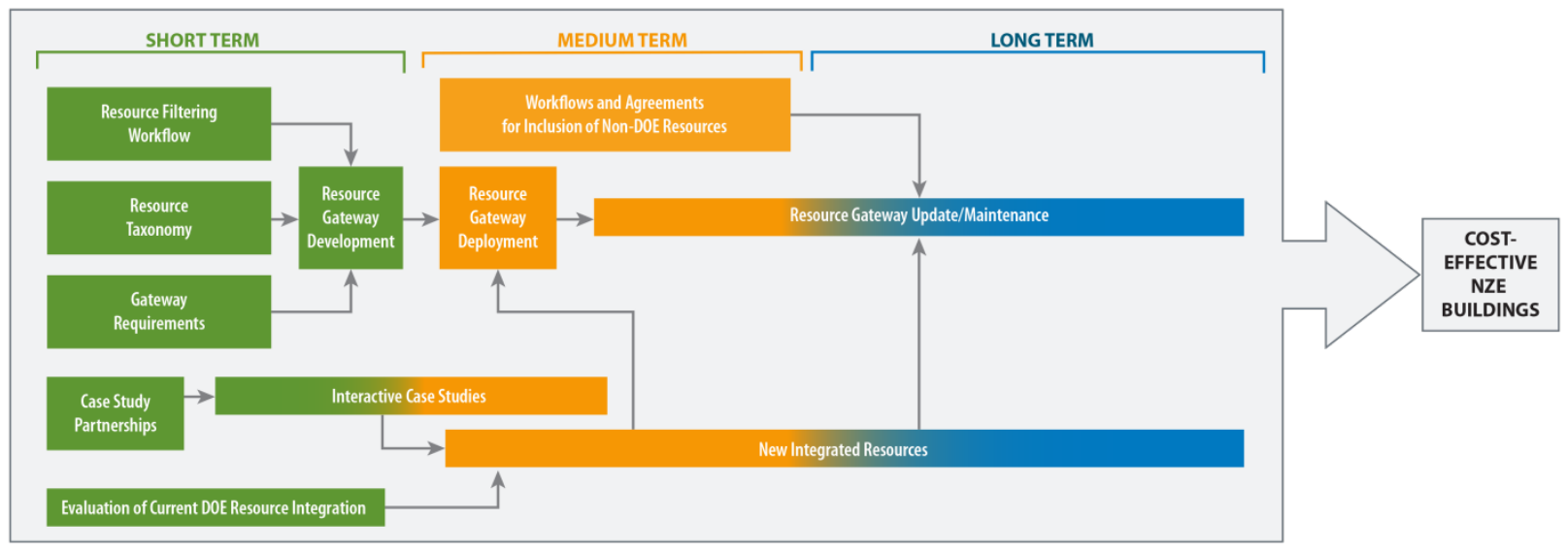

Figure 5-19 Possible integrated resource solution timeline 


\subsection{Renewable Energy and Grid Interactions}

There are important interconnections between the energy efficiency component of NZE (the focus of this report), renewable energy generation, and the electrical grid. The load variability of NZE buildings and the associated risk to supply-side optimization may represent a significant obstacle to achieving the market penetration of NZE suggested by the Architecture 2030 initiative and EISA 2007. Commercially viable NZE buildings are expected to become a larger share of the commercial building footprint as government and private sector polices continue to push for buildings to produce more on-site energy than they use. However, the load profiles of NZE buildings are perceived by electric utilities to be unfavorable and unpredictable.

To reach net zero in large commercial buildings, significant on-site renewables typically export to the electric utility to offset energy use during night hours. Currently, most NZE buildings do not manage the resulting load shapes. This can result in a utility load profile that can wildly fluctuate from exporting to importing, have minimal peak demand savings, and still peak during summer afternoons. Potential electric vehicle charging has the potential to make the load profile even less favorable. Improved methods for controlling NZE load profiles could be developed to manage the numerous building scale, storage, and demand response options available, optimizing utility grid interactions while increasing the value to the building owner. 


\section{Conclusions}

For decades, DOE has developed and deployed resources, methods, tools, and technologies that improve energy efficiency in commercial buildings. Thanks in large part to these efforts, high performance buildings are becoming much more common, and it is even possible in some situations to design and construct cost-effective NZE buildings that produce as much energy as they consume. Although many essential high performance building principles are well understood, uptake in the marketplace for new commercial construction is limited by real and perceived barriers, technical roadblocks, and financial constraints.

This report identifies possible goals and strategic priorities for DOE's portfolio of new construction research and deployment programs, focusing on the CBI program. These recommendations were built around the foundation of five key focus areas that reflect the results of an intensive gap analysis and stakeholder dialogues. These focus areas, along with several possible high priority activities, are described below:

1. Energy benchmark data: System and whole-building level energy benchmark data, organized by building type and climate, which can be used for setting performance targets for new buildings.

- Define normalization methods and metrics that address building use, size, and other energy drivers.

- Create analysis-based whole building benchmarks by climate zone and building type, normalized as appropriate.

- Establish analysis-based whole building targets for high performance and NZER buildings.

- Define end-use level targets consistent with whole-building targets.

- Leverage Portfolio Manager and the Building Performance Database to gather a statistically significant set of high performance new construction benchmark data.

2. Enhanced modeling tools: Improved modeling tools to support financial decisionmaking, whole-building design, analysis of new technologies, model calibration, and identification of operational/behavioral influences on energy use throughout the building life cycle.

- Provide efficiency package optimization capability.

- Develop better early stage design tools, such as using heuristic-based analysis derived from large-scale simulations of efficiency perturbations individually and in combination. .

- Develop prepackaged optimized design solutions for small businesses.

- Conduct a study of user interface needs for diverse audiences and applications, and customize user interfaces for those audiences.

- Perform laboratory and field testing of high performance building equipment and complex systems to improve modeling algorithm accuracy. 
3. Better cost data: Objective, vetted average component- and system-level cost data for analysis of return on investment.

- Perform an assessment of industry cost data workflows.

- Identify cost data parameters that impact design decisions.

- Establish a cost estimation procedure that systematically accounts for system interactions and tradeoffs.

- Develop a clear business case for community-based cost data collection to motivate building owners, AECO companies, equipment manufacturers, and equipment vendors to supply cost information to a public database.

- Expand partnerships for cost data collection and maintenance.

- Create a publicly accessible cost database that facilitates early design decision making, or support enhancements to existing databases to include cost data.

4. Commissioning and operational strategies: Effective commissioning and operational methods, technologies, and tools, demonstrated through case studies.

- Improve project delivery methods to better ensure that high performance buildings meet specified targets.

- Study the nature and magnitude of commissioning and operating failures that cause buildings to perform below expectations.

- Document best practices for commissioning, operating, and maintaining advanced systems and technologies in high performance buildings.

- Develop educational materials for building occupants about the features of high performance buildings and simple things they can do to help such buildings perform optimally.

- Identify robust design strategies, self-diagnostic capabilities, and automated fault detection techniques that mitigate the impact of operational deficiencies.

5. Integrated resources: Integrated resources that include new construction case studies, best practice guides, datasets, and tools in a more accessible, adaptable, and user-friendly format.

- Evaluate current federal resource integration practices to determine opportunities for improved delivery of information.

- Create a workflow specification and resource taxonomy that allows all available resources to be filtered according to project parameters and intended audience.

- Establish the requirements of a centralized gateway for resources that would enable users to find the information they need in one place.

- Document case studies that emphasize cost and performance details, and use additional analysis to expand the applicability of the relevant design and construction strategies to a wider range of project parameters. 
While the recommendations in this report address each of the five key focus areas individually, a holistic, integrated approach to project definition, execution, and evaluation could maximize the ability of new construction efforts to address the critical barriers that inhibit large scale uptake of high performance buildings in the commercial sector. Moving forward, coordination between focus areas will be valuable for ensuring that such interdependencies are properly addressed. A coordinated effort in which the work in one focus area builds from and supports the work in the others could increase both the value of DOE's investment and the ability of these efforts to transform the commercial buildings sector.

The recommended solutions described in this report could lead to improved technologies, more user-friendly integrated building systems, sustainable business models, and greatly enhanced deployment of high performance commercial buildings. Broad implementation of high performance and NZE buildings will require the ongoing participation and advice of commercial building professionals on the front lines. Collaborations between DOE experts and industry will be essential for stimulating innovation and leading the market toward the ultimate goal of costeffective NZE commercial buildings by 2030. 


\section{References}

Baker, K. 2012. Despite National and International Impediments, Some Improvement Anticipated: Weak economic growth is holding back a construction recovery. Practicing Architecture. American Institute of Architects. www.aia.org/practicing/AIAB095480

Briggs, R.S., R.G. Lucas, and Z.T. Taylor. 2003. Climate classification for building energy codes and standards: Part 2-Zone Definitions, Maps, and Comparisons. ASHRAE Transactions 109(1):122-130.

Building Design+Construction. 2011. Zero and Net-Zero Energy Buildings + Homes: Eighth in a Series of White Papers on the Green Building Movement. www.bdcnetwork.com/2011-zeroand-net-zero-energy-buildings-homes

DOE. 2001. High-Performance Commercial Buildings: A Technology Roadmap. Office of Building Technology, State and Community Programs. Report DOE/GO-1020011343. www.nrel.gov/docs/fy01osti/30171.pdf

DOE. 2003. Commercial Buildings Energy Consumption Survey (CBECS). Washington, DC: U.S. Department of Energy. www.eia.gov/emeu/cbecs/

DOE. Undated, circa 2008. Building Technologies Program Planning Summary. www1.eere.energy.gov/buildings/pdfs/btp_planning.pdf

DOE. 2008. Building Technologies Program Planned Program Activities for 20082012. http://apps1.eere.energy.gov/buildings/publications/pdfs/corporate/myp08complete.pdf

DOE. 2011. Building Technologies Program: Multi-Year Work Plan 20112015. http://apps1.eere.energy.gov/buildings/publications/pdfs/corporate/myp11.pdf

DOE. 2012a. Annual Energy Outlook. Reference Case Tables Released: December 5, 2012. www.eia.gov/analysis/projection-data.cfm

DOE. 2012b. 2011 Buildings Energy Data Book. Prepared by D\&R International, Ltd. under contract to Pacific Northwest National Laboratory. http://buildingsdatabook.eren.doe.gov/default.aspx

DOE. 2013. Advanced Energy Retrofit Guide for K-12 Schools. DOE/GO-1020133467. wwwl.eere.energy.gov/buildings/commercial/aerg.html

Energetics Incorporated. Summary Report: Policy Options Workshop: Accelerating Energy Efficiency in Commercial Buildings. 2011. Report to the U.S. Department of Energy, Office of Policy and International Affairs, and Oak Ridge National Laboratory. www.energetics.com/resourcecenter/products/studies/Documents/Commercial_Buil ding_Policy_Workshop.pdf 
Energy Design Resources. 2012. Zero Net Energy: The zero net energy future starts today. ENEWS, Issue 86, October

2012. www.energydesignresources.com/media/12336528/edr_enews 086.pdf

Engage360/CPUC. 2010. California Energy Efficiency Strategic Plan, Net Zero Energy Action Plan. www.cpuc.ca.gov/NR/rdonlyres/6C2310FE-AFE0-48E4-AF03-

530A99D28FCE/0/ZNEActionPlanFINAL83110.pdf

Griffith, B., Long, N., Torcellini, P., and Judkoff, R. 2007. National Renewable Energy

Laboratory; D. Crawley and J. Ryan, U.S. Department of Energy. Assessment of the Technical

Lee, E.S., Fernandes, L.L., Coffey, B., McNeil, A., Clear, R., Webster, T., Bauman, F., Dickerhoff, D., Heinzerling, D., and Hoyt, T. 2013. A Post-Occupancy Monitored Evaluation of the Dimmable Lighting, Automated Shading, and Underfloor Air Distribution System in the New York Times Building. LBNL Report: LBNL6023E. http://buildings.lbl.gov/sites/all/files/lbnl-6023e.pdf

Potential for Achieving Net Zero-Energy Buildings in the Commercial Sector. Technical Report NREL/TP-550-41957. www.nrel.gov/docs/fy080sti/41957.pdf

Heschong Mahone Group, Inc. 2012. The Road to ZNE: Mapping Pathways to ZNE Buildings in California (Draft). Report to Pacific Gas and Electric

Company. www.energydataweb.com/cpucFiles/pdaDocs/891/Road $\% 20$ to $\% 20 Z N E \% 20 D r a f t \% 2$ 0Report_PUBLICDRAFT_121120.pdf

Massachusetts Zero Net Energy Buildings Task Force. 2009. Getting to Zero: Final Report of the Massachusetts Zero Net Energy Buildings Task

Force. www.mass.gov/eea/docs/eea/press/publications/zneb-taskforce-report.pdf

McGraw Hill Construction. 2012b. WORLD GREEN BUILDING TRENDS: Business Benefits Driving New and Retrofit Market Opportunities In Over 60

Countries. www.worldgbc.org/files/8613/6295/6420/World_Green_Building_Trends_SmartMar ket Report 2013.pdf

McGraw Hill Construction. 2012a. 2013 Dodge Construction Outlook.

Mills, E. 2009. Building Commissioning: A Golden Opportunity for Reducing Energy Costs and Greenhouse Gas Emissions. Report to California Energy Commission. Berkeley, CA:

Lawrence Berkeley National Laboratory. http://cx.lbl.gov/documents/2009-assessment/lbnl-cxcost-benefit.pdf

National Science and Technology Council Committee on Technology. 2008. "Federal Research and Development Agenda for Net-Zero Energy, High-Performance Green Buildings." Report of the Subcommittee on Buildings Technology Research and Development, October 2008. www.bfrl.nist.gov/buildingtechnology/documents/FederalRDAgendaforNetZeroEnergyHi ghPerformanceGreenBuildings.pdf 
NBI. 2012. Getting to Zero 2012 Status Update: A First Look at the Costs and Features of Zero Energy Commercial Buildings. Research Report. Vancouver, WA: New Buildings Institute. www.newbuildings.org/sites/default/files/GettingtoZeroReport_0.pdf

NBI; NASEO. 2012. Developing a National Zero-Net Energy Action Plan: San Francisco Meeting Report. Vancouver, WA: New Buildings Institute and Arlington, VA: National Association of State Energy Officials. http://newbuildings.org/sites/default/files/ZNE_Meeting_Report_7-24_0.pdf

Northeast Energy Efficiency Partnerships. 2012. Roadmap to Zero Net Energy Public Buildings: Recommended Steps for the Northeast and MidAtlantic. http://neep.org/uploads/policy/zne-public-buildings-neep-2012.pdf

Pacific Gas \& Electric Company. 2012. The Technical Feasibility of Zero Net Energy Buildings in California. DRAFT Report

ZNE/219664. www.energydataweb.com/cpucFiles/pdaDocs/890/ZNE\%20Technical\%20Feasibi lity\%20-\%20DRAFT\%20Report.pdf

Pless, S.; Torcellini, P. 2010. Net-Zero Energy Buildings: A Classification System Based on Renewable Energy Supply Options. 21 pp.; NREL Report No. TP-550-

44586. http://www.nrel.gov/sustainable nrel/pdfs/44586.pdf

Pless, S.; Torcellini, P.; Shelton, D. 2011. Using an Energy Performance Based Design-Build Process to Procure a Large Scale Low-Energy Building. ASHRAE Winter Conference, Las Vegas, Nevada, January 29 - February 2, 2011. Conference Paper NREL/CP-550051323. www.nrel.gov/sustainable nrel/pdfs/51323.pdf

Selkowitz, S.; Granderson, J.; Haves, P.; Mathew, P.; Harris, J. 2008. Scale Matters: An Action Plan for Realizing Sector-Wide "Zero Energy" Performance Goals in Commercial Buildings. Berkeley, CA: Lawrence Berkeley National Laboratory and Washington, D.C.: Alliance to Save Energy. http://escholarship.org/uc/item/1kf4t1nh\#page-1

Torcellini, P.; Pless, S.; Deru, M.; Crawley, D. 2006. Zero Energy Buildings: A Critical Look at the Definition (Preprint). Golden, CO: National Renewable Energy Laboratory. CP-55039833. www.nrel.gov/docs/fy06osti/39883.pdf

World Business Council for Sustainable Development. 2009. Transforming the Market: Energy Efficiency in Buildings. www.wbcsd.org/transformingthemarketeeb.asp $\mathrm{x}$

Zero Energy Commercial Buildings Consortium. 2011. Next Generation Technologies Barriers \& Industry Recommendations for Commercial Building. http://zeroenergycbc.org/wpcontent/uploads/2011/07/CBC-Technologies-Report-2011.pdf 


\section{Appendix A: Roadmaps, Policy Studies, and Market Analyses Used To Guide Recommendations}

Table A-1 Publications Used To Guide the Recommendations in This Report

\begin{tabular}{|c|c|c|}
\hline Number & Document & Type \\
\hline 1 & $\begin{array}{l}\text { Baker, K. 2012. Despite National and International Impediments, Some } \\
\text { Improvement Anticipated: Weak economic growth is holding back a } \\
\text { construction recovery. Practicing Architecture. American Institute of } \\
\text { Architects. www.aia.org/practicing/AIAB095480 }\end{array}$ & $\begin{array}{c}\text { Market } \\
\text { Analysis }\end{array}$ \\
\hline 2 & $\begin{array}{l}\text { Building Design+Construction. 2011. Zero and Net-Zero Energy } \\
\text { Buildings + Homes: Eighth in a Series of White Papers on the Green } \\
\text { Building Movement./www.bdcnetwork.com/2011-zero-and-net-zero- } \\
\text { energy-buildings-homes }\end{array}$ & White Paper \\
\hline 3 & $\begin{array}{l}\text { Energetics Incorporated. Summary Report: Policy Options Workshop: } \\
\text { Accelerating Energy Efficiency in Commercial Buildings. 2011. Report to } \\
\text { the U.S. Department of Energy, Office of Policy and International Affairs, } \\
\text { and Oak Ridge National Laboratory. } \\
\text { www.energetics.com/resourcecenter/products/studies/Documents/Comm } \\
\text { ercial_Building_Policy_Workshop.pdf }\end{array}$ & $\begin{array}{l}\text { Workshop } \\
\text { Summary }\end{array}$ \\
\hline 4 & $\begin{array}{l}\text { Energy Design Resources. 2012. Zero Net Energy: The zero net energy } \\
\text { future starts today. E-NEWS, Issue 86, October 2012. } \\
\text { www.energydesignresources.com/media/12336528/edr_enews_086.pdf }\end{array}$ & $\begin{array}{l}\text { Newsletter } \\
\text { Article }\end{array}$ \\
\hline 5 & $\begin{array}{l}\text { Engage360/CPUC. 2010. California Energy Efficiency Strategic Plan, } \\
\text { Net Zero Energy Action Plan. } \\
\text { www.cpuc.ca.gov/NR/rdonlyres/6C2310FE-AFE0-48E4-AF03- } \\
\text { 530A99D28FCE/O/ZNEActionPlanFINAL83110.pdf }\end{array}$ & Roadmap \\
\hline 6 & $\begin{array}{l}\text { Massachusetts Zero Net Energy Buildings Task Force. 2009. Getting to } \\
\text { Zero: Final Report of the Massachusetts Zero Net Energy Buildings Task } \\
\text { Force. www.mass.gov/eea/docs/eea/press/publications/zneb-taskforce- } \\
\text { report.pdf }\end{array}$ & Roadmap \\
\hline 7 & $\begin{array}{l}\text { McGraw Hill Construction. 2012. WORLD GREEN BUILDING TRENDS: } \\
\text { Business Benefits Driving New and Retrofit Market Opportunities In Over } \\
60 \text { Countries. http://analyticsstore.construction.com/index.php/2012- } \\
\text { world-green-building-trends-key-facts.html }\end{array}$ & $\begin{array}{c}\text { Market } \\
\text { Analysis }\end{array}$ \\
\hline 8 & $\begin{array}{l}\text { National Science and Technology Council Committee on Technology. } \\
\text { 2008. "Federal Research and Development Agenda for Net-Zero Energy, } \\
\text { High-Performance Green Buildings." Report of the Subcommittee on } \\
\text { Buildings Technology Research and Development, October } 2008 \text {. } \\
\text { www.bfrl.nist.gov/buildingtechnology/documents/FederalRDAgendaforNet } \\
\text { ZeroEnergyHighPerformanceGreenBuildings.pdf }\end{array}$ & Roadmap \\
\hline 9 & $\begin{array}{l}\text { New Buildings Institute. 2012. Getting to Zero } 2012 \text { Status Update: A } \\
\text { First Look at the Costs and Features of Zero Energy Commercial } \\
\text { Buildings. Research Report. } \\
\text { www.newbuildings.org/sites/default/files/GettingtoZeroReport_0.pdf }\end{array}$ & $\begin{array}{c}\text { Market } \\
\text { Analysis }\end{array}$ \\
\hline 10 & $\begin{array}{l}\text { New Buildings Institute and National Association of State Energy } \\
\text { Officials. 2012. Developing a National Zero-Net Energy Action Plan: } \\
\text { San Francisco Meeting Report. http://newbuildings.org/sites/default/ } \\
\text { files/ZNE_Meeting_Report_7-24_0.pdf }\end{array}$ & $\begin{array}{l}\text { Workshop } \\
\text { Summary }\end{array}$ \\
\hline
\end{tabular}




\begin{tabular}{|c|c|c|}
\hline 11 & $\begin{array}{l}\text { Northeast Energy Efficiency Partnerships. 2012. Roadmap to Zero Net } \\
\text { Energy Public Buildings: Recommended Steps for the Northeast and } \\
\text { Mid-Atlantic. http://neep.org/uploads/policy/zne-public-buildings-neep- } \\
\text { 2012.pdf }\end{array}$ & Roadmap \\
\hline 12 & $\begin{array}{l}\text { Selkowitz, Stephen, Jessica Granderson, Philip Haves, Paul Mathew, } \\
\text { Lawrence Berkeley National Laboratory; Jeff Harris, Alliance to Save } \\
\text { Energy. 2008. Scale Matters: An Action Plan for Realizing Sector-Wide } \\
\text { "Zero Energy" Performance Goals in Commercial Buildings. } \\
\text { http://escholarship.org/uc/item/1kf4t1nh\#page-1 }\end{array}$ & Roadmap \\
\hline 13 & $\begin{array}{l}\text { U.S. DOE. Undated, circa 2008. Building Technologies Program } \\
\text { Planning Summary. } \\
\text { www1.eere.energy.gov/buildings/pdfs/btp_planning.pdf }\end{array}$ & Program Plan \\
\hline 14 & $\begin{array}{l}\text { U.S. DOE. 2011. Building Technologies Program: Multi-Year Work Plan } \\
\text { 2011-2015. http://apps1.eere.energy.gov/buildings/publications/pdfs/ } \\
\text { corporate/myp11.pdf }\end{array}$ & Program Plan \\
\hline 15 & $\begin{array}{l}\text { U.S. DOE. 2008. Building Technologies Program Planned Program } \\
\text { Activities for 2008-2012. http://apps1.eere.energy.gov/buildings/ } \\
\text { publications/pdfs/corporate/myp08complete.pdf }\end{array}$ & Program Plan \\
\hline 16 & $\begin{array}{l}\text { World Business Council for Sustainable Development. } 2009 . \\
\text { Transforming the Market: Energy Efficiency in Buildings. } \\
\text { www.wbcsd.org/transformingthemarketeeb.aspx }\end{array}$ & Roadmap \\
\hline 17 & $\begin{array}{l}\text { Zero Energy Commercial Buildings Consortium. 2011. Next Generation } \\
\text { Technologies Barriers \& Industry Recommendations for Commercial } \\
\text { Building. http://zeroenergycbc.org/wp-content/uploads/2011/07/CBC- } \\
\text { Technologies-Report-2011.pdf }\end{array}$ & Roadmap \\
\hline 18 & $\begin{array}{l}\text { Pacific Gas \& Electric Company. 2012. The Technical Feasibility of Zero } \\
\text { Net Energy Buildings in California. DRAFT Report ZNE/219664. } \\
\text { www.energydataweb.com/cpucFiles/pdaDocs/890/ZNE\%20Technical\%2 } \\
\text { OFeasibility\%20-\%20DRAFT\%20Report.pdf }\end{array}$ & $\begin{array}{c}\text { Technology } \\
\text { Analysis }\end{array}$ \\
\hline 19 & $\begin{array}{l}\text { B. Griffith, N. Long, P. Torcellini, and R. Judkoff, National Renewable } \\
\text { Energy Laboratory; D. Crawley and J. Ryan, U.S. Department of } \\
\text { Energy. 2007. Assessment of the Technical Potential for Achieving Net } \\
\text { Zero-Energy Buildings in the Commercial Sector. Technical Report } \\
\text { NREL/TP-550-41957. www.nrel.gov/docs/fy08osti/41957.pdf }\end{array}$ & $\begin{array}{c}\text { Technology } \\
\text { Analysis }\end{array}$ \\
\hline 20 & $\begin{array}{l}\text { U.S. Department of Energy, Office of Building Technology, State and } \\
\text { Community Programs. 2001. High-Performance Commercial Buildings: } \\
\text { A Technology Roadmap. Report DOE/GO-102001-1343. } \\
\text { www.nrel.gov/docs/fy01osti/30171.pdf }\end{array}$ & Roadmap \\
\hline 21 & $\begin{array}{l}\text { Heschong Mahone Group, Inc. 2012. The Road to ZNE: Mapping } \\
\text { Pathways to ZNE Buildings in California (Draft). Report to Pacific Gas } \\
\text { and Electric Company. } \\
\text { www.energydataweb.com/cpucFiles/pdaDocs/891/Road\%20to\%20ZNE\% } \\
\text { 20Draft\%20Report_PUBLICDRAFT_121120.pdf }\end{array}$ & Roadmap \\
\hline
\end{tabular}




\section{Appendix B: Prioritization of Barriers Identified in Previous Roadmaps}

Table B-1 Identified Barriers

\begin{tabular}{|c|c|c|c|c|}
\hline \# & Category & Barrier & $\begin{array}{l}\text { Within } \\
\text { DOE } \\
\text { Purview? }\end{array}$ & $\begin{array}{l}\text { Number } \\
\text { of } \\
\text { Citations }\end{array}$ \\
\hline 1 & $\begin{array}{l}\text { Financing } \\
\text { Mechanisms }\end{array}$ & $\begin{array}{l}\text { Lack of model tax incentives for energy } \\
\text { efficiency }\end{array}$ & No & 1 \\
\hline 2 & $\begin{array}{l}\text { Financing } \\
\text { Mechanisms }\end{array}$ & $\begin{array}{l}\text { Lack of access to capital for efficiency } \\
\text { improvements, or prohibitively high cost of } \\
\text { capital }\end{array}$ & Yes & 3 \\
\hline 3 & $\begin{array}{l}\text { Financing } \\
\text { Mechanisms }\end{array}$ & $\begin{array}{l}\text { ROI expectations for efficiency investments are } \\
\text { typically higher than for other projects because } \\
\text { they are not perceived as core to company } \\
\text { operations }\end{array}$ & Yes & 1 \\
\hline 4 & $\begin{array}{l}\text { Financing } \\
\text { Mechanisms }\end{array}$ & $\begin{array}{l}\text { Financial analysis models are often over- } \\
\text { generalized and opaque, utilizing only a few } \\
\text { inapplicable inputs or using assumptions and } \\
\text { algorithms that do not correctly evaluate the } \\
\text { projected payback }\end{array}$ & Yes & 1 \\
\hline 5 & $\begin{array}{l}\text { Financing } \\
\text { Mechanisms }\end{array}$ & $\begin{array}{l}\text { Ingrained practices in the financial and real } \\
\text { estate sectors fail to sufficiently recognize the } \\
\text { increase in buildings' values associated with } \\
\text { energy efficiency improvements }\end{array}$ & Yes & 3 \\
\hline 6 & $\begin{array}{l}\text { Financing } \\
\text { Mechanisms }\end{array}$ & $\begin{array}{l}\text { Amortization schedules and other tax incentives } \\
\text { favor turnover of commercial buildings, reducing } \\
\text { incentives to make energy efficiency } \\
\text { investments that have longer payback periods }\end{array}$ & No & 1 \\
\hline 7 & $\begin{array}{l}\text { Financing } \\
\text { Mechanisms }\end{array}$ & $\begin{array}{l}\text { Utilities are incentivized to lower their rates to } \\
\text { attract and retain customers and have much } \\
\text { less incentive to focus on lowering their } \\
\text { customers' energy bills }\end{array}$ & No & 1 \\
\hline 8 & $\begin{array}{l}\text { Financing } \\
\text { Mechanisms }\end{array}$ & $\begin{array}{l}\text { Government entities need greater access to } \\
\text { financial instruments such as federal and state } \\
\text { tax incentives }\end{array}$ & No & 1 \\
\hline 9 & $\begin{array}{l}\text { Financing } \\
\text { Mechanisms }\end{array}$ & $\begin{array}{l}\text { Tax incentives often have a time-consuming } \\
\text { application processes that does not coincide } \\
\text { with the real estate commercial development } \\
\text { cycle }\end{array}$ & No & 1 \\
\hline 10 & $\begin{array}{l}\text { Strategy/Package } \\
\text { Selection }\end{array}$ & $\begin{array}{l}\text { Lack of tools and resources dedicated to } \\
\text { specific sectors (such as schools) }\end{array}$ & Yes & 1 \\
\hline 11 & $\begin{array}{l}\text { Strategy/Package } \\
\text { Selection }\end{array}$ & $\begin{array}{l}\text { Decision-makers need better information about } \\
\text { techniques for achieving substantial energy use } \\
\text { reductions and the estimated costs and benefits } \\
\text { of those measures }\end{array}$ & Yes & 5 \\
\hline 12 & $\begin{array}{l}\text { Strategy/Package } \\
\text { Selection }\end{array}$ & $\begin{array}{l}\text { Information on integrated design is lacking in } \\
\text { high performance building databases }\end{array}$ & Yes & 1 \\
\hline 13 & $\begin{array}{l}\text { Strategy/Package } \\
\text { Selection }\end{array}$ & $\begin{array}{l}\text { Many of the failures in modern buildings are } \\
\text { system integration failures }\end{array}$ & Yes & 1 \\
\hline
\end{tabular}




\begin{tabular}{|c|c|c|c|c|}
\hline 14 & $\begin{array}{l}\text { Strategy/Package } \\
\text { Selection }\end{array}$ & $\begin{array}{l}\text { The technologies and integrated systems } \\
\text { needed for many designs are not easy to find at } \\
\text { affordable cost and are challenging to } \\
\text { incorporate into a design in a manner that will } \\
\text { work reliably }\end{array}$ & Yes & 3 \\
\hline 15 & $\begin{array}{l}\text { Measurement and } \\
\text { Verification }\end{array}$ & $\begin{array}{l}\text { Need for standardized procedures for } \\
\text { measurement, calibration, and publishing of } \\
\text { performance data }\end{array}$ & Yes & 1 \\
\hline 16 & $\begin{array}{l}\text { Measurement and } \\
\text { Verification }\end{array}$ & $\begin{array}{l}\text { Lack of testing approaches for nonenergy } \\
\text { benefits }\end{array}$ & Yes & 1 \\
\hline 17 & $\begin{array}{l}\text { Measurement and } \\
\text { Verification }\end{array}$ & $\begin{array}{l}\text { Most bill-payers lack sufficient access to } \\
\text { detailed utility billing data }\end{array}$ & No & 2 \\
\hline 18 & $\begin{array}{l}\text { Strategy/Package } \\
\text { Selection }\end{array}$ & $\begin{array}{l}\text { Energy prices can fluctuate tremendously, } \\
\text { casting uncertainty on potential savings from } \\
\text { investments in energy efficiency }\end{array}$ & No & 2 \\
\hline 19 & $\begin{array}{l}\text { Strategy/Package } \\
\text { Selection }\end{array}$ & $\begin{array}{l}\text { Owners and lenders are focused on the cost of } \\
\text { construction or short-term returns on investment } \\
\text { while ignoring long-term operating cost savings } \\
\text { due to increased building performance }\end{array}$ & Yes & 7 \\
\hline 20 & $\begin{array}{l}\text { Strategy/Package } \\
\text { Selection }\end{array}$ & $\begin{array}{l}\text { There is a dearth of information on the non- } \\
\text { energy benefits of efficiency packages and } \\
\text { measures }\end{array}$ & Yes & 2 \\
\hline 21 & $\begin{array}{l}\text { Measurement and } \\
\text { Verification }\end{array}$ & $\begin{array}{l}\text { Energy utility bills typically lack the granularity } \\
\text { required to pinpoint the elements driving energy } \\
\text { use in any particular building }\end{array}$ & Yes & 2 \\
\hline 22 & $\begin{array}{l}\text { Portfolio/Multi- } \\
\text { Building Analysis }\end{array}$ & $\begin{array}{l}\text { There is a tendency to look at buildings as } \\
\text { individual entities rather than part of a } \\
\text { community or a broader portfolio of structures }\end{array}$ & Yes & 1 \\
\hline 23 & $\begin{array}{l}\text { Portfolio/Multi- } \\
\text { Building Analysis }\end{array}$ & Lack of holistic regional planning & Yes & 1 \\
\hline 24 & $\begin{array}{l}\text { Fundamental } \\
\text { Analysis Tools }\end{array}$ & $\begin{array}{l}\text { Need standardized inputs for energy modeling } \\
\text { tools }\end{array}$ & Yes & 1 \\
\hline 25 & $\begin{array}{l}\text { Fundamental } \\
\text { Analysis Tools }\end{array}$ & $\begin{array}{l}\text { Complex modeling tools require specialized } \\
\text { expertise and are time-intensive }\end{array}$ & Yes & 4 \\
\hline 26 & $\begin{array}{l}\text { Fundamental } \\
\text { Analysis Tools }\end{array}$ & $\begin{array}{l}\text { Modeling tools often don't adequately } \\
\text { accommodate advanced technologies and } \\
\text { systems (such as daylighting controls) }\end{array}$ & Yes & 2 \\
\hline 27 & $\begin{array}{l}\text { Fundamental } \\
\text { Analysis Tools }\end{array}$ & $\begin{array}{l}\text { Better part-load performance data needed for } \\
\text { modeling HVAC equipment }\end{array}$ & Yes & 1 \\
\hline 28 & $\begin{array}{l}\text { Design and } \\
\text { Construction } \\
\text { Process }\end{array}$ & $\begin{array}{l}\text { Integrated design directed toward high } \\
\text { performance can be executed by a few leading } \\
\text { firms but is not the norm across the industry }\end{array}$ & Yes & 7 \\
\hline 29 & $\begin{array}{l}\text { Design and } \\
\text { Construction } \\
\text { Process }\end{array}$ & $\begin{array}{l}\text { Soft costs related to the design and construction } \\
\text { of high performance buildings are not well } \\
\text { understood }\end{array}$ & Yes & 1 \\
\hline 30 & $\begin{array}{l}\text { Design and } \\
\text { Construction } \\
\text { Process }\end{array}$ & $\begin{array}{l}\text { Capital budgets and operating budgets are set } \\
\text { and managed independently }\end{array}$ & Yes & 7 \\
\hline 31 & $\begin{array}{l}\text { Design and } \\
\text { Construction } \\
\text { Process }\end{array}$ & $\begin{array}{l}\text { Organizations often form teams that are too } \\
\text { small (often only a single energy champion), } \\
\text { and lack the resources or knowledge to be } \\
\text { successful }\end{array}$ & Yes & 1 \\
\hline
\end{tabular}




\begin{tabular}{|c|c|c|c|c|}
\hline 32 & $\begin{array}{l}\text { Design and } \\
\text { Construction } \\
\text { Process }\end{array}$ & $\begin{array}{l}\text { Lack of an energy manager or building operator } \\
\text { who is authorized to either make investments in } \\
\text { energy-efficient technologies or change } \\
\text { operational practices to save energy }\end{array}$ & No & 1 \\
\hline 33 & $\begin{array}{l}\text { Design and } \\
\text { Construction } \\
\text { Process }\end{array}$ & $\begin{array}{l}\text { The design, construction, and operation of } \\
\text { commercial buildings involve multiple parties } \\
\text { and their Incentives to invest in and implement } \\
\text { energy efficiency vary widely (e.g., split } \\
\text { incentives) }\end{array}$ & Yes & 7 \\
\hline 34 & $\begin{array}{l}\text { Design and } \\
\text { Construction } \\
\text { Process }\end{array}$ & $\begin{array}{l}\text { When construction changes are needed (for } \\
\text { scheduling or product availability), the solutions } \\
\text { are often not evaluated consistent with the } \\
\text { design goals and don't consider energy impacts }\end{array}$ & Yes & 1 \\
\hline 35 & $\begin{array}{l}\text { Strategy } \\
\text { Demonstration }\end{array}$ & $\begin{array}{l}\text { The industry lacks data about cost-effectiveness } \\
\text { of high-performance buildings that use leapfrog } \\
\text { technologies and design approaches }\end{array}$ & Yes & 6 \\
\hline 36 & $\begin{array}{l}\text { Life Cycle } \\
\text { Assessment }\end{array}$ & $\begin{array}{l}\text { The choice of whether an item is allocated to } \\
\text { the annual budget or capitalized can hinder or } \\
\text { promote the use of total cost of ownership } \\
\text { analysis }\end{array}$ & Yes & 1 \\
\hline 37 & $\begin{array}{l}\text { Life Cycle } \\
\text { Assessment }\end{array}$ & $\begin{array}{l}\text { Need for increased deployment of life cycle cost } \\
\text { analysis tools }\end{array}$ & Yes & 1 \\
\hline 38 & $\begin{array}{l}\text { Data Collection and } \\
\text { Dissemination }\end{array}$ & $\begin{array}{l}\text { Benchmark data of actual building performance } \\
\text { by building type and climate zone is very limited }\end{array}$ & Yes & 4 \\
\hline 39 & $\begin{array}{l}\text { Data Collection and } \\
\text { Dissemination }\end{array}$ & $\begin{array}{l}\text { Need better disclosure requirements for energy } \\
\text { performance data }\end{array}$ & Yes & 4 \\
\hline 40 & $\begin{array}{l}\text { Data Collection and } \\
\text { Dissemination }\end{array}$ & $\begin{array}{l}\text { Making all utility billing data accessible (in an } \\
\text { anonymous format) for various purposes of } \\
\text { measurement and analysis is not possible today }\end{array}$ & Yes & 1 \\
\hline 41 & $\begin{array}{l}\text { Education and } \\
\text { Training }\end{array}$ & $\begin{array}{l}\text { There is a lot of bad information in the field of } \\
\text { high-performance buildings due to over- } \\
\text { generalization of findings from past projects }\end{array}$ & Yes & 1 \\
\hline 42 & $\begin{array}{l}\text { Education and } \\
\text { Training }\end{array}$ & $\begin{array}{l}\text { Lack of policy package or "one-pagers" to give } \\
\text { to state legislatures describing the benefit of } \\
\text { NZE or high-performance buildings }\end{array}$ & Yes & 1 \\
\hline 43 & $\begin{array}{l}\text { Education and } \\
\text { Training }\end{array}$ & $\begin{array}{l}\text { Need for FAQ documents tailored to key } \\
\text { audiences }\end{array}$ & Yes & 1 \\
\hline 44 & $\begin{array}{l}\text { Education and } \\
\text { Training }\end{array}$ & $\begin{array}{l}\text { Building operator education and certification is } \\
\text { needed for ZNE buildings }\end{array}$ & Yes & 7 \\
\hline 45 & $\begin{array}{l}\text { Education and } \\
\text { Training }\end{array}$ & $\begin{array}{l}\text { There is not a sufficiently large number of local } \\
\text { and highly skilled professionals that are able to } \\
\text { guide a building project toward optimal energy } \\
\text { performance }\end{array}$ & Yes & 8 \\
\hline 46 & $\begin{array}{l}\text { Education and } \\
\text { Training }\end{array}$ & $\begin{array}{l}\text { Need for clarity and consensus on specific } \\
\text { workforce needs }\end{array}$ & Yes & 2 \\
\hline 47 & $\begin{array}{l}\text { Technology } \\
\text { Development }\end{array}$ & $\begin{array}{l}\text { Need for information on high-performance } \\
\text { pathways for key building systems }\end{array}$ & Yes & 1 \\
\hline 48 & $\begin{array}{l}\text { Technology } \\
\text { Development }\end{array}$ & $\begin{array}{l}\text { Need for smarter, predictive, and self-diagnostic } \\
\text { energy management systems }\end{array}$ & Yes & 3 \\
\hline 49 & $\begin{array}{l}\text { Technology } \\
\text { Development }\end{array}$ & $\begin{array}{l}\text { Daylighting is inherently complex and a number } \\
\text { of elements must be carefully integrated to } \\
\text { ensure savings }\end{array}$ & Yes & 2 \\
\hline
\end{tabular}




\begin{tabular}{|c|c|c|c|c|}
\hline 50 & $\begin{array}{l}\text { Technology } \\
\text { Development }\end{array}$ & $\begin{array}{l}\text { Getting beyond } 50 \% \text { savings requires } \\
\text { addressing plug and process loads, where there } \\
\text { is currently little research }\end{array}$ & Yes & 3 \\
\hline 51 & $\begin{array}{l}\text { Technology } \\
\text { Development }\end{array}$ & $\begin{array}{l}\text { A higher level of sensor and measurement } \\
\text { accuracy and reliability, especially the latent } \\
\text { component of the load, is needed. }\end{array}$ & Yes & 1 \\
\hline 52 & $\begin{array}{l}\text { Technology } \\
\text { Development }\end{array}$ & $\begin{array}{l}\text { There is a need for high-performance and cost- } \\
\text { effective building envelope commissioning } \\
\text { technologies }\end{array}$ & Yes & 1 \\
\hline 53 & $\begin{array}{l}\text { Technology } \\
\text { Development }\end{array}$ & $\begin{array}{l}\text { Better methods are needed for avoiding } \\
\text { systems working at cross-purposes to maintain } \\
\text { occupant comfort }\end{array}$ & Yes & 1 \\
\hline 54 & $\begin{array}{l}\text { Technology } \\
\text { Development }\end{array}$ & $\begin{array}{l}\text { Smaller capacity equipment that will be more } \\
\text { common in NZE buildings tend to have lower } \\
\text { efficiency }\end{array}$ & Yes & 1 \\
\hline 55 & $\begin{array}{l}\text { Energy } \\
\text { Performance Goals }\end{array}$ & $\begin{array}{l}\text { Separate targets are need for building types } \\
\text { that cannot achieve NZE using on-site } \\
\text { generation and those that are just very } \\
\text { challenging }\end{array}$ & Yes & 2 \\
\hline 56 & $\begin{array}{l}\text { Energy } \\
\text { Performance Goals }\end{array}$ & $\begin{array}{l}\text { The NZE movement can have the perverse } \\
\text { effect of encouraging urban sprawl given that } \\
\text { smaller one-story buildings are perceived to } \\
\text { achieve ZNE easier than large ones }\end{array}$ & Yes & 2 \\
\hline 57 & $\begin{array}{l}\text { Energy } \\
\text { Performance Goals }\end{array}$ & $\begin{array}{l}\text { Need to further refine the language or lexicon } \\
\text { used to discuss NZE }\end{array}$ & Yes & 2 \\
\hline 58 & $\begin{array}{l}\text { Energy } \\
\text { Performance Goals }\end{array}$ & $\begin{array}{l}\text { The marketplace needs clear summaries of the } \\
\text { conditions where NZE is most feasible }\end{array}$ & Yes & 1 \\
\hline 59 & $\begin{array}{l}\text { Energy } \\
\text { Performance Goals }\end{array}$ & $\begin{array}{l}\text { There are a limited number of political leaders } \\
\text { engaged in support of energy efficiency }\end{array}$ & No & 2 \\
\hline 60 & $\begin{array}{l}\text { Energy } \\
\text { Performance Goals }\end{array}$ & $\begin{array}{l}\text { The multitude of federal program initiatives for } \\
\text { commercial building energy efficiency- in } \\
\text { particular at DOE and EPA-can be a source of } \\
\text { confusion among building owners, operators, } \\
\text { and occupants }\end{array}$ & Yes & 1 \\
\hline 61 & $\begin{array}{l}\text { Energy } \\
\text { Performance } \\
\text { Assessment }\end{array}$ & $\begin{array}{l}\text { There is an overabundance of metrics being } \\
\text { used in too many different ways to allow for } \\
\text { easy benchmarking and comparisons }\end{array}$ & Yes & 3 \\
\hline 62 & $\begin{array}{l}\text { Building Operation } \\
\text { and Occupant } \\
\text { Behavior }\end{array}$ & $\begin{array}{l}\text { Most organizations do not know how to } \\
\text { convince occupants to change their behaviors }\end{array}$ & Yes & 1 \\
\hline 63 & $\begin{array}{l}\text { Building Operation } \\
\text { and Occupant } \\
\text { Behavior }\end{array}$ & $\begin{array}{l}\text { Buildings not operated in a way that achieves } \\
\text { intended performance }\end{array}$ & Yes & 8 \\
\hline 64 & $\begin{array}{l}\text { Building Operation } \\
\text { and Occupant } \\
\text { Behavior }\end{array}$ & $\begin{array}{l}\text { Energy cost impacts of specific behaviors and } \\
\text { operational practices are not well understood }\end{array}$ & Yes & 2 \\
\hline 65 & $\begin{array}{l}\text { Building Operation } \\
\text { and Occupant } \\
\text { Behavior }\end{array}$ & $\begin{array}{l}\text { Occupants who lease office space may not } \\
\text { understand their stake in energy performance }\end{array}$ & Yes & 3 \\
\hline 66 & Utilities & $\begin{array}{l}\text { Research is needed to examine how NZE } \\
\text { buildings impact the load profile of utilities }\end{array}$ & No & 2 \\
\hline 67 & Utilities & $\begin{array}{l}\text { Lack of state requirements for utilities to carry } \\
\text { out integrated resource planning, utilizing the } \\
\text { least-cost resource mix, including both supply } \\
\text { and demand-side options }\end{array}$ & No & 2 \\
\hline
\end{tabular}




\begin{tabular}{|c|l|l|c|c|}
\hline 68 & Utilities & $\begin{array}{l}\text { Utility rates do not fully decouple cost-recovery } \\
\text { from volumetric sales }\end{array}$ & No & 1 \\
\hline 69 & Utilities & $\begin{array}{l}\text { Some utilities do not see energy efficiency as a } \\
\text { significant strategy for managing resource } \\
\text { portfolios }\end{array}$ & No & 1 \\
\hline
\end{tabular}

